III) Nordic Council of Ministers

Making
the Switch

From fossil fuel subsidies to sustainable energy

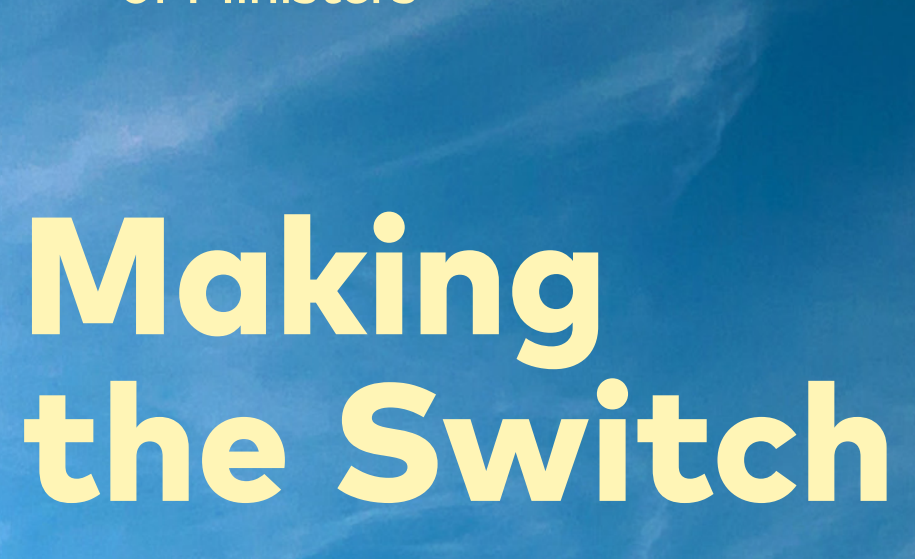
sustainable energy

37. 9.

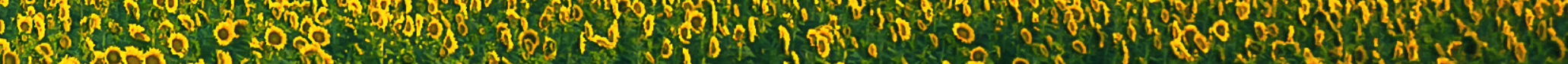

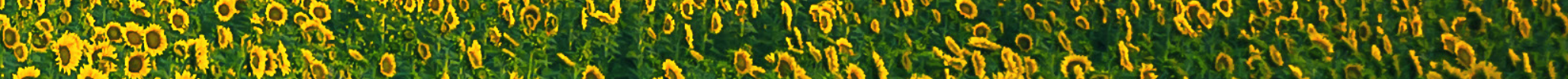

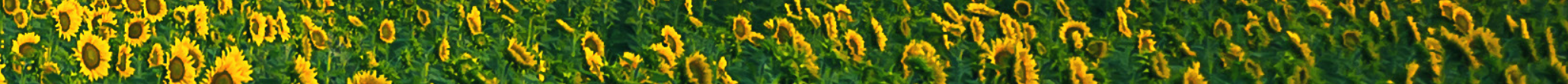

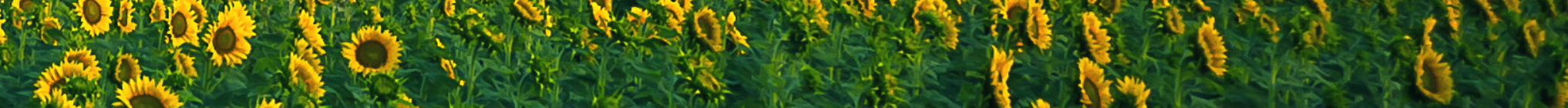

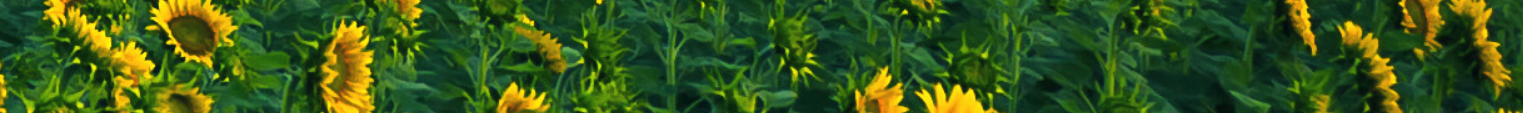

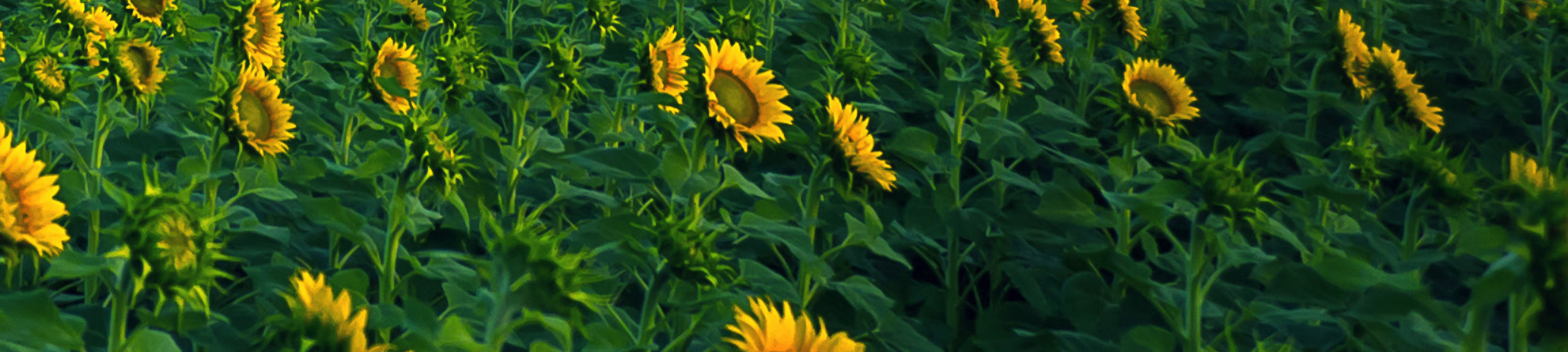





\section{Making the Switch}

From fossil fuel subsidies to sustainable energy

Laura Merrill, Richard Bridle, Markus Klimscheffskij, Paula Tommila, Lucky Lontoh, Shruti Sharma, Yanick Touchette, Phil Gass, Frédéric Gagnon-Lebrun, Lourdes Sanchez and Ivetta Gerasimchuk

TemaNord 2017:537 


\section{Making the Switch}

From fossil fuel subsidies to sustainable energy

Laura Merrill, Richard Bridle, Markus Klimscheffskij, Paula Tommila, Lucky Lontoh, Shruti Sharma,

Yanick Touchette, Phil Gass, Frédéric Gagnon-Lebrun, Lourdes Sanchez and Ivetta Gerasimchuk

ISBN 978-92-893-5016-7 (PRINT)

ISBN 978-92-893-5017-4 (PDF)

ISBN 978-92-893-5018-1 (EPUB)

http://dx.doi.org/10.6027/TN2017-537

TemaNord 2017:537

ISSN $0908-6692$

Standard: PDF/UA-1

ISO 14289-1

(c) Nordic Council of Ministers 2017

Layout: NMR

Cover photo: unsplash.com/Gustavo Quepón

Print: Rosendahls

Printed in Denmark

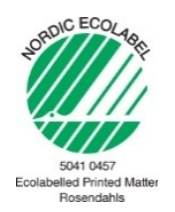

Although the Nordic Council of Ministers funded this publication, the contents do not necessarily reflect its views, policies or recommendations.

\section{Nordic co-operation}

Nordic co-operation is one of the world's most extensive forms of regional collaboration, involving Denmark, Finland, Iceland, Norway, Sweden, the Faroe Islands, Greenland, and Åland.

Nordic co-operation has firm traditions in politics, the economy, and culture. It plays an important role in European and international collaboration, and aims at creating a strong Nordic community in a strong Europe.

Nordic co-operation seeks to safeguard Nordic and regional interests and principles in the global community. Shared Nordic values help the region solidify its position as one of the world's most innovative and competitive. 


\section{Contents}

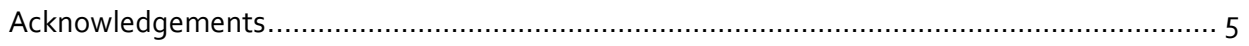

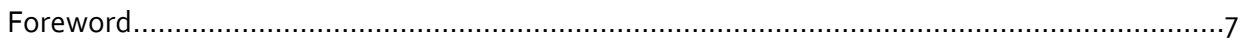

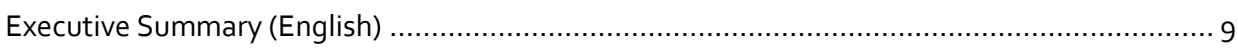

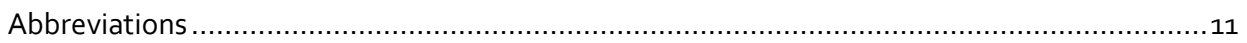

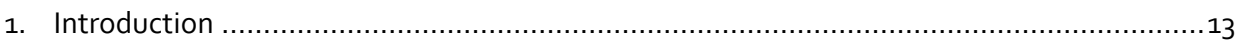

2. Fossil Fuel Subsidies and Sustainable Development ................................................15

$2.1 \quad$ The Size and Scale of Fossil Fuel Subsidies ..................................................

2.2 Fossil Fuel Subsidies and the Economy .................................................... 16

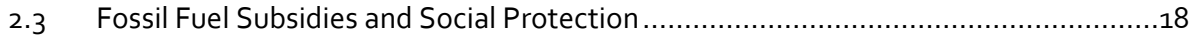

2.4 Fossil Fuel Subsidies and the Sustainable Development Goals ............................. 20

2.5 Fossil Fuel Subsidies and Air Pollution .......................................................... 22

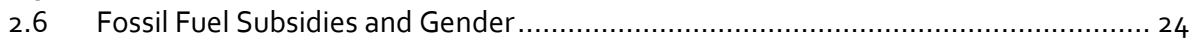

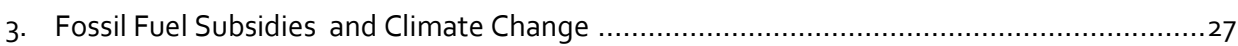

3.1 Removal of Consumption Fossil Fuel Subsidies and Reduced Emissions................. 28

3.2 SWAP Savings From Fossil Fuel Subsidy Reform Toward Zero Carbon Energy

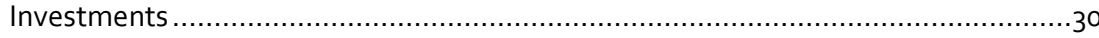

3.3 Removal of Upstream Producer Subsidies and Further Emissions Reductions ..........33

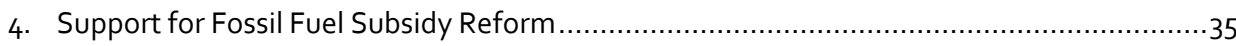

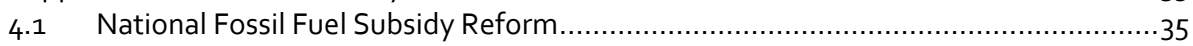

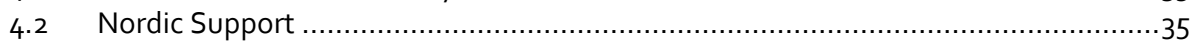

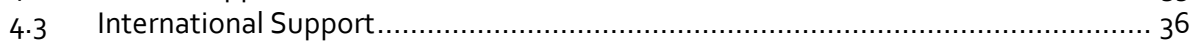

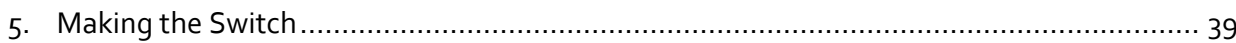

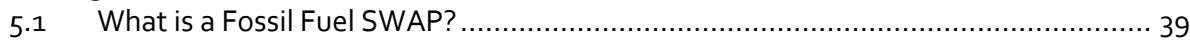

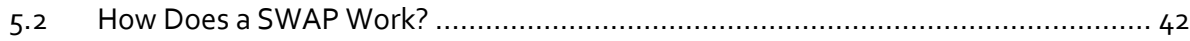

5.3 International Experience of Sustainable Energy Programs ................................ 42

5.4 Why Switch Old Subsidies for New Subsidies? ................................................ 44

5.5 Potential Funders and International Support ............................................... 45

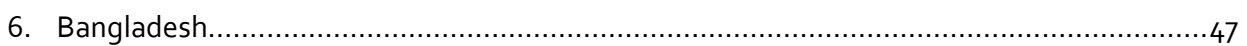

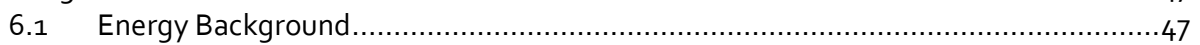

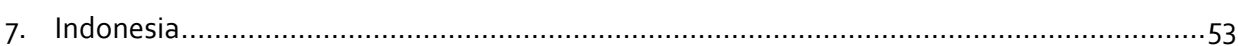

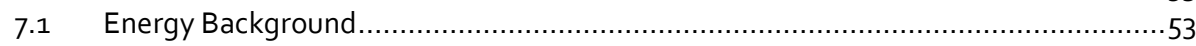

7.2 Swapping LPG Subsidies for Increased Investments in the Social Safety Net ..........55

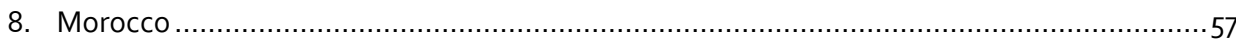

8.1 Current Energy Mix and Government Energy Plans ..................................... 57

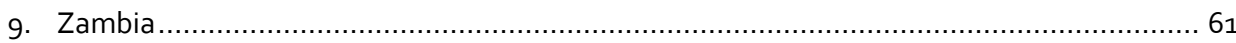

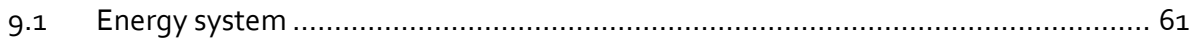

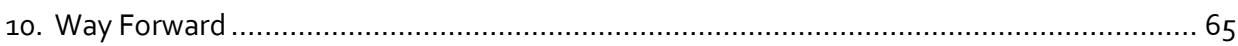

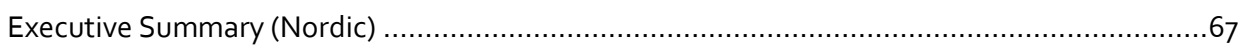

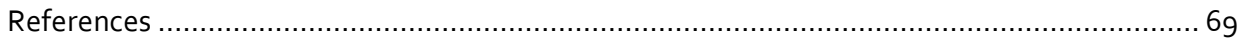




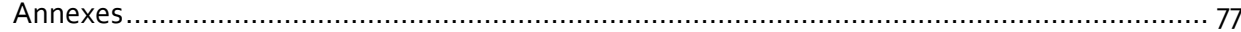

Annex 1. Comparison of Global Figures for Fossil Fuel Subsidies Estimates ...................... 77

Annex 2. Likely Impacts on Poor Women of Fossil Fuel Subsidies, Their Reform and

Mitigation Measures ......................................................................... 78

Annex 3. Emissions Reductions Scenarios from Removal of Fossil Fuel Subsidies, existing research 


\section{Acknowledgements}

This report was written by researchers and associates working at and for the Global Subsidies Initiative of the International Institute for Sustainable Development (IISD) (www.iisd.org/gsi) and from Gaia Consulting (www.gaia.fi).

We would like to acknowledge and thank the following people for reviewing this report: Lucy Kitson, Richard Bridle, Harro Van Asselt, Jan-Petter Boring, Malena Sell, Paula Tommila, Hans Jakob Erikson, Anna Laitinen, Abdelali Dakkina, L.L. Chinjenge and Ivetta Gerasimchuk.

This report does not reflect the views of the Nordic Council of Ministers. Any mistakes are the responsibility of the authors. 



\section{Foreword}

This report estimates current global subsidies to both consumers and producers of fossil fuels to be approximately USD 425 billion in 2015 . The benefits go mainly to richer urban households. Removing these subsidies will bring about not only emissions reductions, but also free up domestic resources to invest elsewhere. Systemic subsidization of fossil fuels by governments restrains sustainable development: economically, socially, for women, for health and education, for clean air, and finally from reductions in carbon emissions. Huge opportunities to invest these resources more productively are lost every year because of such subsidies. A number of governments have made progress in phasing subsidies out, while in other countries they still persist.

Subsidies to fossil fuels work against the purpose of the 2015 Paris Agreement. Its targets relate to holding temperature increase to below $2^{\circ} \mathrm{C}$ and $1.5^{\circ} \mathrm{C}$. However, the imminent global peaking of emissions points to the need to switch off the subsidies to fossil fuel producers and consumers. Instead, governments should facilitate a switch to massive investments into renewables and other low- or noemission technologies. Savings from reduced consumer and producer subsidies can be used for large-scale renewables, energy efficiency and public transport systems, and, in developing countries, toward the rural poor, through for instance cleaner cooking and lighting such as distributed renewables and clean cook stoves. Savings can also be channelled to building resilience of countries that will be hardest hit by climate change.

The Global Subsidies Initiative (GSI) of the International Institute for Sustainable Development (IISD) together with Gaia Consulting brings a rich diversity of perspectives. This study is carried out for NOAK, a working group under the Nordic Council of Ministers. The aim of NOAK is to contribute to an ambitious and effective implementation of the United Nations Framework Convention on Climate Change (UNFCCC) and its Paris Agreement, with a Nordic perspective. To this end, the group prepares studies and reports, conducts meetings and organizes conferences supporting Nordic and international negotiators in the UN climate negotiations.

April 2017, Oslo

Peer Stiansen

Chair of the Nordic Working Group for

Global Climate Negotiations (NOAK) 



\section{Executive Summary (English)}

We are at a point when we need better, fairer, smarter and cleaner government policies to build energy systems to rapidly redirect us toward zero emissions pathways. This report details why and how current global government subsidies to consumers and producers of fossil fuels - of around USD 425 billion in 2015 - hold us back from delivering sustainable development and building the sustainable energy systems needed in the 21st Century. Subsidies to fossil fuels represent massive and ongoing lost opportunities for governments to support the delivery of the Sustainable Development Goals: representing half the amount needed to plug the sustainable energy access finance gap; 11 times more than needed for the basic education finance gap; 13 times more than the basic health care gap; three times more than the equivalent subsidies to renewables; and a massive 22 times more than current financing toward adaptation and resilience to climate change. This report outlines how fossil fuel subsidies are a cost that governments can no longer afford to ignore from many perspectives, including economic, social protection and welfare; health care; education; air pollution; and gender.

Fossil fuel subsidies also contribute toward climate change by depressing the price of fossil fuels and thereby encouraging greater production and consumption - and thus carbon emissions. Research estimates that the removal of all fossil fuel subsidies would lead to a global decrease in carbon emissions of between 6.4-8.2 per cent by 2050 . Country-level research undertaken for the Nordic Council of Ministers across 20 countries prior to the Paris Agreement found a national average of 11 per cent reduction by 2020 , rising to an average 18 per cent reduction combined with a SWAP of 30 per cent of savings toward renewable energy and energy efficiency. It is estimated that with the combination of fiscal instruments applied to fossil fuels (i.e., subsidy reform and appropriate taxation) global emissions reductions could improve further still to a 20 per cent reduction. Data over the last 30 years suggests that, had we switched off government subsidies to fossil fuels, global emissions would have been more than a third lower than they actually were in 2010.

Therefore, this report outlines how governments need to switch off subsidies to oil, gas and coal, but also need to switch on massive investments into renewables and energy efficiency and other more productive investments such as targeted cash safety nets for the poor or for health and education. Countries need to make a SWAP. Nordic countries have started this shift away from fossil fuel subsidies and toward government support to heat pumps as in Sweden, electric cars as in Norway and wind power in Denmark. A SWAP is where countries undergo fossil fuel subsidy reform and allocate some of the resulting savings toward sustainable energy and development. It is a huge and desperately needed idea in an age of scarce resources and a planet undergoing climate change. One example would be gradual removal of diesel subsidies with a parallel investment into solar agriculture pumps that can replace expensive diesel ones; 
a removal of gas subsidies alongside a huge investment into industrial energy efficiency; reform of coal subsidies with a shift of savings and support toward renewable energy; or a removal of gasoline subsidies and investment in building targeted national safety net schemes. Countries such as Ethiopia, The Philippines, Peru, and Morocco have started to make this shift. This report outlines SWAPs for four countries that are all currently undergoing reform: Bangladesh, Indonesia, Morocco and Zambia. Such a SWAP is needed for all economies, and SWAP suggestions for China and the United States are also included with a focus of savings moved toward a just transition and energy efficiency.

The 2015 Paris Agreement was an important signal to everyone. However, the work of implementing large-scale government reforms and a parallel redirection toward zero carbon and sustainable energy infrastructure projects is now needed - a massive switching off of fossil fuels subsidies and a switching on of government policies to support renewables and energy efficiency. A global SWAP. A global shift. All of us need to make the SWAP and make it soon. 


\section{Abbreviations}

\begin{tabular}{|c|c|}
\hline ADB & Asian Development Bank \\
\hline AfDB & African Development Bank \\
\hline APEC & Asia-Pacific Economic Cooperation \\
\hline BAU & Business as usual \\
\hline CNG & Compressed natural gas \\
\hline CUTS & Consumer Unity and Trust Society \\
\hline DANIDA & Danish International Development Agency \\
\hline ESMAP & Energy Sector Management Assistance Program \\
\hline GCF & Green Climate Fund \\
\hline GED & General Economics Division \\
\hline GIZ & Deutsche Gesellschaft für Internationale Zusammenarbeit \\
\hline GSI & Global Subsidies Initiative \\
\hline GST & Goods and Services Tax \\
\hline IBRD & International Bank for Reconstruction and Development \\
\hline ICCG & International Centre for Climate Governance \\
\hline ICMM & International Council on Mining and Metals \\
\hline IEA & International Energy Agency \\
\hline IFAD & International Fund for Agricultural Development \\
\hline IFC & International Finance Corporation \\
\hline IISD & International Institute for Sustainable Development \\
\hline IMF & International Monetary Fund \\
\hline INDC & Intended Nationally Determined Contributions \\
\hline IPCC & Intergovernmental Panel on Climate Change \\
\hline IRENA & International Renewable Energy Agency \\
\hline KfW & Kreditanstalt für Wiederaufbau \\
\hline LPG & Liquefied petroleum gas \\
\hline NAMA & Nationally Appropriate Mitigation Action \\
\hline NCF & Nordic Climate Facility \\
\hline NCM & Nordic Council of Ministers \\
\hline NDC & Nationally Determined Contribution \\
\hline NDF & Nordic Development Fund \\
\hline NSSS & National Social Security Strategy \\
\hline $\mathrm{OCl}$ & Oil Change International \\
\hline ODA & Official Development Aid \\
\hline ODI & Overseas Development Institute \\
\hline OECD & Organisation for Economic Co-operation and Development \\
\hline PSF & Private Sector Facility \\
\hline SADC & Southern African Development Community \\
\hline
\end{tabular}




$\begin{array}{ll}\text { SDG } & \text { Sustainable Development Goals } \\ \text { SEI } & \text { Sustainable Energy Investments } \\ \text { SREDA } & \text { Sustainable and Renewable Energy Development Authority } \\ \text { UNDP } & \text { United Nations Development Programme } \\ \text { UNEP } & \text { United Nations Environment Programme } \\ \text { UNESCO } & \text { United Nations Educational, Scientific and Cultural Organization } \\ \text { UNFCCC } & \text { United Nations Framework Convention on Climate Change } \\ \text { UNIDO } & \text { United Nations Industrial Development Organization } \\ \text { VAT } & \text { Value Added Taxation } \\ \text { WFP } & \text { World Food Program } \\ \text { WHO } & \text { World Health Organization }\end{array}$




\section{Introduction}

This report brings together findings from work on fossil fuel subsidy reform supported by the Nordic Council of Ministers (NCM) Prime Ministers Initiative and the Nordic Environmental Action Plan 2013-2018 (Norden, 2012). The initiative and plan provided a mandate for Nordic countries to work together on both fossil fuel subsidy reform and linking up environment and climate change work within development aid programs. The Global Subsidies Initiative (GSI) of the International Institute for Sustainable Development (IISD) worked with the NCM on a number of projects. For example, in 2015 the GSI-Integrated Fiscal (GSI-IF) model was developed to evaluate the impact of fossil fuel subsidy reform on greenhouse gas emissions: it was applied to 20 countries within the United Nations Framework Convention on Climate Change (UNFCCC) to enable a better country-level understanding of the link between fossil fuel subsidies and climate change (see Figure 5) (Merrill, Harris, Casier, \& Bassi, 2015; Merrill, Bassi, Bridle, \& Christensen, 2015). The information was shared with UNFCCC country negotiators through policy briefs and publications and side events. Ultimately, 14 countries included the issue of fossil fuel subsidy or energy sector reform within their Nationally Determined Contributions (NDC) (Terton, Gass, Merrill, Wagner, \& Meyer, 2015). A UNFCCC Technical Experts Meeting also covered the issue briefly - technical papers prepared by the Secretariat have also pointed to the issue. Many more countries and thousands of businesses supported an international Communique to raise the issue up the agenda prior to the Paris Agreement (Friends of Fossil Fuel Subsidy Reform, n.d.). Since Paris, the focus has been on implementation and early action. A brochure detailing examples of countries (Ethiopia, Peru, Philippines) that have reformed subsidies and invested in sustainable energy was shared at the UNFCCC Marrakech meetings in 2016 (Merrill, Christensen \& Sanchez, 2016). This report gives more details for specific countries to switch away from fossil fuel subsidies and to swap savings toward renewable energy and energy efficiency. Potential future SWAPs between fossil fuel subsidies and sustainable energy are provided for Bangladesh, Indonesia, Morocco and Zambia. These countries were identified based on a process of prioritizing developing and emerging economies with significant subsidies, in the process of (or facing) reform and to whom support could be directed.

This report starts by detailing the current size of fossil fuel subsidies and the overall links between fossil fuel subsidies and sustainable development, including: the links to the economy; society and social protection schemes; financing the Sustainable Development Goals (SDGs) including health, education and sustainable energy for all; to air pollution; gender; and finally climate change. It then details support that has been lent to the issue domestically and internationally from the Nordic countries and more broadly from other organizations and venues. The final section explains the SWAP concept for switching away from fossil fuels and swapping savings toward sustainable 
energy and proposes potential SWAPs for a number of countries with outlines for Bangladesh, Indonesia, Morocco and Zambia. Lastly it is suggested that all countries could make such a SWAP between fossil fuel subsidies and toward sustainable energy investments for the future. 


\section{Fossil Fuel Subsidies and Sustainable Development}

\subsection{The Size and Scale of Fossil Fuel Subsidies}

Despite recent low oil prices, fossil fuel subsidies are still significant. In 2015, the IEA estimated that fossil fuel subsidies stood at USD 325 billion dollars for consumer subsidies alone (International Energy Agency [IEA], 2016). Subsidies to producers from G2O countries alone stand at 70 billion (Bast, Doukas, Pickard, van der Burg, \& Whitley, 2015). The Organisation for Economic Co-operation and Development (OECD) estimates the overall value of government support to fossil fuels at between USD 160-200 billion annually across 2010-2014 in OECD countries and including Brazil, China, India, Indonesia, Russia and South Africa. According to the OECD, the production or consumption of fossil fuels is supported by almost 800 individual policies (OECD, 2015). There is no estimate for the combined size of both downstream consumer and upstream producer subsidies, due to the opaque nature of producer subsidies and the painstaking work involved in identifying and tracking them. In terms of the way fossil fuel subsidies are measured Annex 1 gives an outline of the different methods employed (GSI, IEA, World Bank, OECD and International Monetary Fund [IMF], 2014). For the most part, measurements of fossil fuel subsidies focus on direct fiscal incentives. Indeed, GSI defines fossil fuel subsidies on the basis of the World Trade Organization Agreement on Subsidies and Countervailing Measures (WTO ASCM), Article 1.1. GSI measures subsidies based on an inventory approach interpreted from WTO ASCM of around 30 energy subsidy types. A reasonable estimate places the combined total for both producer and consumer subsidies for 2015 at around USD 425 billion.

Most consumer fossil fuel subsidies are found in the Middle East. The IEA state that the largest sources of consumer subsidies to fossil fuels are Iran (16 per cent of the total, or USD 52 billion), Saudi Arabia (USD 49 billion), Russia (USD 30 billion) and Venezuela (USD 20 billion) (IEA, 2016c). In terms of environmental damage, in 2010 China, the former Soviet Union and the United States accounted for roughly 75 per cent of environmental costs associated with fossil fuel subsidies (Stefanski, 2016, p.29). Changes in the size of fossil fuel subsidies reflect changes in the price of oil, which is volatile. Importing country governments must pay more for fossil fuels when the price is high, and therefore subsidies increase. Reforms are difficult because prices may increase sharply. The current low oil price means the size of consumer fossil fuel subsidies are consequently lower. It is therefore easier for countries that import fossil fuels to reform their consumer subsidies in that there are lower pass-through costs to consumers. In 2015 and 2016 around 50 countries underwent some sort of reform (see Figure 8). Indeed, the IEA points out that "without the reforms adopted since 2009, the value of fossil fuel subsidies would 
have been $24 \%$ higher ( $\$ 117$ billion), putting the level of these subsidies at $\$ 610$ billion in 2014" (IEA, 2015b, p.96). Active reform combined with the lower oil price has helped lead to a reduction in consumer subsidies in recent years.

However, with low oil prices pressure builds on countries that export fossil fuels and maintain subsidies to domestic consumers. They, too, can no longer maintain such subsidies, and the last few years have seen significant reforms from countries like the United Arab Emirates and Saudi Arabia. In contrast, there are examples of increased pressure on governments to provide more subsidies upstream to fossil fuel producers in times of a low oil price (Gerasimchuk et al., 2017).

It is unclear whether reforms to date have structurally eliminated fossil fuel subsidies or if they will return when oil prices rise. Even where mechanisms are in place to automatically pass through future price increases, political pressure may force policy-makers to reintroduce subsidies. Properly structured reforms - with entrenched, transparent pricing mechanisms and additional appropriate taxation levels - will help prevent the return of fossil fuel subsidies in the presence of high oil prices.

"With the present magnitude of subsidies in favour of fossil fuels we are not on a viable pathway either economically, nor climatic wise. In essence, undertaking fossil fuel reforms is about spending money wisely and getting energy pricing right. This has been the core in the middle of Denmark's successful experience in promoting energy efficiency and renewable energy." Lars Løkke Rasmussen, Prime Minister of Denmark, (Paris 30 November 2015).

\subsection{Fossil Fuel Subsidies and the Economy}

The scale of subsidies means that they can occupy a large proportion of government budgets, especially in times of high oil prices. Thus, their removal can lead to substantial fiscal savings and free up resources for governments to invest in sectors such as health, education and sustainable energy for all. Ebeke and Ngouana $(2015$, p. 1) point out that "public expenditures in education and health were on average lower by o. 6 percentage point of GDP in countries where energy subsidies were 1 percentage point of GDP higher." Research from the IMF finds that reform and accurate taxation of fossil fuels could provide an average revenue stream to governments of around 2.6 per cent of GDP globally (Parry, Heine, Lis \& Li, 2014). Furthermore, the economic distortion from transport fuel subsidies has been estimated to amount to USD 44 billion of deadweight loss (2012) where the buyer's willingness to pay is below the opportunity cost across 10 countries with the highest subsidies (Davis, 2013). Furthermore, a review of 37 countries found "that fossil fuel subsidies, coal subsidies, electricity and natural gas subsidies have negative and significant impact toward growth" (Sulistiowati, 2015, p. viii). 
"Climate change is arguably the world's most critical contemporary market failure. It has significant consequences for people, the planet and the profitability of a broad range of companies - including insurers. Fossil fuel subsidies fan the flames of this market failure. We believe the subsidies should be phased out as soon as possible. We are proud supporters of the Fossil Fuel Subsidy Reform Communiqué." - Mark Wilson, Group Chief Executive Officer, Aviva, on supporting the Communiqué.

Reforming subsidies to fossil fuels unlocks savings to governments. Recently, Indonesia was able to free up around 10 per cent of state expenditure (USD 15.6 billion) through a combination of fossil fuel subsidy reforms (largely removing significant gasoline and diesel subsidies) and falling world oil prices (Pradiptyo, Susamto, Wirotomo, Adisasmita, \& Beaton, 2016). Pricing reforms in India, mainly to gasoline (2010) and diesel (2014) have cut the country's subsidies bill in 2014 by USD 15 billion (IEA, 2015b), while subsidy reforms have led to the parallel implementation of one of the largest cash transfer programs in the world.

Not only are significant portions of government budgets ring-fenced for government subsidies crowding out investment in other areas of the economy, but fossil fuel subsidies are also associated with weaker institutions. Their reform can be a step toward strengthening institutions to deliver targeted social welfare and tax systems. There are strong links between countries that have energy resources and the presence of subsidies, and particularly so for oil. There are clear, negative associations between subsidies to GDP and a measure of government effectiveness, rule of law, regulatory quality and freedom from corruption (Commander, 2012).

GSI research suggests that fossil fuel subsidies can also act as a barrier to the development and deployment of renewable energy technologies. Bridle and Kitson (2014) identified three impacts of the presence of fossil fuel subsidies on renewable electricity generation. First, subsidies reduce the costs of fossil fuel-powered electricity generation and thereby impair the cost competitiveness of renewable energy. Second, they create an incumbent advantage that reinforces the position of fossil fuels within the electricity system. Finally, subsidies create conditions that favour investments in fossil fuel-based technologies over renewable alternatives.

"The world is now adding more renewable energy generating capacity than non-renewable; nonOECD countries are investing more in clean energy than OECD countries, with China alone accounting for more than $\$ 100$ billion annually; Germany and California produce more than 30 per cent of their electricity from renewable sources, the U.K. more than 20 per cent, Denmark more than 40 per cent from wind alone; the number-one selling 'large luxury' car in the U.S. is the Tesla S. This is what phase change looks like." Michael Bloomberg Chairman of the Advisory Board, Bloomberg New Energy Finance (January 2016) 


\subsection{Fossil Fuel Subsidies and Social Protection}

Fossil fuel subsidies do a poor job of assisting the poor effectively. Research covering 35 countries finds that "on average, the top income quintile receives more than six times more in total subsidies than the bottom quintile" (Coady, Flamini \& Sears, 2015, p. 12, see Figure 1) and that fossil fuel subsidies are very regressive: "nearly 93 out of every 100 dollars of gasoline subsidy 'leaks' to the top three quintiles." Subsidies to gasoline perform badly, the bottom two quintiles receive on average 7.4 per cent of benefits and the top two quintiles receive on average 83.2 per cent of benefits (Coady, Flamini \& Sears, 2015). Country data is also striking. Even with kerosene, where the IMF study finds that benefits are equally distributed across the quintiles, national surveys find real variations on the ground. One study in India finds that for every six rupees the government spends on kerosene subsidies only one rupee reaches the poorest 20 per cent of consumers (Clarke, 2014). This substantial leakage of subsidy benefits to the top income groups means that blanket fuel subsidies are an extremely costly and thus inefficient way to providing assumed targeted welfare to poor households.

Figure 1: Distribution of Subsidy Benefit by Income Group, \% of total subsidy benefit, across all fuel types

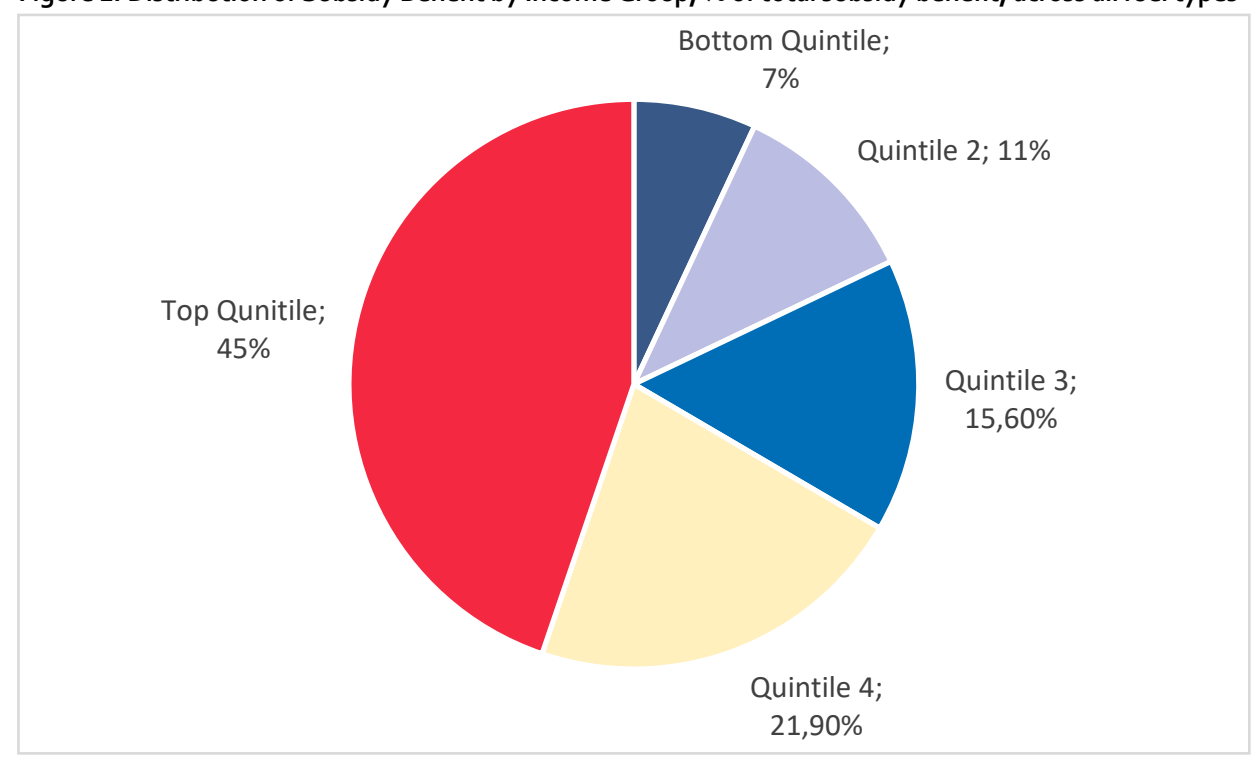

Source: Coady et al. 2015.

"While impressive progress is being made in some parts of the world to phase out fossil fuel subsidies, they remain stubbornly persistent: based on our latest estimate they amounted to almost USD 500 billion last year. Fossil fuel subsidies encourage wasteful consumption of finite resources with very detrimental economic and environmental consequences. To make matters worse, the benefits mainly go to richer households as they consume more energy: only $8 \%$ of the money spent typically reaches the poorest $20 \%$ of the population. I am convinced that subsidy reform can and should be a key pillar of a comprehensive strategy that can lead to a near-term peak in energy-related GHG emissions. I 
therefore endorse the Fossil Fuel Subsidy Reform Communique to Paris COP 21 and I commend this initiative to others." - Dr. Fatih Birol, Executive Director, IEA (1 Oct 2015).

The last few years have seen impressive progress by a number of governments in phasing out fossil fuel subsidies and investing instead in social safety nets, education, health care and development priorities. To mitigate the impact of gasoline and diesel subsidy reforms, Indonesia used a basket of social protection policies covering education, health insurance, food subsidies, cash transfers and infrastructure programs. Indeed, Indonesia's first large-scale unconditional cash transfer system was created in only six months in order to compensate for subsidy reforms. Brazil started to gradually increase prices on fossil fuels in the early 1990 s with deregulation in 2002 across gasoline, diesel and liquefied petroleum gas (LPG). From 2001 onwards Brazil developed better-targeted LPG voucher subsidies and a national conditional cash transfer scheme aimed at covering education and energy outcomes (Adeoti, Chete, Beaton, \& Clarke, 2016). Ghana reformed subsidies to gasoline and diesel: it also developed a livelihoods program to support families. India put in place a direct benefit transfer for LPG, which has since become one of the largest cash transfer programs in the world (Adeoti, et al., 2016). Morocco expanded a national conditional cash transfer, education and health insurance scheme at the same time as reforming (Merrill et al., 2016). The Philippines used targeted cash transfers to help build a national safety net and lifeline tariffs to protect the poor in the process of reforms (Mendoza, 2014). Peru expanded a conditional cash transfer program and introduced an improved cook stove distribution scheme (Merrill et al., 2016).

"We are all going to have to get rid of things which are frankly inefficient from the perspective of protecting the poor, from the perspective of growing, and from the perspective of decarbonizing. And the answer to all of that is fossil fuel subsidy reform" - Rachel Kyte, former Vice President and special Envoy Climate Change at the World Bank and current CEO SE4AIl. Speech at IISD Side Event at UN Climate Change Conference COP 20, Lima 2014

Reform presents an opportunity for governments to switch from relatively simple and easy-to-administer subsidies designed to provide welfare benefits via cheap fossil fuels toward more administratively complex, but better-targeted (and often cheaper) social welfare systems and safety nets via direct cash payments and targeted measures.

A World Bank report (Inchauste \& Victor, 2017 p.9) finds that the link between reforms and the development of social protection schemes is important in that "improvements in social protection systems are critical to the success of reforms" because they make it possible to target assistance to those most in need. Furthermore, it finds that a switch away from fossil fuel subsidies and toward better-targeted assistance can also promote better tracking and governance of the subsidies via smart cards or micropayment schemes. 


\subsection{Fossil Fuel Subsidies and the Sustainable Development Goals}

The Sustainable Development Goals (SDGs), which replace the Millennium Development Goals, were agreed in 2015. There are 17 goals, backed by 230 indicators (UNSTATS, 2016). Fossil Fuel Subsidy reform is included as a Means of Implementation within the SDGs under Goal 12: Sustainable Production and Consumption. It is one Means of Implementation within the SDGs that could actually help fund the scale of investment and increased domestic resources needed to deliver other SDGs. If this were also coupled with correct pricing of fossil fuels via taxation, the potential combined savings and ongoing revenue streams to governments are significant. The IMF estimates that removing subsidies and then taxing fossil fuels effectively represents an average potential revenue to governments of 2.6 per cent of GDP globally (Parry et al., 2014). Corrective taxes could be a significant revenue sources for many countries, and an increase in price leads to behavioural change. Many countries could experience significant revenue gains from either removal of subsidies and/or correct taxation of fossil fuels including Brazil, China, Egypt, Indonesia, Japan, Mexico, Nigeria, and the United States (Parry et al., 2014). Such revenues to governments could be better spent on other sectors of the economy, such as those reflected in the SDGs including health, education, infrastructure, and sustainable energy for all (Table 1 gives an indication of the scale of subsidies in comparison to existing financing gaps, while Figure 2 gives a comparison against health and education spending).

Table 1: Mind the Gap: Fossil Fuel Subsidies Could Fill the SDG Financing Gap

\begin{tabular}{|c|c|}
\hline $\begin{array}{l}\text { Energy Access around } 1 / 2 \text { the } \\
\text { gap }\end{array}$ & $\begin{array}{l}\text { Fossil fuel subsidies represent just under half of the budget needed to fund the clean } \\
\text { energy transition. Achieving universal energy access, doubling the share of renewable } \\
\text { energy in the global energy mix, and doubling the rate of improvement in energy } \\
\text { efficiency by } 2030 \text { is estimated to cost USD } 1 \text { trillion annually (SE4all, 2016)- savings } \\
\text { from subsidies to fossil fuels could help fund this transition. }\end{array}$ \\
\hline $\begin{array}{l}\text { Education: Fossil fuel } \\
\text { subsidies } 11 \text { times more than } \\
\text { the gap }\end{array}$ & $\begin{array}{l}\text { Globally annual subsidies to fossil fuels are almost } 11 \text { times larger than the funding } \\
\text { needed to plug the financing gap for universal education (USD } 39 \text { billion) (United } \\
\text { Nations Educational, Scientific and Cultural Organization [UNESCO], 2015). }\end{array}$ \\
\hline $\begin{array}{l}\text { Health: Fossil fuel subsidies } \\
13 \text { times more than the gap }\end{array}$ & $\begin{array}{l}\text { Fossil fuel subsidies are almost } 13 \text { times larger than the gap of USD } 33.3 \text { billion (2015) } \\
\text { needed to finance health care (reproductive, maternal, new-born, child and adolescent } \\
\text { health) (Global Financing Facility (2017). }\end{array}$ \\
\hline $\begin{array}{l}\text { Climate Change Adaptation } \\
\text { and Resilience: Fossil fuel } \\
\text { subsidies } 22 \text { times more } \\
\text { than current financing }\end{array}$ & $\begin{array}{l}\text { Fossil fuel subsidies represent around } 22 \text { times more than } 2014 \text { financing of USD } 22.5 \\
\text { billion (Merrill, 2016). By } 2050 \text { the gap is estimated to be huge at between USD } 280-500 \\
\text { billion. (United Nations Environment Programme [UNEP], 2016). }\end{array}$ \\
\hline $\begin{array}{l}\text { Climate Finance: Fossil fuel } \\
\text { subsidies are } 6 \text { times larger } \\
\text { than the gap to reach the } \\
\text { Paris pledge }\end{array}$ & $\begin{array}{l}\text { The Paris Agreement (2015) included agreement to mobilize USD } 100 \text { billion in climate } \\
\text { finance every year up to 2025. The current financing gap is estimated at USD } 70 \text { billion } \\
\text { in } 2015 \text { (World Bank, 2015a). Annual fossil fuel subsidies are currently } 6 \text { times larger } \\
\text { than this gap. }\end{array}$ \\
\hline $\begin{array}{l}\text { Renewables: } 3 \text { times higher } \\
\text { than renewable energy } \\
\text { subsidies in } 2014\end{array}$ & $\begin{array}{l}\text { Consumption subsidies of almost USD } 500 \text { billion were more than three times higher } \\
\text { than renewables subsidies of some USD } 140 \text { billion (consisting of USD } 114 \text { billion for } \\
\text { non-hydro renewables for power generation and USD } 24 \text { billion for other sectors, } \\
\text { notably biofuels) (IEA, 2016c). }\end{array}$ \\
\hline
\end{tabular}


By tackling subsidies governments are able to save resources and potentially allocate them elsewhere (health, education and sustainable energy). Governments may also tax fossil fuels effectively to bring in ongoing revenues.

"These subsidies contribute to the inefficient use of fossil fuels, undermine the development of energy-efficient technologies, act as a drag on clean, green energy deployment and in many developing countries do little to assist the poorest of the poor in the first place. The huge sums involved globally could be better spent on schools, health care, renewable energies and building resilient societies. The current, very low oil prices are a good opportunity to really get going on this issue." - Christiana Figueres, Executive Secretary of the UN Framework Convention on Climate Change (UNFCCC), On accepting the Communiqué, 3oth November 2015.

Figure 2: Fossil fuel Subsidies, Health and Education (\% of Government Expenditure), 2011

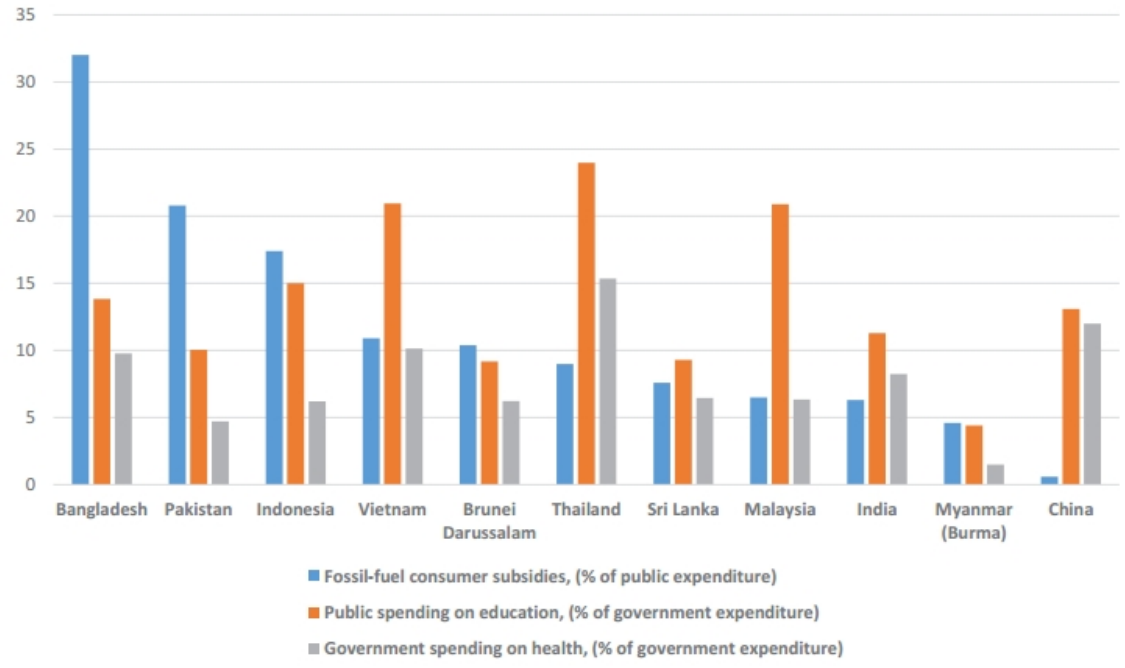

Source: Merrill, L., \& Chung, V. 2014. 
Figure 3: Fossil Fuel Subsidies and Energy Access

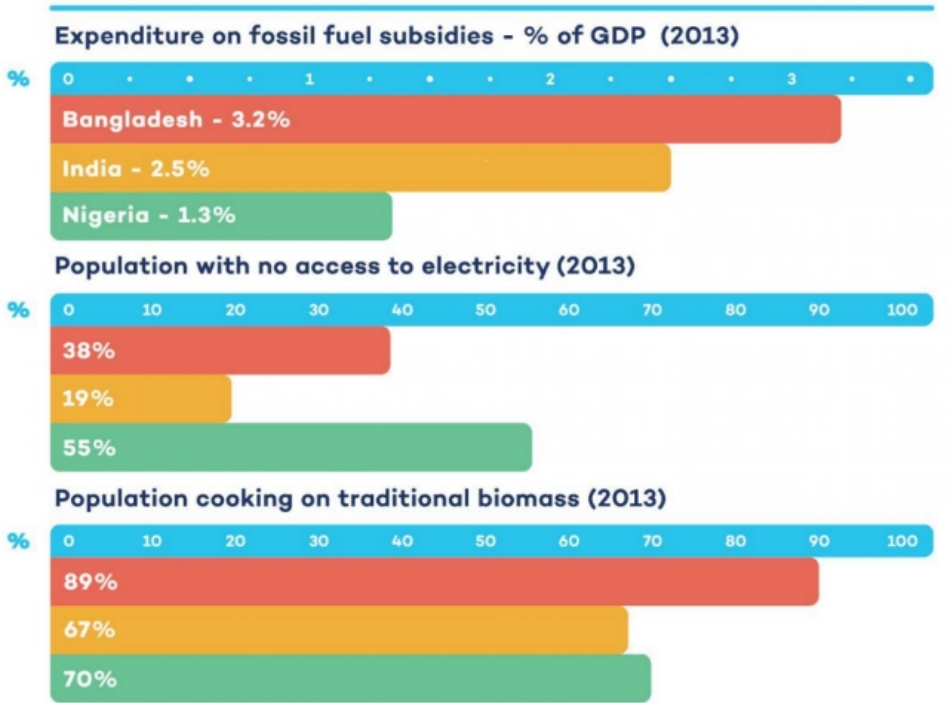

Source: This report based on data from Kitson et al. 2016 (p.2) and IEA database 2014.

\subsection{Fossil Fuel Subsidies and Air Pollution}

On a global scale, the removal of consumer fossil fuel subsidies (the vast majority of which by value are found within transport fuels diesel and petrol) would have positive health impacts. One estimate suggests that removing only consumer subsidies and taxing fossil fuels effectively could "cut global $\mathrm{CO}_{2}$ emissions by more than 20 per cent, and cut premature air pollution deaths by more than half" see Figure 4 (Coady, Parry, Sears, \& Shang, 2015, p. 7). Indeed, this research suggests that a combination of for fossil fuel subsidy reform and appropriate taxation of fossil fuels could reduce worldwide deaths from outdoor air pollution by 63 per cent.

Yet the link between fossil fuel subsidies and air pollution is complex and dependent upon the type and use of the fuel being subsidized. The World Health Organization estimate that outdoor air pollution was responsible for 3 million premature deaths worldwide in 2012, stating that "Policies and investments supporting cleaner transport, energy-efficient housing, power generation, industry and better municipal waste management would reduce key sources of urban outdoor air pollution" (World Health Organization [WHO], 2016a, np). WHO also recognizes that reducing "outdoor emissions from household coal and biomass energy systems, agricultural waste incineration, forest fires and certain agro-forestry activities (e.g., charcoal production) would reduce key rural and peri-urban air pollution sources in developing regions" (WHO, 2016a, np). Furthermore, WHO notes that emissions from transport fuels such as diesel soot particles and lead are also linked to air pollution with health impacts (WHO, 2016b). Therefore, a switch from government subsidies that support coal - both for the production of electricity and for domestic use such as cooking and 
heating - as well as for transport fuels such as diesel would lead to a switch to other cleaner fuels and potentially a consequent improvement in air quality and health.

Moreover, there is also substantial evidence showing that indoor air pollution from biomass fuels is also a cause of respiratory health problems (Fullerton, Bruce, \& Gordon, 2008). WHO (2016a) recognizes that "[i]n addition to outdoor air pollution, indoor smoke is a serious health risk for some 3 billion people who cook and heat their homes with biomass fuels and coal. Some 4.3 million premature deaths were attributable to household air pollution in 2012." While the argument for removing government subsidies to coal for use in the home and generation of electricity from an air pollution and health perspective is clear, this is not the case for other fossil fuels, such as LPG. Many governments, while reducing and better targeting subsidies to LPG, also understand the improved benefits to households of cooking with cleaner fuels, (such as LPG or biogas, over biomass on open fires) and thus subsidize these fuels and cleaner cook stove as in Peru and Brazil.

Kerosene, on the other hand, is subsidized because it is used by the poor for lighting and, in some countries, for cooking and lighting. Kerosene is sometimes grouped with "clean" fuels (along with LPG, natural gas and electricity) and sometimes with polluting fuels (along with coal and biomass). An extensive literature review of the health impacts of kerosene in cooking, heating and lighting found that when using kerosene for cooking, there was "some evidence that emissions may impair lung function, promote asthma, and increase infectious illness and cataract risks" and that for kerosene lighting there were very few (two) studies with links to tuberculosis risk and acute lower respiratory infections (Lam, Smith, Gauthier, \& Bates, 2012, pp. 424-425). This review highlighted that kerosene "may have some health consequences, not only because of poisonings and fires, but also because of exposure to emitted pollutants. Given the widespread use of kerosene lamps and stoves, these exposure sources should be much more extensively investigated" (Lam et al., 2012, p. 426). Regarding subsidies for kerosene, the study concluded that given "the potential risks of kerosene, policymakers may consider alternatives to kerosene subsidies, such as shifting support to cleaner technologies for lighting and cooking" (Lam et al., 2012, p. 426). In Bangladesh, the one-wick "kupi" kerosene lamp emits heavy smoke with soot causing discoloration of the surrounding walls and ceilings (Khandker et al., 2014).

However, many policy-makers maintain subsidies to kerosene because poor people use it for lighting. The 2015 IMF study bears this out, noting that the benefits of kerosene subsidies are more equally distributed throughout society (Coady et al., 2015). Indeed, in India kerosene prices have been set at INR 15 (USD 0.23) per litre for half a decade, currently representing a 70 per cent discount on market prices (Clarke, 2014). Kerosene subsidies are often the last fossil fuel subsidy to be reformed because of kerosene use in poor households. However, as well as unclear benefits for health, when kerosene is cheaper than diesel due to kerosene subsidies this can also encourage the adulteration of diesel fuels. 
"Fossil fuel subsidies are not producing any global public good, especially in developing countries. But on the contrary, by keeping prices artificially low, they are encouraging inefficiencies and waste for consumption. In fact, they are hampering innovation in technology and improvement on a wider front." - Kare Chawicha, State Minister for Environment and Climate Change, Ethiopia. Speech at IISD Side Event at UN Climate Change Conference COP 22 in Marrakech (15 November 2016).

Figure 4: Environment Gain through the Reform of Energy Subsidies, 2013

(Percent reductions in $\mathrm{CO}_{2}$ emissions on top axis; percent reductions in air pollution deaths on bottom axis)

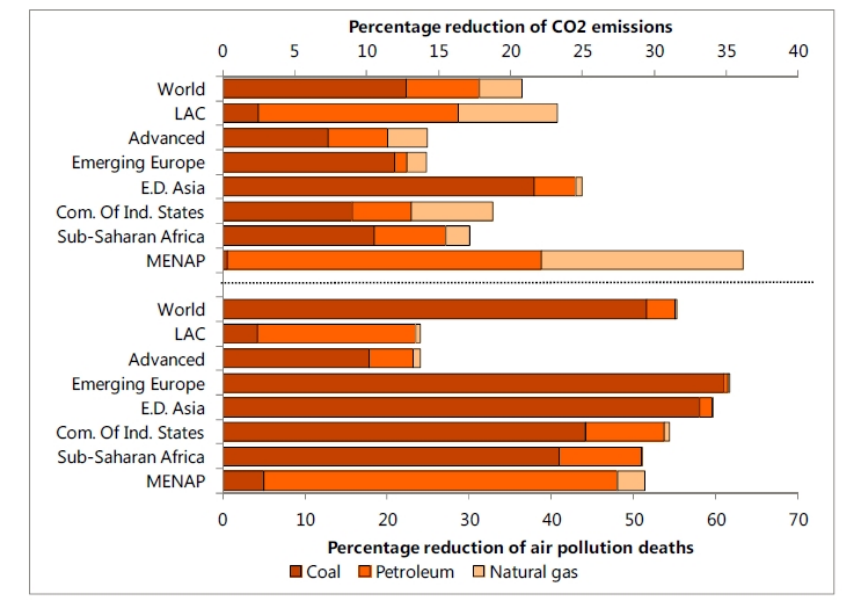

Source: Authors' calculations, based on sources in Appendix Table 2.

Note: $\mathrm{CIS}=$ Commonwealth of Independent States; ED Asia = Emerging and Developing Asia, $\mathrm{LAC}=$ Latin America and the Caribbean; MENAP = Middle East, North Africa, Afghanistan, and Pakistan.

Source: Coady, Parry et al., 2015.

\subsection{Fossil Fuel Subsidies and Gender}

Fossil fuel subsidies, their reform and any potential mitigation measures can impact men, women and children differently. There is very little research on this, but gender impacts and opportunities from reform do need to be considered. The subsidies themselves may be supporting different fuels that confer different benefits and are accessed differently by men and women. For example, women in Nigeria use subsidized kerosene for lighting and cooking purposes and in different ways to men. In 2014, gasoline fuel subsidies in Saudi Arabia stood at almost USD 50 billion (close to 20 per cent of all gasoline subsidies globally) yet women, who are banned from driving, cannot access these subsidies (IEA, 2017; Kitson et al., 2016).

Reforms may offer opportunities for improvements in women's lives. For example in India better targeting of cooking subsidies and a drive to encourage households to use LPG for cooking over kerosene is saving women an average of two hours per week spent cooking (IRADe, 2014). But reforms may also have negative impacts: for example, with the removal of LPG subsidies in India, the increased prices can shift some cooking back to biomass (Sharma, 2014). Finally, social protection mitigation schemes put in 
place to smooth the reforms may benefit and target women and children more directly than the fossil fuel subsidies they replaced (see the section on social protection). These include conditional cash transfers directed to female beneficiaries (and targeting female health or educational attainments) that have been expanded or implemented alongside and following energy sector reforms (as in Peru and Mexico) (Kitson et al., 2016). An initial review of gender and fossil fuel subsidies in India found that they appear to have offered little historical benefit to rural women, affect men and women differently, and that reforms should do no harm to women and rather aim to improve their lives (Merrill, 2014). GSI is currently researching the impact of changes in kerosene and LPG subsidies on poor women in Bangladesh, India, Nigeria, and Indonesia, including with field surveys. An initial extensive literature review covering 28 reforms found that for gender "the impacts of energy subsidies, the impacts of energy sector reform, and workable or appropriate mitigation measures associated with any reforms are extremely context specific. Nonetheless, strong evidence indicates that in many countries a significant proportion of subsidy benefits are captured by well-off households, suggesting a general phenomenon of energy subsidy inefficiency if the desired policy objective is to target income and energy access benefits to women and men living in poverty" (Kitson et al., 2016 and see p. iii). A full outline of the initial findings from this literature review is given in Annex 2. 



\section{Fossil Fuel Subsidies and Climate Change}

The primary motivation for reforming fossil fuel subsidies is to improve government balance sheets and reduce fiscal deficits. There is pressure to reform on importing countries from unsustainable fiscal deficits during times of high oil prices: during periods of low oil prices this pressure is felt by exporting countries. The current low oil price offers governments either the space or urgency to reform. Other key reasons for reform, as described in the preceding chapter, include freeing up resources for other government priorities, better targeting of subsidies toward the poor or toward women, or supporting policies to reduce air pollution.

Therefore, it is clear that associated climate change benefits from reforms are cobenefits. There are many reasons for switching from fossil fuel subsidies and toward better cleaner, fairer energy policies and pricing. Most governments do not approach fossil fuel subsidies (or their reform) from a climate change perspective or for climate change goals. There are significant climate change mitigation benefits from the removal of fossil fuel subsidies and huge opportunities to build resilience and sustainable energy systems with a reinvestment of savings toward sustainable energy. However, when working alongside governments, particularly on consumer subsidy reform, the process should be seen as complementary or a co-benefit of reform efforts, rather than an end in itself. The motivation for governments to reform subsidies is driven by fiscal stability, fairness across society, air pollution and health impacts, energy security and access, as well as opportunities to make fiscal savings and invest in other more productive areas of the economy as outlined earlier.

As an example, in the 1990 s policies and subsidies toward diesel cars in Europe were developed, due to perceived climate change mitigation benefits. However, health impacts from increased particulate matter (diesel is 22 times more polluting to health than petrol) were not considered, yet the subsidies that emerged for the promotion of both diesel cars and diesel fuel over petrol were instrumental in driving large numbers of consumers toward diesel cars (Vidal, 2015). It is important that policy and subsidy changes are modelled and piloted against a wide range of impacts and potential benefits before being enacted across a whole country or region.

Furthermore while fiscal instruments such as fossil fuel subsidy reform (change in government expenditure) and taxation can lead to emissions reductions due to a change in behaviour, these instruments need to be combined with each other and clear regulation. They need to work alongside regulations such as fuel and transport efficiency standards, coal or flaring moratoriums, no-go zones, coal power station phase-out, energy efficiency standards, or other complementary fiscal instruments such as feed-in tariffs for renewables and emissions trading and offset schemes. Fossil 
fuel subsidy reform cannot work alone to bring emissions within the energy sector down and down for the long term. Reform must be combined with clear climate policy and an emissions cap to prevent leakage (see Burniaux \& Chateau, 2014; Schwanitz Piontek, Bertram, \& Luderer, 2014) and with active switching to renewable energy and energy efficiency with savings (Merrill, Bassi et al., 2015).

\subsection{Removal of Consumption Fossil Fuel Subsidies and Reduced Emissions}

In the last few years there has been a growing awareness among governments and an increasing number of studies suggesting a significant link between carbon emissions and the presence or removal of fossil fuel subsidies. An updated overview of this research, first presented in 2015 (Merrill \& Casier) is provided in Annex 3. Research estimates that the removal of all fossil fuel subsidies would lead to a global decrease in carbon emissions of between 6.4-8.2 per cent by 2050 (Schwanitz et al. 2014; Burniaux \& Chateau, 2014). Research funded by the Nordic Council of Ministers enabled the modelling of country subsidy reforms on carbon emissions across 20 individual countries using the GSI-Integrated Fiscal (GSI-IF) model. The research found that across 20 subsidizing countries an average overall drop of 11 per cent in country emissions was achieved through a phase-out of fossil fuel subsidies by 2020. Suggesting average annual savings to governments of close to USD 93 per tonne of greenhouse gas (GHG) emissions removed, or a total (across just 20 countries) of 2.8 gigatonnes (Gt) of $\mathrm{CO}_{2}$ by 2020 (Merrill, Bassi, et al., 2015). This average emissions drop across the countries modelled increased to an average of 18 per cent if a small share of the savings from subsidy reform (a modest 30 per cent) is "switched" or "swapped" into energy efficiency and renewables, with a further 50 per cent allocated for social spending in the model (see Figure 5).

"The only way we are going to do that [establishing a zero emissions economy by 2050] is by unpicking a whole range of subsidies on fossil fuels which, unfortunately, last year alone grew by 30 per cent. The trouble with those subsidies is that they tend to boost emissions rather than encourage a reduction." - A speech by HRH The Prince of Wales at the Unilever Sustainable Living Young Entrepreneurs Awards, Buckingham Palace (3oth January 2014) 
Figure 5: Average emissions reductions from FFSR across 20 countries with $10 \%$ of savings invested in renewables and $\mathbf{2 0} \%$ into energy efficiency (as against business as usual [BAU])

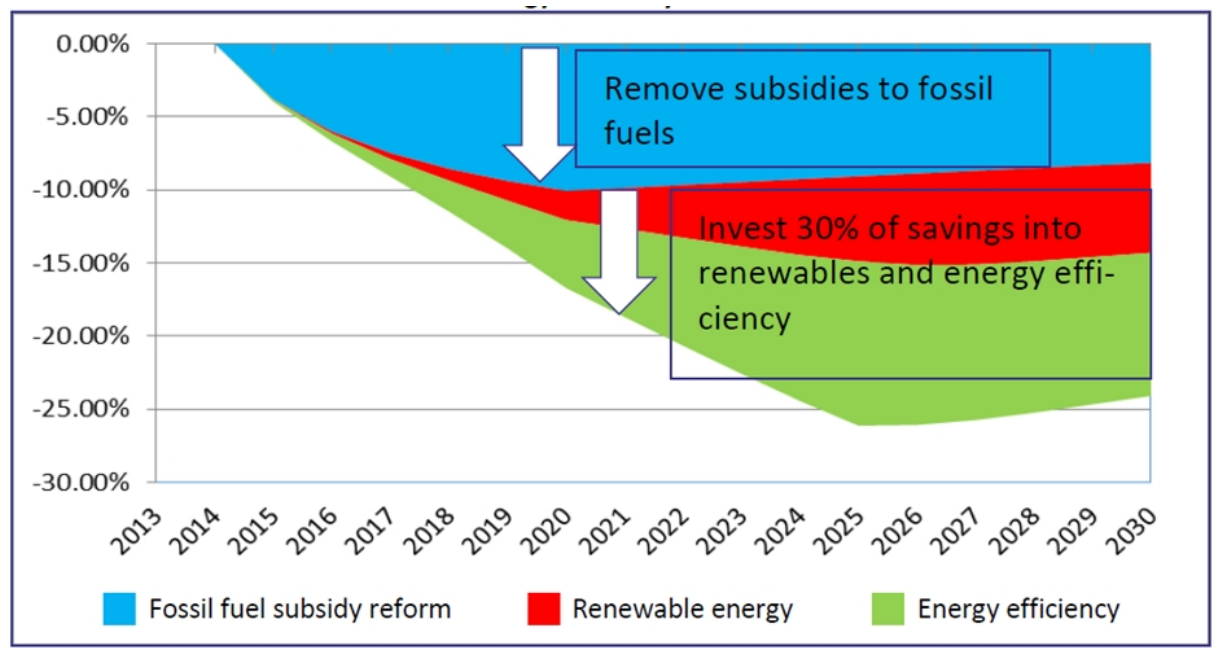

Source: Merrill, Bassi et al., 2015.

Research finds that the range of emissions reductions from the phase-out of consumer fossil fuel subsidies globally is very broad depending on the scenarios utilized, the countries included in the modelling, the scale of the subsidies and the time frame for phase-out. For example, OECD research finds that reform and removal of these subsidies could lead to co-benefits of global emissions reductions of around 3 per cent by 2020 , rising to around 8 per cent by 2050 (Durand-Lasserve, Durand-Lasserve, Campagnolo, Chateau, \& Dellink, 2015; Burniaux \& Chateau, 2014). The IEA (2015a) finds a 10 per cent reduction in energy sector emissions by 2030, from accelerating the partial phase-out of subsidies to fossil fuel consumption. Furthermore, 13 per cent of all energy-related $\mathrm{CO}_{2}$ emissions are linked to average subsidies of USD 115 per tonne of $\mathrm{CO}_{2}$ emitted compared to only 11 per cent of energy emissions that are subject to carbon pricing, with an average cost of just USD 7 per tonne of $\mathrm{CO}_{2}($ IEA, 2015a).

These studies are by no means the first. Research on this issue has been recognized as important among economists for over 20 years: "the removal of fossil fuel subsidies has been advocated as the first order of priority in instituting economic policies to protect local and global environments" (Larsen, 1994, p.2). Reform has more recently been recognized as "a foundation policy for the successful further implementation of many other climate policies: energy efficiency, renewables, innovation, carbon pricing and taxation, public transport infrastructure and the generation of domestic resources for the low-carbon energy transition" (Merrill, Bassi et al., 2015. p. 9). Others also observe that in the long term "all phase-out scenario emissions are returning to the same level as the reference case, since the effects of the phase-out [of fossil fuel subsidies] are less important than other effects that drive emissions like population, GDP growth, or resource depletion" (Schwanitz et al., 2014, p. 886). 
Figure 6: Interlinkages between fiscal instruments and carbon emissions

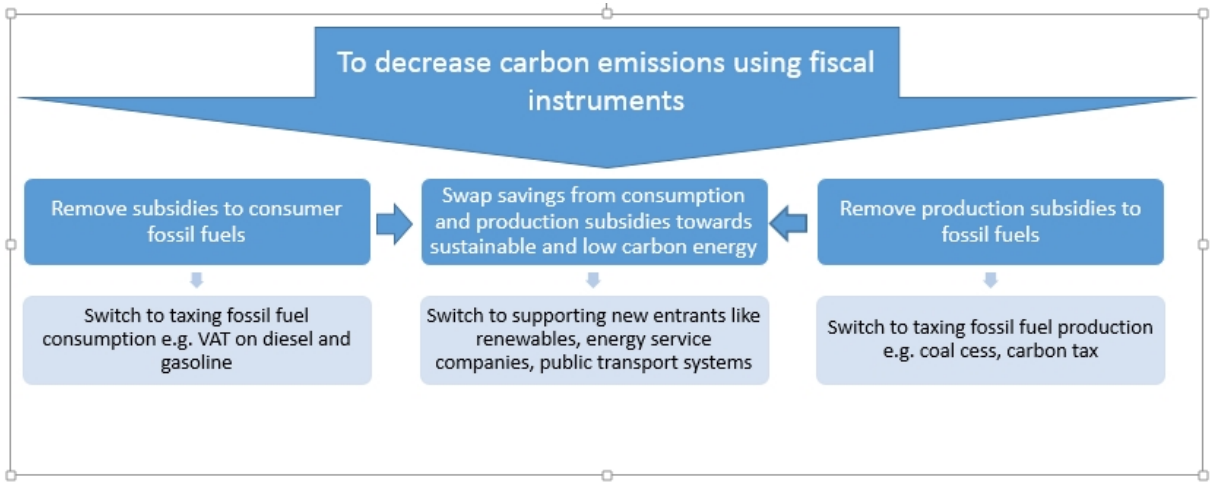

\subsection{SWAP Savings From Fossil Fuel Subsidy Reform Toward Zero Carbon Energy Investments}

However, research on the relationship between the phase-out of consumer fossil fuel subsidies and emissions reductions also stresses that, although the removal of subsidies to consumers does lead to domestic and international reductions in GHG emissions, it is no substitute for a global climate agreement with a clear cap on emissions and clear climate policies (IEA, 2015a; Merrill, Bassi, et al., 2015; Burniaux \& Chateau, 2014; Schwanitz et al., 2014). For example, research has found that fossil fuel subsidy reform in the presence of an emissions cap increases emissions reductions from around 8 to 10 per cent and maintains the reductions from reforms in the long term (Burniaux \& Chateau, 2014). This point is critical. In practice, it means that if countries want to benefit from ongoing and permanent emissions reductions from fossil fuel subsidy reform, they likely need to do two things. First, as the title of this report makes clear, countries need to make the "switch" or the "swap" to cleaner, low-carbon or zero carbon fuels. They need to invest in energy efficiency, renewable energy, public transport schemes and the like in order to help move away from energy systems built on fossil fuels and toward those based on sustainable energy. This swap or switch is described in detail within chapter 5 .

\subsubsection{Tax Fossil Fuels to Lower Emissions}

Second, countries need to tax fossil fuels not only via a carbon tax but via basic Value Added Taxation (VAT) or a Goods and Services Tax (GST). This point is important because there is a wider problem - or rather opportunity - moving forward that is linked to the basic taxation of fossil fuels globally. Namely, not only is there the issue of removing existing subsidies to fossil fuels, but that there is a chronic under-taxation of fossil fuels throughout the global economy (motor gasoline, motor diesel, natural gas and coal). Research by Parry, Heine, Lis \& Li (2014) estimates that the removal of fossil fuel subsidies combined with the correct taxation of fossil fuels could reduce $\mathrm{CO}_{2}$ 
emissions by a much larger 23 per cent globally and potentially raise much-needed revenue to governments of around 2.6 per cent of GDP globally. This is particularly prescient considering the current period of low oil price which encourages overconsumption. Research looking at the combination of both fossil fuel subsidies and the overall level of taxation on fossil fuels also finds that "from 2003 to 2015 , gasoline taxes rose in 83 states but fell in 46 states. During the same period the global mean gasoline tax fell by $13.3 \%$ due to faster consumption growth in countries with lower taxes. Our results suggest that global progress toward fossil fuel price reform has been mixed, and many governments are failing to exploit one of the most cost effective tools for limiting greenhouse gas emissions". (Ross, Hazlett and Mahdavi, 2017).

Furthermore, backward-looking research based on a 170-country, 30-year database found that "Global net subsidies have increased dramatically and steadily since approximately 1998. This seems especially striking, as it is at clear odds with the declared efforts of almost all the world's countries to cut carbon emissions in an effort to combat climate change" (Stefanski, 2016, p. 15).

In Europe there are higher levels of motor fuel taxation, which is not the case elsewhere - i.e., North America and Emerging and Developing Asia, which have far lower levels of fossil fuel taxation. A simple VAT or GST on motor fuels is less complex and politically sensitive to introduce than levies labelled as carbon taxes. They also can be progressive in that owners of private vehicles are likely to be wealthy. Furthermore, increased gasoline or diesel prices (resulting from either a removal of subsidies or from an increase in taxation) would likely lead to increased investment in fuel-efficient vehicles.

"We need to remove fossil fuel subsidies, right now. Or, in other words, we need to establish the right economic incentives to move toward all the way sustainable projects in particular in infrastructure. That implies putting a price on carbon, everywhere." - Felipe Calderon, Former President of Mexico. Speech at Business \& Climate Summit 2016 (London, 28/29 June 2016)

Figure 7 illustrates the gap between current price levels (the white diamond) and appropriate taxation levels (the end of the bar). It also illustrates an implicit price-gap (i.e., a fossil fuel subsidy) where the diamond has a negative value (e.g., for gasoline in Nigeria, Indonesia and Egypt). In other words, many countries could shift their price (diamond) to zero (i.e., remove the fossil fuel subsidies) and many, many more countries could then further shift their price (diamond) to the end of the bar (i.e., representing appropriate fossil fuel taxation). An increase in price (either through subsidy removal or the addition of VAT) leads to a reduction in demand, drives investment in readily available energy efficiency and renewable energy technologies, supports smart regulation and therefore results in decreased GHG emissions. 
Figure 7: Corrective Fuel Taxes to Reflect Environmental Costs, Selected Countries, 2010

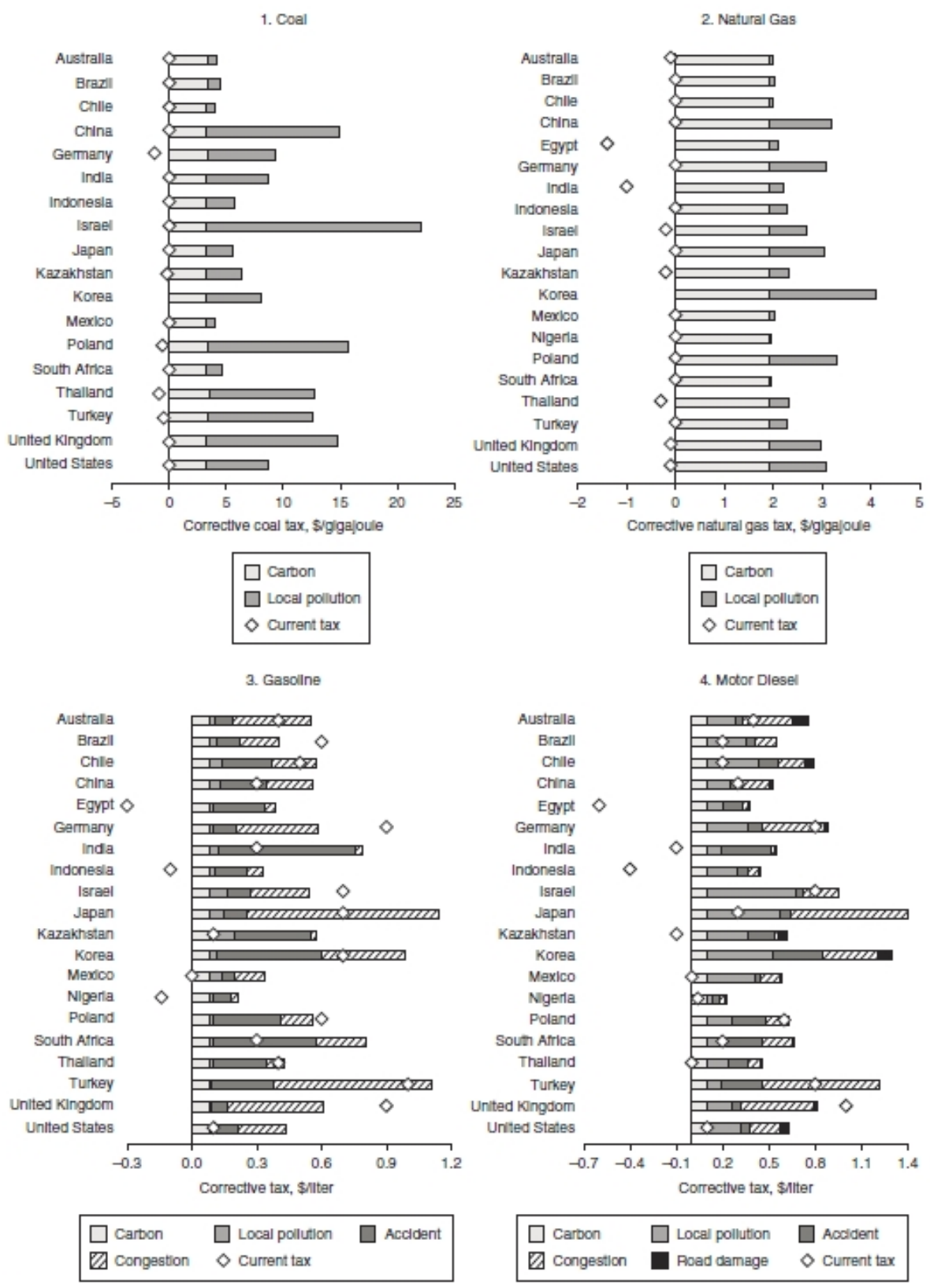

Source: Parry et al. 2014.

While a successful model of taxation exists for motor fuels (gasoline and diesel), this is not the case for coal (see Figure 7). Coal not only has huge carbon and climate implications, but also immediate health and pollution impacts that are often ignored within its pricing. For example, McGlade \& Ekins $(2015$, p. 187) find that "globally, a third of oil reserves, half of gas reserves and over 80 per cent of current coal reserves should remain unused from 2010 to 2050 in order to meet the target of $2^{\circ} \mathrm{C}$." The IMF global estimate of fossil fuel subsidies, which includes the significant cost of both carbon 
emissions and pollution impacts on society's health (i.e., post-tax consumer subsidies, see Annex 1), places the cost at around 4.9 trillion annually in 2013, rising to USD 5.3 trillion in 2015 (Coady, et al., 2015). Currently, the external costs of fossil fuels are not fully accounted for within their price. Nominal global subsidies for coal are estimated by the IEA to be USD 1 billion in 2015 (compared to oil subsidies of USD 145 billion) (IEA, 2016c). However, such a nominal figure does not consider coal's externalities. Others find that "among different energy products, coal accounts for the biggest subsidies, given its high environmental damage and because (unlike for road fuels) no country imposes meaningful excises on its consumption" (Coady et al., 2015b, p. 6).

With the current combination of fossil fuel subsidies and chronic under-taxation, the opposite of correct energy pricing occurs. In 2014, 13 per cent of energy-related carbon dioxide emissions were from subsidized fossil fuels (equivalent to a government subsidy of USD 115 per tonne of $\mathrm{CO}_{2}$ ) - compared to 11 per cent of energy-related carbon emissions covered by emissions trading schemes and priced at around USD 7 per tonne (IEA, 2015a).

\subsection{Removal of Upstream Producer Subsidies and Further Emissions Reductions}

The above discussion focuses on the removal of consumer subsidies to fossil fuels, often because data for information on production subsidies is so opaque. There are a range of estimates of the emission savings from a removal of subsidies to fossil fuel production. Results are sensitive to the data inputs, as estimates of fossil fuel production subsidies remain incomplete (Bast et al., 2015; Gerasimchuk et al., 2017). The order of magnitude of emission savings also depends on the geographical scope, fuels under examination, time horizon of the analysis, assumptions about fossil fuel prices as well as on whether or not second-order impacts are included. Meanwhile, existing research indicates that a removal of certain fossil fuel production subsidies can have significant impacts.

For example, Sawyer \& Stiebert (2010) estimated that the removal of subsidies to upstream oil and gas in Canada would reduce oil production in three Canadian provinces by 5 per cent between 2011 and 2020, and would decrease Canada's emissions by 2 per cent (10 per cent in oil sands). Acar \& Yeldan (2016) estimated that eliminating coal production subsidies in Turkey would lead to a 2.5 per cent decline in total emissions by 2030. Additionally, removal of regional investment subsidies would reduce emission by 5.4 per cent. Both studies use general equilibrium models, with the impacts on the economy estimated to be insignificant.

Erickson et al. (2017) show that billions of dollars in federal and state subsidies enable large amounts of oil and gas production in the U.S. that would not otherwise be economic. At USD 50 per barrel (roughly the January 2017 oil price) 45 per cent of discovered (but not yet producing) U.S. oil would depend on subsidies to reach investors' minimum acceptable returns. The additional oil produced due to subsidies would emit 8 billion tonnes of $\mathrm{CO}_{2}$. 
Gerasimchuk et al. (2017) provide the first measurement of both first- and secondorder impacts of a global removal of subsidies to fossil fuel production. Their paper finds that a complete removal of subsidies to fossil fuel production globally would reduce the world's emissions by $37 \mathrm{Gt}$ of $\mathrm{CO}_{2}$ over 2017 - 2050. This is roughly the amount of carbon dioxide that would result from burning all proven oil reserves in the United States and Norway, or estimated global emissions from the aviation sector over the same period. The research describes how fossil fuel subsidies upstream to producers create "zombie energy," i.e., production from fields that would be economically unviable without government support; how they skew energy markets and act as a negative carbon tax, artificially lowering the cost of producing more oil, coal and gas, that can be passed through in the form of lower market prices, encouraging more fossil fuel consumption and emissions; and that government support to fossil fuel production locks in fossil fuel dependency by giving strong signals to investment decision makers.

Stefanski (2016) offers the only study that looks retrospectively at the climate benefits of removing both production and consumption subsidies. This research is based on data from the last 30 years of industrial development pathways across 170 countries and finds that the financial and environmental costs of such subsidies are enormous. For 2010 alone, the research finds that "the total global direct and indirect financial costs of all such subsidies amounted to $\$ 1.82$ trillion, or $3.8 \%$ of global GDP. Aside from the money saved, in 2010 a world without subsidies would have had carbon emissions $36 \%$ lower than they actually were" (Stefanski, 2016).

"Fossil fuel subsidy reform is the missing piece of the climate change puzzle. It's estimated that more than a third of global carbon emissions, between 1980 and 2010, were driven by fossil fuel subsidies. Their elimination would represent one seventh of the effort needed to achieve our target of ensuring global temperatures do not rise by more than $2^{\circ} \mathrm{C}$. As with any subsidy reform, change will take courage and strong political will, but with oil prices at record lows and the global focus on a low-carbon future, the timing for this reform has never been better." - John Key, Prime Minister of New Zealand. (Presenting the Communiqué to the UNFCCC, 30th November 2015) 


\section{Support for Fossil Fuel Subsidy Reform}

\subsection{National Fossil Fuel Subsidy Reform}

There are numerous reasons for governments to reform current subsidies to fossil fuels. Many governments are recognizing this, and some have reformed their subsidies or are in the process of phasing them out. In 2015 and 2016, with low oil prices, around 50 countries increased or removed government controls on prices of fossil fuels, directly or partially removing subsidies.

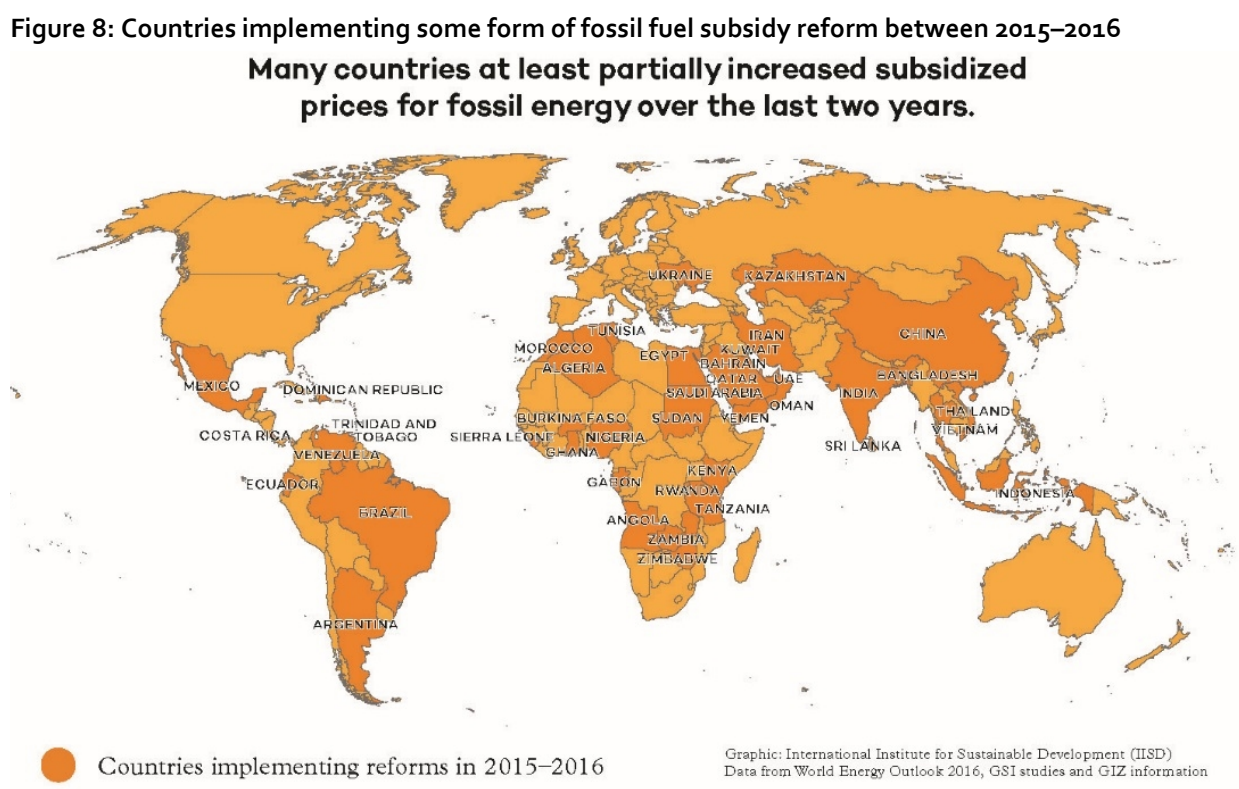

\subsection{Nordic Support}

The Nordic countries actively use fiscal measures to influence energy and climate policies. In 2013 Finland scrutinized 400 subsidy measures according to their environmental and social impacts and costs. The subsidies were categorized with an intuitive traffic-light system, which helped directing corrective measures toward those which are the most harmful (Finnish Ministry of Finance, 2016).

During 2006-2010, Sweden offered a 30 per cent material and construction cost subsidy to households to accelerate switching from conventional heating to heat pumps, which are now installed in go per cent of new houses (Energimyndigheten, 
2015). In Norway, electric vehicles are exempted from VAT, which (among other incentives) has made Norway a global leader in electric car use - electric vehicles now have a 23 per cent market share of all new cars sold in Norway (IEA, 2016b).

Denmark is a prime example of how a long-lasting and predictable support scheme yields benefits to not only the environment, but also national economy. The country has operated a feed-in tariff system for wind power ever since the 1990 (International Renewable Energy Agency [IRENA], 2013); lifting the share of wind power from 3 per cent to 42 per cent in electricity production (IEA, 2016a). Wind power in Denmark is now a EUR 10 billion annual industry employing 30,000 people (Danish Wind Industry Association, 2016).

\subsection{International Support}

\subsubsection{Friends of Fossil Fuel Subsidy Reform and the Fossil Fuel Subsidy Reform Communiqué}

Denmark, Finland, Norway and Sweden are members of the Friends of Fossil Fuel Subsidy Reform, along with Costa Rica, Ethiopia, New Zealand, Switzerland and Uruguay. The Friends were established in June 2010 to support G20 and Asia-Pacific Economic Cooperation (APEC) leaders' commitments to phasing out inefficient fossil fuel subsidies. In April 2015, the Friends launched the Fossil Fuel Subsidy Reform Communique at the annual World Bank Springs meeting along with the support of the United States and France. The Communiqué encourages the international community to advance fossil fuel subsidy reform through three principles:

- Increased transparency around fossil fuel subsidies.

- Ambitious reform.

- Targeted support to ensure reforms are implemented in a manner that safeguards the poorest.

The Communiqué was presented to countries for endorsement at various international events throughout 2015, including: the Bonn meetings in the lead-up to Paris; Financing for Development in Ethiopia; as part of the SDGs; and the Clean Energy Summit, and it built momentum throughout the year. The Communiqué was handed over by world leaders to the then-UNFCCC Executive Secretary Christiana Figueres at COP 21 in Paris, in November 2015, to support efforts to reach a new global climate agreement.

"Fossil fuel subsidy reform has both economic and climate benefits. Reform will free up financing for sustainable development. Norway will contribute 100 million Norwegian kroner (app. USD 12.5 million) to fossil fuel subsidy reform, and we strongly encourage other countries to increase their efforts and support the call for reform," said Børge Brende, Norwegian Minister of Foreign Affairs at the April 2015 launch. 


\subsubsection{Existing Programs of Support and Information on FFSR}

Current programs to support countries through the process of energy sector reform include the World Bank's Energy Sector Management Assistance Program Map (ESMAP) via the Energy Subsidy Reform and Technical Assistance Delivery Facility and publications. The International Energy Agency (IEA) is involved through the provision of information via the World Energy Outlook and support to countries such as Mexico and Indonesia. The International Monetary Fund (IMF) provides research and loan support linked to fiscal reforms. The OECD assists through its inventory of support measures for fossil fuels (for OECD and partner countries: Brazil, China, India, Indonesia, Russia and South Africa) and the accompanying companion publication (OECD, 2015). The Global Subsidies Initiative (GSI) of the International Institute for Sustainable Development also supports between eight to ten countries directly with programs of work and broadly through the provision of data, information and publications via its website (www.globalsubsidies.org)

\subsubsection{Support at the International Level on FFSR}

Table 2 outlines the different venues where the issue of fossil fuel subsidy reform has gained support.

Table 2: Supportive Language on FSSR

\begin{tabular}{|c|c|c|}
\hline Venue & Language & Progress \\
\hline G20 & $\begin{array}{l}\text { "We also reaffirm our commitment to rationalize and phase-out } \\
\text { inefficient fossil fuel subsidies that encourage wasteful consumption } \\
\text { over the medium term, recognizing the need to support the poor. } \\
\text { We welcome } \mathrm{G}_{20} \text { countries' progress on their commitments and } \\
\text { look forward to further progress in the future. Further, we } \\
\text { encourage G20 countries to consider participating in the voluntary } \\
\text { peer review process" (G20, 2016). }\end{array}$ & $\begin{array}{l}\text { G2o first introduced a similar statement } \\
\text { in } 2009 . \\
\text { Peer reviews available for the United } \\
\text { States and China, and expected from } \\
\text { Germany, Mexico and Indonesia. }\end{array}$ \\
\hline APEC & $\begin{array}{l}\text { "We reaffirm our aspirational goals to reduce aggregate energy } \\
\text { intensity by } 45 \text { per cent by } 2035 \text { and double renewable energy in the } \\
\text { regional energy mix by } 2030 \text {. We reaffirm our commitment to } \\
\text { rationalize and phase out inefficient fossil fuel subsidies, welcome } \\
\text { ongoing peer review and capacity building activities, and encourage } \\
\text { further efforts to facilitate subsidy reform" (APEC, 2016). }\end{array}$ & $\begin{array}{l}\text { G20 first introduced a similar statement } \\
\text { in } 2009 . \\
\text { Peer reviews available for Peru, } \\
\text { Philippines, and New Zealand, and } \\
\text { expected from Vietnam, Chinese Taipei } \\
\text { and Brunei. }\end{array}$ \\
\hline $\mathrm{G}_{7}$ & $\begin{array}{l}\text { In } 2016, \mathrm{G}-7 \text { countries "committed to phasing out inefficient fossil } \\
\text { fuel subsidies that encourage wasteful consumption, and encourage } \\
\text { all countries to do so by } 2025^{\prime \prime}(\mathrm{G} 7,2016) \text {. }\end{array}$ & \\
\hline SDGs & $\begin{array}{l}\text { In } 2015 \text { the issue was included within the Sustainable Development } \\
\text { Goals as part of Goal } 12 \text { on sustainable consumption and production } \\
\text { patterns as a Means of Implementation, again to "rationalize } \\
\text { inefficient fossil fuel subsidies that encourage wasteful } \\
\text { consumption" UNSTATS (2016). }\end{array}$ & $\begin{array}{l}\text { All countries to voluntarily report against } \\
\text { the following indicator: amount of fossil } \\
\text { fuel subsidies per unit of GDP } \\
\text { (production and consumption) and as a } \\
\text { proportion of total national expenditure } \\
\text { on fossil fuels. }\end{array}$ \\
\hline
\end{tabular}

Financing for In 2015, the issue was included within the Addis Ababa Action Development Agenda, namely "to rationalize inefficient fossil fuel subsidies that (FfD) encourage wasteful consumption" (UN, 2015). 
European

Parliament

Paragraph 13: "Calls on the Member States to ban fossil fuel subsidies that lower the cost of fossil fuel energy production, with a view to discouraging the exploitation and use of fossil fuels" (European Parliament, 2017).

UNFCCC

The Paris Agreement is silent on the issue of fossil fuel subsidies directly but includes language on "Making finance flows consistent with a pathway toward low greenhouse gas emissions and climate resilient development." (Article 2 ) and "...recognizes the important role of providing incentives for emission reduction activities, including tools such as domestic polices and carbon pricing, and ,Regular Technical Experts meetings focusing on specific policies, practices and actions" (Pre-2020 action).

Friends of

Fossil Fue

Subsidy

Reform

At COP 21 in Paris, John Key, the Prime Minister of New Zealand, presented an international Communiqué endorsed by countries, including Canada, Chile, France, Germany, Italy, Malaysia, Mexico, New Zealand, Peru, the Philippines, the United Kingdom and the United States, (from the G20 and APEC). The success of the Communiqué has been driven by the Friends of Fossil Fuel Subsidy Reform, an informal group of nine non-G2o countries working to build political consensus on the importance of fossil fuel subsidy reform (www.fffsr.org).

Civil society organizations (CSOs)

In 2016 a statement delivered to $\mathrm{G}_{20}$ Finance Ministers ahead of the Energy Ministerial Meeting more than 200 civil society organizations (CSOs) urged G2o governments to take action on fossil fuel subsidy reform (Oil Change International [OCI], 2016).

Insurers

Released a statement in 2017 calling for the $\mathrm{G}_{20}$ "To catalyse real progress on phasing out fossil fuel subsidies, the German $\mathrm{G}_{20}$ communiqué should include clear language that:

Sets a clear timeline for the full and equitable phase-out by all $\mathrm{G}_{20}$ members of all fossil fuel subsidies by 2020 , starting with the elimination of all subsidies for fossil fuel exploration and coal production.

Sets a clear timeline for the phase-out of domestic and internationa public finance for oil, gas and coal production by 2020 .

Commits all $\mathrm{G}_{2}$ o members to complete fossil fuel subsidy peer reviews by the end of 2018, building on the leadership of China and the United States in 2016" (Overseas Development Institute [ODI], 2017).

Climate

Vulnerable

Forum

"Noting the $V_{2}$ o commitment to working to establish pricing regimes, we will consider and share experiences on ways of effectively and fairly using such instruments.

We strive to eliminate high-carbon investments and harmful subsidies, including through enhancing enabling environments both at the international and national levels so as to decarbonise the global economy rapidly" (CVF, 2016).
As part of an integrated EU policy for the Arctic.

14 countries included the issue in their NDC. A TEM covered the issue in 2016.

Over 40 countries and business associations representing over 90,000 businesses.

200 civil society groups calling for action.

Insurers investing more than USD 3.5 trillion in assets called on the $\mathrm{G}_{2} \mathrm{O}$ to phase fossil fuel subsidies out by 2020 .

40 countries under the CVF linked to the Vulnerable 20 group called for the elimination of harmful subsidies. 


\section{Making the Switch}

\subsection{What is a Fossil Fuel SWAP?}

Energy and fuel switching is not a new concept. Consumers switch between energy companies. Those cooking in the household switch between gas and electricity or between charcoal and kerosene for cooking. Motorists switch from gasoline to electric cars, or from gasoline to diesel cars and fuels. Even investors switch. The divestment campaign where private and institutional investors shift investment assets away from fossil fuel companies is a marketplace example. What this paper outlines is a similar switch in government expenditure and policy. But it is actually more than a switch - or tinkering with a stacking model, whereby households use a mix of fuels to deliver energy needs - what is needed is a SWAP. In other words, a direct act of exchanging one type of energy source subsidies for another. A SWAP requires not only switching off the carbon subsidies that flow to fossil fuels but a parallel switching on of active support and investment into renewable and energy efficiency services. A SWAP is where countries implement fossil fuel subsidy reform and allocate some savings from reform toward sustainable energy and development.

Figure 9: Developing FFS Swaps
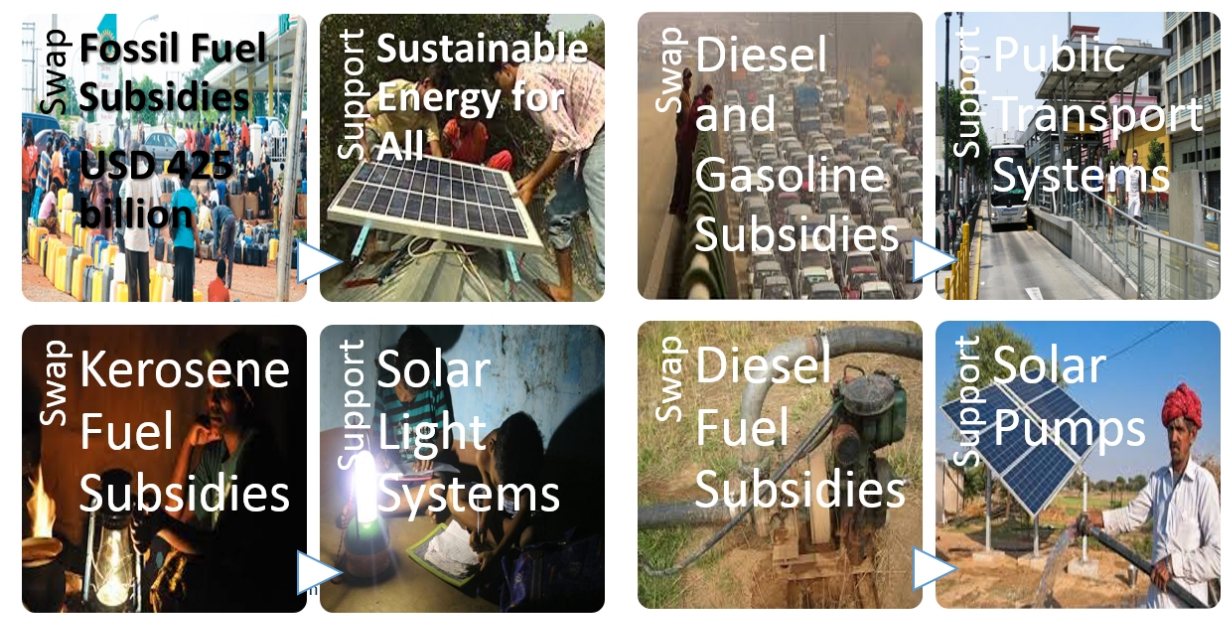

But this needs to be a massive switch, a massive swap, on a scale and level similar to that we have seen from fixed line to mobile communications technologies. A rapid redeployment of the current USD 425 billion of government downstream and upstream government subsidies spent on fossil fuels, redirected away from these fuels and into sustainable energy. It is a huge and desperately needed idea in an age of scarce resources and a planet undergoing climate change. The Intergovernmental Panel on 
Climate Change (IPCC) (2014) reports that to stay within a $2{ }^{\circ} \mathrm{C}$ warming target, global emissions need to remain below a total of 2,900 Gt CO2e. Of that total, 1,900 have already been emitted by 2011: as of 2010 there were around $49 \mathrm{Gt}$ emitted per year (IPCC, 2014). According to McGlade \& Ekins (2015, p.187), [i]t has been estimated that to have at least a 50 per cent chance of keeping warming below $2^{\circ} \mathrm{C}$ throughout the twenty-first century, the cumulative carbon emissions between 2011 and 2050 need to be limited to around 1,100 gigatonnes of carbon dioxide. [Yet] ... the greenhouse gas emissions contained in present estimates of global fossil fuel reserves are around three times higher than this, and so the unabated use of all current fossil fuel reserves is incompatible with a warning limit of $2^{\circ} \mathrm{C}$.

Others also find that "potential carbon emissions from the oil, gas, and coal in the world's currently operating fields and mines would take us beyond $2^{\circ} \mathrm{C}$ of warming. The reserves in currently operating oil and gas fields alone, even with no coal, would take the world beyond $1.5^{\circ} \mathrm{C}^{\prime \prime}$ (Muttitt, 2016). Remaining within a $2{ }^{\circ} \mathrm{C}$ threshold will require a rapid, but managed, decline in the fossil fuel industry. This must begin with cutting off government subsidies to fossil fuels. Removal of subsidies to fossil fuels enables the removal of gigatonnes of $\mathrm{CO}_{2} \mathrm{e}$ in the near term i.e., pre-2020.

"To be clear, this is not about just telling people to change their light bulbs or to buy a hybrid car. This disaster has grown BEYOND the choices that individuals make. This is now about our industries, and governments around the world taking decisive, large-scale action. (. . .) Now is our moment for action. We need to put a price tag on carbon emissions, and eliminate government subsidies for coal, gas, and oil companies. We need to end the free ride that industrial polluters have been given in the name of a free-market economy, they don't deserve our tax dollars, they deserve our scrutiny. For the economy itself will die if our ecosystems collapse." - Leonardo di Caprio, actor and climate change activist (New York, UN Climate Summit 23 September 2014.

A SWAP of the scale and speed needed could open up extraordinary opportunities to first movers, not only in terms of technological innovation and learning, but also in terms of fairness, energy access and empowerment, reduction in corruption and energy security. Big ideas and actions are made up of smaller actions. Many countries such as Morocco, Peru, The Philippines and Ethiopia have started to make this shift (Merrill et al., 2016). Many others could make the SWAP, and four potential SWAP projects are outlined in this report for Bangladesh, Indonesia, Morocco and Zambia - countries all with significant subsidies currently undergoing reform. Further opportunities for China and the United States are based on recent GSI research. All countries could review their subsidies to fossil fuels and identify where they could re-invest some or all of the savings toward sustainable development and sustainable energy in particular. 
Table 3: Potential SWAPs between fossil fuel subsidies and sustainable energy

\begin{tabular}{|c|c|c|c|}
\hline Country & Away from & Swap Toward & Emissions and Financial Savings \\
\hline $\begin{array}{l}\text { Bangladesh } \\
\text { (chapter 6) }\end{array}$ & $\begin{array}{l}\text { Diesel subsidies } \\
\text { and diesel } \\
\text { pumps } \\
\text { Gas subsidies } \\
\text { Fuel subsidies }\end{array}$ & $\begin{array}{l}\text { Solar pumps } \\
\text { Energy } \\
\text { efficiency in the } \\
\text { garment sector } \\
\text { Safety nets }\end{array}$ & $\begin{array}{l}\text { Total diesel sales to the agriculture sector in } 2015-16 \text { amounted to } \\
\text { (approximately) USD } 761 \text { million. Removal of all fossil fuel subsidies } \\
\text { ( } 4.6 \% \text { of GDP in 2013) found an } 8.6 \% \text { emissions reduction, reaching a } \\
13.5 \% \text { reduction with a swap (GSI-IF). }\end{array}$ \\
\hline $\begin{array}{l}\text { Indonesia } \\
\text { (chapter 7) }\end{array}$ & $\begin{array}{l}\text { LPG subsidies } \\
\text { Coal production } \\
\text { subsidies }\end{array}$ & $\begin{array}{l}\text { Social safety } \\
\text { nets } \\
\text { Renewable } \\
\text { electricity } \\
\text { generation }\end{array}$ & $\begin{array}{l}\text { Total coal subsidies to electricity over USD } 600 \text { million in in } 2015 \text {, } \\
\text { compared to USD } 130 \text { million to renewables. Removal of all fossil fuel } \\
\text { subsidies ( } 7 \cdot 3 \% \text { of GDP in 2012) gave a } 7 \% \text { emissions reduction, reaching } \\
\text { a } 12 \% \text { reduction with a swap (GSI-IF). }\end{array}$ \\
\hline $\begin{array}{l}\text { Morocco } \\
\text { (chapter 8) }\end{array}$ & $\begin{array}{l}\text { Butane subsidies } \\
\text { and agriculture } \\
\text { pumps }\end{array}$ & Solar pumps & $\begin{array}{l}\text { Current subsidies stand at USD } 1.13 \text { billion in } 2016 \text {, down from a high of } \\
\text { USD } 5.79 \text { billion in } 2012 \text {. The subsidy reforms already completed would } \\
\text { bring about GHG emission reductions of } 6.6 \% \text { annually on average } \\
\text { between } 2012 \text { and } 2030 \text {. The hypothetical phase-out of both butane and } \\
\text { electricity subsidies by } 2020 \text { would result in an additional o.9\% in } \\
\text { average annual reductions (approximately } 2.8 \mathrm{Mt} \mathrm{CO}_{2} \mathrm{e} \text { ), for a total of } \\
\text { annual average reductions of 7.5\% between } 2012 \text { and } 2030 \text {. (GSI-IF) } \\
\text { (Gagnon-Lebrun \& Bassi, 2015). }\end{array}$ \\
\hline $\begin{array}{l}\text { Zambia } \\
\text { (chapter 9) }\end{array}$ & $\begin{array}{l}\text { Diesel and heavy } \\
\text { fuel oil subsidies } \\
\text { Diesel and } \\
\text { electricity } \\
\text { subsidies to } \\
\text { mining }\end{array}$ & $\begin{array}{l}\text { Cash transfers } \\
\text { Low-cost } \\
\text { renewable } \\
\text { energy } \\
\text { Mining sector } \\
\text { efficiency }\end{array}$ & $\begin{array}{l}\text { Total subsidy bill for } 2015 \text { estimated at USD } 2 \text { billion (IMF). The total } \\
\text { saving from converting all oil-based generation to solar would save a } \\
\text { total of USD } 34.8 \text { million. Based on emissions from oil-based generation } \\
\text { for Zambia (Zhou et al., 2009), this would lead to a reduction in } \mathrm{CO}_{2} \\
\text { emissions of nearly 400,000 tonnes of } \mathrm{CO}_{2} \text {. }\end{array}$ \\
\hline India & $\begin{array}{l}\text { Kerosene } \\
\text { subsidies and } \\
\text { lighting }\end{array}$ & $\begin{array}{l}\text { Solar lighting } \\
\text { systems }\end{array}$ & $\begin{array}{l}\text { Removal of all fossil fuel subsidies ( } 3.4 \% \text { in } 2012 \text { ) found emissions } \\
\text { reductions of } 3.2 \% \text { by } 2020 \text { or } 0.3 \mathrm{Gt} \text {, improving to a } 5.94 \% \text { reduction } \\
\text { with a SWAP (GSI-IF). }\end{array}$ \\
\hline United States & Coal subsidies & $\begin{array}{l}\text { Energy } \\
\text { efficiency and } \\
\text { just transition }\end{array}$ & $\begin{array}{l}\text { US peer review (2016) identified USD } 8.2 \text { billion worth of subsidies. } \\
\text { Research identified USD } 20 \text { billion of fossil fuel production subsidies } \\
\text { (Bast et al., 2015). Removal of fossil fuel subsidies (o.6\% of GDP in } 2012 \\
\text { based on IEA data only) found emissions reductions of o.18\% by } 2020 \text { or } \\
0.04 \text { Gt, improving to } 0.38 \% \text { reduction with a SWAP (GSI-IF). }\end{array}$ \\
\hline China & Coal subsidies & $\begin{array}{l}\text { Energy } \\
\text { efficiency and } \\
\text { just transition }\end{array}$ & $\begin{array}{l}\text { China peer review (2016) identified USD } 14.5 \text { billion in subsidies. Further } \\
\text { subsidies to coal generators, including for cleaner and more efficient } \\
\text { burning of coal, were estimated to be: USD } 37.7 \text { billion in } 2014 \text { and USD } \\
18 \text { billion in } 2015 \text { (Denjean, Attwood, Bridle, \& Gerasimchuk, 2016) and } \\
\text { subsidies to coal mining estimated to be USD } 5.8 \text { billion in } 2013 \text { (Xue et } \\
\text { al., 2015). Removal of all fossil fuel consumption subsidies (0.6\% of GDP } \\
\text { in } 2012 \text { based on IEA data only) found emissions reductions of } 0.78 \% \text { by } \\
2020 \text { or } 0.25 \text { GT, reaching 1.29\% reduction with swap (GSI-IF). }\end{array}$ \\
\hline
\end{tabular}

Note: GSI-IF figures, apart from Morocco, are all based on and detailed in Merrill, Bassi et al. (2015). The SWAPs modelled in GSI-IF are based on subsidy data from IEA and IMF and assume a 30 per cent reinvestment of savings from the phase-out into renewable energy (10 per cent) and energy efficiency (20 per cent). National percentage reductions are a drop in national emissions as against a BAU baseline. For more details on the SWAPs proposed in Bangladesh, Indonesia, Morocco, and Zambia see the latter part of this document.

Source: Authors. 


\subsection{How Does a SWAP Work?}

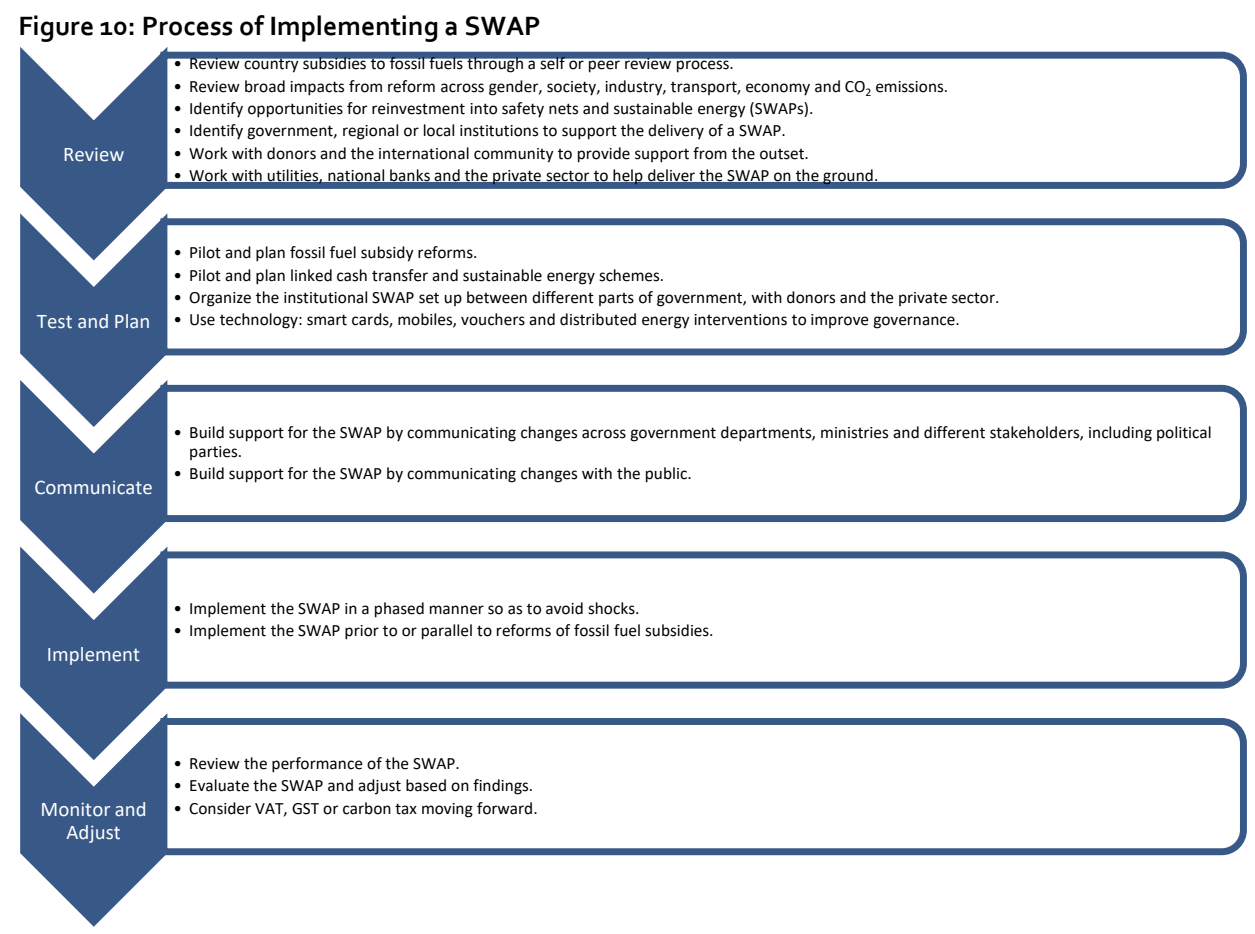

\subsection{International Experience of Sustainable Energy Programs}

Sustainable energy programs that achieve transformational changes typically shape the enabling environment for investments and address issues far beyond the energy sector. Indeed, in many cases transformational energy programs simultaneously address questions of financial disparity and social benefits as well as the environment.

Successfully implementing fossil fuel subsidy reform requires - beyond in-depth knowledge of the energy sector - wide understanding of the social economics and political structures of the target country. While few "traditional" energy sector programs, initiatives and/or projects comprehensively addresses the enabling environments, and simultaneously promoted sustainable energy business and livelihoods development, there is an increasing understanding of the need to address project-level, sector-level as well as national /enabling environment-level challenges coherently. Valuable lessons can be learned from existing energy and climate initiatives, in order to plan and implement fossil fuel subsidy reform effectively and sustainably. Wider energy sector programs (such as the GET FiT, see below) provide useful insights on the importance of the enabling environment and how to remove investment barriers and engage the private sector in climate action. Numerous experiences from existing climate funds (such as the Nordic Development Fund, see below) provide useful insights on the importance of understanding the socioeconomic 
context for ensuring affordability and access, and hence effectively and concretely contribute to the ultimate goal of reducing poverty.

The Global Energy Transfer Feed-in Tariffs (GET FiT) program aims to incentivize private investment in renewable energy in East Africa by building the enabling environment. It demonstrates and promotes the attractiveness of the investments by 1) topping existing feed-in tariffs, 2) building local capacity (e.g., standardization of PPAs, tariff modelling, interconnections) and 3) providing access to guarantees. These actions are aimed toward the identified key investment barriers according to Table 4 .

Table 4: Effects of GET FiT program against key investor risks (derived from GETFiT Uganda, 2016)

\begin{tabular}{|c|c|c|}
\hline Barrier & Action & Effect \\
\hline $\begin{array}{l}\text { Energy tariffs too low to incentivize } \\
\text { investments }\end{array}$ & Premium feed-in tariff & $\begin{array}{l}\text { The tariff is relied upon by investors, } \\
\text { as it is backed up by donor funding } \\
\text { and is high enough to ensure profit. }\end{array}$ \\
\hline High transaction costs & $\begin{array}{l}\text { Standardized PPAs and other legal } \\
\text { documents }\end{array}$ & $\begin{array}{l}\text { Standard documents provide a robust } \\
\text { contractual basis and reduce } \\
\text { transaction and legal costs. }\end{array}$ \\
\hline High regulatory risk & Capacity building & $\begin{array}{l}\text { Electricity Regulatory Agency gains } \\
\text { more awareness of impacts of } \\
\text { regulatory changes. }\end{array}$ \\
\hline High offtaker risk & Partial Risk Guarantees (PRGs) & $\begin{array}{l}\text { Investors are being compensated in } \\
\text { the case of nonpayment by the } \\
\text { offtaker. }\end{array}$ \\
\hline High Power risk & Interconnector component & $\begin{array}{l}\text { Likelihood of deemed energy is } \\
\text { reduced by improving the } \\
\text { performance of the grid. }\end{array}$ \\
\hline
\end{tabular}

The GET FiT program started in Uganda, where it was developed by the Government of Uganda, the Ugandan Electricity Regulatory Agency and Kreditanstalt für Wiederaufbau (KfW) a German government-owned development bank, with a total donor commitment of EUR 94 million (GET FiT-Uganda, 2016). The program is expected to stabilize and diversify the power sector and increase installed capacity by 20 per cent, thereby improving energy access for at least 200,000 households (U.K. Government, 2016). Estimated environmental benefits yield up to 11 million tonnes of saved $\mathrm{CO}_{2}$ during the 20-year lifespan of the plants (GET FiT, 2017). The program has already delivered $30 \mathrm{MWs}$ of commissioned capacity, with $86 \mathrm{MW}$ in construction, which created 1,500 jobs in 2016. The scale of the impact is amplified, because through USD 104 million in Premiums GET FiT has leveraged an estimated USD 428 million of investments (GET FiT, 2017).

The lessons learned from reform-supporting programs such as GET FiT are closely followed by The Private Sector Facility (PSF) of the Green Climate Fund (GCF), as it aims to redirect "a material portion of USD 115 trillion of financial assets held by commercial banks toward green projects" by technology diffusion, involving local actors and aggregating groups of projects into single investment vehicles. PSF distributes funds through accredited agencies according to its mandate of engaging private sector actors in climate-related projects in the developing world (GCF, 2017). 
Since late 2008, the Climate Technology Initiative Private Financing Advisory Network (CTI PFAN) has raised over USD 1.2 billion for 87 projects (with a total of 358 projects in the pipeline), concentrating on sustainable energy, energy efficiency and electrification. CTI PFAN sees that renewable energy projects are often unsuccessful due to the "missing-middle" between entrepreneurs on one hand - who have good ideas but lack financing - and investors, on the other, who struggle to find lucrative investment opportunities. CTI PFAN carefully screens projects according to their potential for environmental and economic benefit, and for those selected offers hands on guidance and connection to potential investors (CTI PFAN, 2017).

The Nordic Development Fund (NDF) has since 2009 launched through its Nordic Climate Facility (NCF) six calls for proposal with the aim to promote small-scale (with NCF finance ranging between EUR 250,000-500,000 per project) climate and development projects in low-income countries (LICS) and lower middle-income countries (LMICs) with major upscaling potential. Strategically, NDF's focus is on being catalytic, supporting innovation and private sector development, project development and piloting of high-risk interventions. NDF's success in promoting innovative climate interventions has been acknowledged through numerous climate action awards (see UNFCCC, 2016 \& International Centre for Climate Governance [ICCG], n.d.). From the perspective of fossil fuel subsidy reform, the experiences gained through NCF projects can serve to highlight the critical importance of understanding the socioeconomic and cultural contexts on individual, project beneficiary and community levels. The socioeconomic incentives and livelihood benefits on local as well as national level must be thoroughly understood to secure support and sustainability for any energy (climatecompatible) transformation (Halonen et al., 2016). The NDF, supported through the five Nordic countries, while not currently working directly on fossil fuel subsidy reform, has a position paper on energy subsidies to guide grants in the energy sector. The position recognizes that "public subsidies to fossil fuels should be discouraged" but that "subsidies can be extended to level the playing field for clean energy (like solar, wind and geothermal)" if this approach fits with country policies (NDF, 2010).

\subsection{Why Switch Old Subsidies for New Subsidies?}

This is a valid question, and economists recognize that all subsidies distort markets and are subject to rent seeking and capture, as well as the political economy challenges of removing them once established. However, there is still a strong case for subsidizing renewables. Such policies are needed to incentivize investment in renewable over fossil fuel alternatives because of ongoing market failures to reflect the environmental and health costs, $\mathrm{CO}_{2}$ emissions and other pollutants associated with fossil fuels (IEA, 2016c). There are also other strong arguments for removing subsidies to incumbents (fossil fuels) and enabling them for new entrants (such as solar or energy service companies). It is also the case that in the IEA New Policies Scenario subsidies to renewables are expected to peak at USD 210 billion in 2030 before reducing thereafter. This is because strong $\mathrm{CO}_{2}$ prices (from a combination of fossil fuel subsidy reform and active carbon pricing or 
taxation) enable 40 per cent more generation from renewables without the need for subsidies to renewables (IEA, 2016c). Furthermore, the cost reduction in renewables means that this spending on subsidies directed toward them is also becoming more productive as each dollar of renewables subsidy delivers more capacity. The IEA (2016, p. 100) also suggests that as technological costs come down further - and electricity and $\mathrm{CO}_{2}$ prices increase - "more and more new renewable energy projects become economically competitive without any state support: in India, solar PV is competitive without subsidies well before 2030; for the world as a whole, most new renewables-based generation in 2040 does not require subsidies." Therefore, such SWAPs are not expected to be permanent in that sustainable energy technologies would become competitive - indeed recent auctions in Zambia suggest that they are competitive now (see below). SWAPs may also not need to represent all the savings from fossil fuel subsidy reform to nudge the economics of sustainable energy forward - a percentage of savings may be enough.

However, in the meantime high upfront costs are still a barrier to poor households accessing solar equipment and systems. Research also finds that when incentive schemes for renewables are removed, as in India, they can also lead to a steep reduction in new capacity additions (Sud, Sharma, Sharma \& Kitson, 2015). Institutional support and investment as in the Bangladesh Solar Home Scheme subsidy element, although small and declining, may also be important (Khandker et al., 2014).

\subsection{Potential Funders and International Support}

According to the OECD Development Assistance Committee's Creditor Reporting System database, Kreditanstalt für Wiederaufbau (KfW) is the single largest channel for all climate-related Official Development Aid (ODA) funding, with a 20 per cent share in 2014. Other main channels include Deutsche Gesellschaft für Internationale Zusammenarbeit (GIZ), United Nations Development Programme (UNDP), World Bank, UNEP, Food and Agriculture Organization of the United Nations (FAO), Danish International Development Agency (DANIDA), African Development Bank Group (AfDB), International Bank for Reconstruction and Development (IBRD), Asian Development Bank (ADB), United Nations Industrial Development Organization (UNIDO), World Food Program (WFP), International Fund for Agricultural Development (IFAD) as well as Development Finance Institutions (DFIs) (OECD CRS, 2016).

Based on a search of the OECD CRS database (OECD CRS, 2017) there have been a total of 22 climate-related ODA-funded (disbursed) projects during 2010 - 2015 aimed directly at fossil fuel subsidy reform. The relevant projects are distributed by donor according to Figure 11 and by channel in Figure 12. While these figures are interesting, they should be considered with some caution as they rely on the accuracy of data reported by the donor countries themselves in the CRS system and are linked only to climate change. For reference, four European countries (Germany, Norway, Sweden and Switzerland) announced in 2015 that they will allocate USD 500 million to the Transformative Carbon Asset Facility, which aims at large cuts in $\mathrm{CO}_{2}$ emissions in developing countries through policy actions (World Bank, 2015b). Nordic countries 
have also had both specific programs that focus on fossil fuel subsidy reform and broader programs like the Finnish Action program for development and taxation, which includes reform within its remit.

Even if the figures presented in Figure 11 are considered as indicative only, they reveal the overall mismatch between explicitly reported FFSR efforts (according to OECD CSR system amounting to USD 13.7 million across five years) compared to average annual subsidies during this period of around USD 500 billion. The misalignment between the scale of the issue and the level of the funding from governments to support other governments to handle subsidy reform is staggering, in that for every USD 1 dollar donors put toward climate-related research and capacity building on subsidy reform, over USD 180,000 is used by governments to subsidize fossil fuels. This mismatch, given the significant domestic financial and emissions savings that governments can potentially yield from undergoing such reforms, is extraordinary.

Figure 11: Climate-related ODA aimed at fossil fuel subsidy reform (by donor) disbursed during 2010-2015

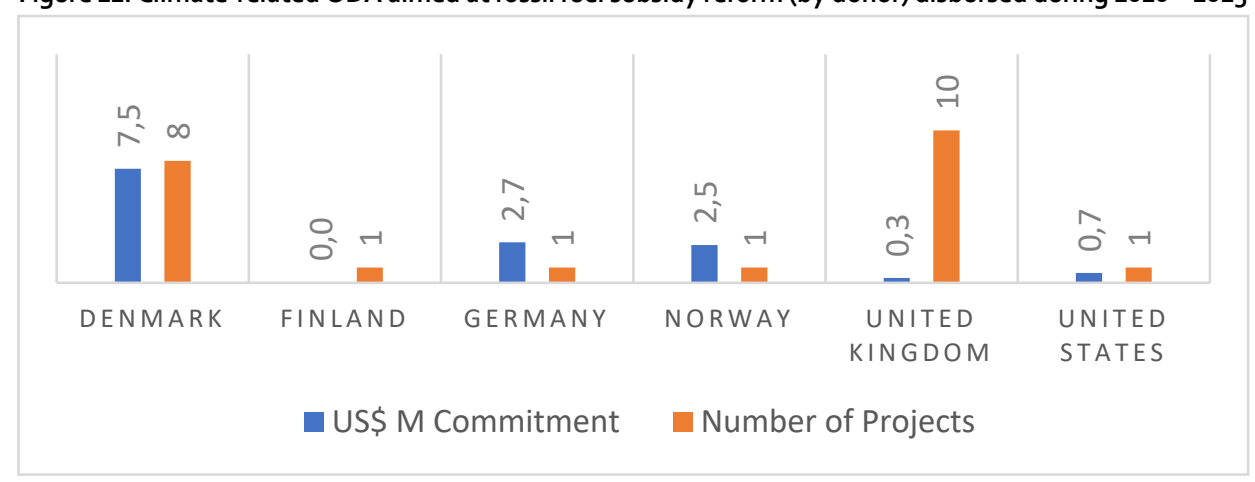

Figure 12: Climate-related ODA aimed at fossil fuel subsidy reform (by channel) during 2010 - 2015

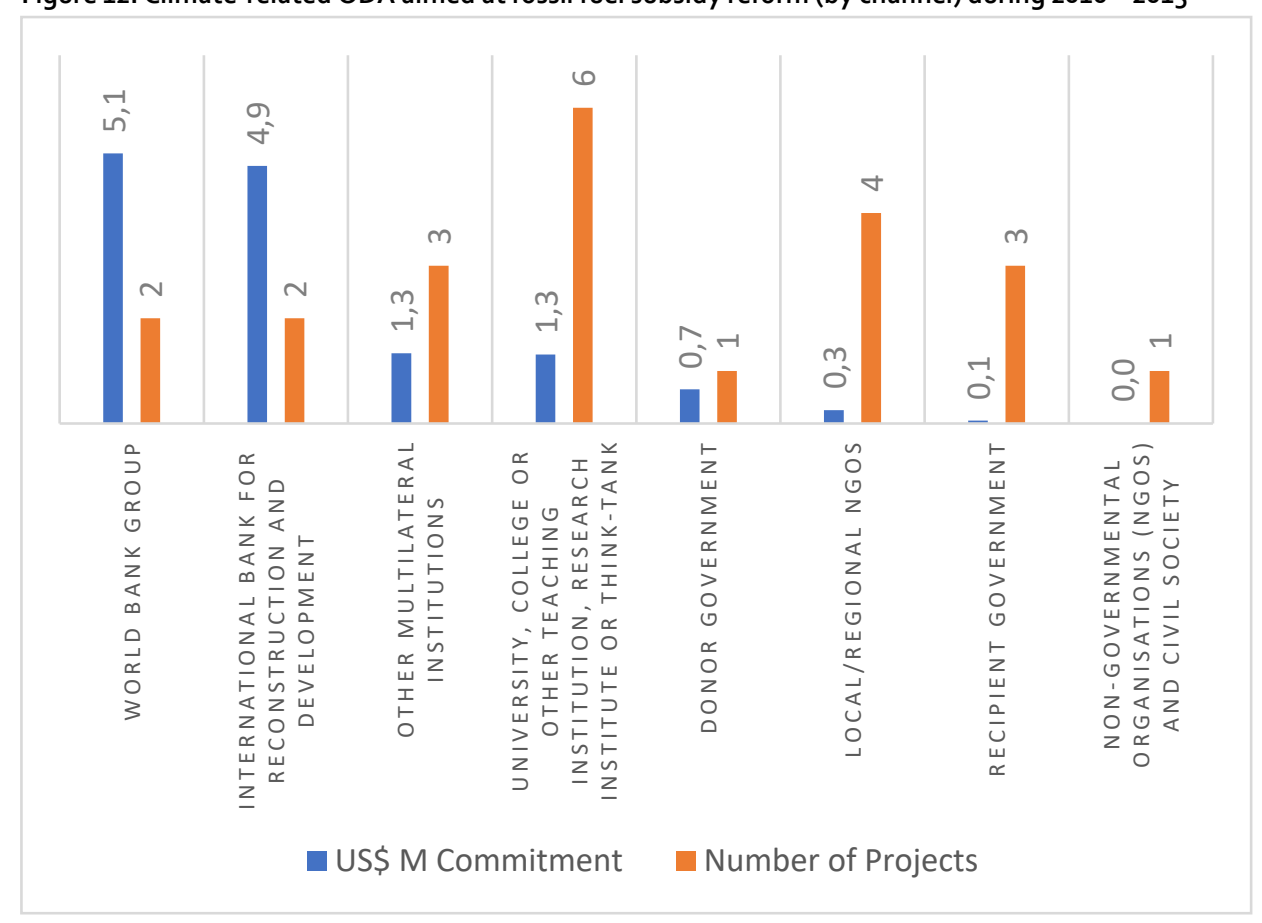




\section{Bangladesh}

\subsection{Energy Background}

Energy consumption has grown rapidly in Bangladesh over the past two decades, and the country faces a serious energy crisis due to inadequate energy resources. Average per capita consumption of energy is very low, at 160 kilograms of oil equivalent (kgoe), compared to $340 \mathrm{kgoe}$ in Nepal and $640 \mathrm{kgoe}$ in Asia more broadly (Planning Commission, 2011). Use of traditional fuels is high, and in 2010 Bangladesh had an electricity access deficit of 66.6 million people (or around 45 per cent of the 2010 population) (Bangladesh Bureau of Statistics [BBS], 2011a; Sustainable Energy for All, 2013). Progress has been made with the implementation of the Power System Master Plan (Ministry of Power, Energy and Mineral Resources [MPEMR], 2011), and the Ministry reports that there were 17.8 million consumers - or 74 per cent of the population - with access to electricity in 2015 (MPEMR, 2016). This implies a drop in electricity access deficit figures to 26 per cent of the population. However, many households rely heavily on kerosene, especially for lighting in rural households.

The number of people using biomass such as wood or dung for cooking stood at 134.9 million people in 2010 (or around 91 per cent of the 2010 population) (National Institute of Population Research and Training, 2009; Sustainable Energy for All, 2013). Use of solid fuels was much lower in urban areas (58.3 per cent) than in rural areas, where almost all households ( 96 per cent) use solid fuels (BBS, 2011b).

Bangladesh's onshore gas reserves are the primary source of its produced electricity. However, shrinking gas reserves have necessitated the import of crude oil and refined petroleum products. Currently, 46 per cent of the natural gas produced is used in the power and fertilizer sector. Natural gas is subsidized for power production, fertilizers and for end users in transport, industry and households. Oil products are also subsidized, which, together with increasing import dependence, presents a significant challenge for the government's finances. Up until 2010, natural gas accounted for 80 per cent of the electricity generated, but the generation mix began changing in 2012 due to surging demand. As of December 2016, natural gas accounts for 60 per cent of the electricity produced, while 30 per cent is obtained from furnace oil and diesel. The transportation sector is the largest consumer of petroleum products, with diesel accounting for 74 per cent of the consumption. Motor cars and auto rickshaws run on compressed natural gas (CNG), but trucks and buses continue to run on diesel. The agricultural sector also heavily relies on diesel for irrigation.

The Government of Bangladesh has set out a number of actions to change the energy mix in the Seventh Five Year Plan (2016-2020). These involve increasing gas exploration and establishing a gas allocation policy; setting up a coal import facility; and promoting the use of LPG in the domestic sector. With energy demand always 
outstripping supply, the government is also aiming to set up an "energy efficiency and conservation program," introducing financial incentives for improved cook stoves. It also targeting the development of an "energy subsidy policy" by FY 2017 at which point liquefied natural gas (LNG) imports may begin. Furthermore, the Plan assumes that the subsidy will be capped at 1 per cent of GDP and that "the subsidy will be targeted to the poor and for supporting the expansion of renewable energy programmes" (Planning Commission, 2015, p. 337).

\subsubsection{Fossil Fuel Subsidy Background}

In the past decade, due to poor pricing policies, state-owned energy enterprises have experienced long-term deficits that have been paid through subsidies. The recent fall in international oil prices has allowed the government to maintain a stable price level, and state-owned companies now operate at the breakeven point. However, there is no clear-cut policy for determining the oil price level, and an increase in international oil prices would lead to the reintroduction of subsidies. Due to dwindling developed reserves of natural gas, Bangladesh recently announced plans to increase natural gas prices by 22 per cent in 2017 (Rasel, 2015). Households use natural piped gas for cooking in cities, drivers use natural gas in vehicles for driving and industries utilize gas for generating electricity or for industrial processing (Bashar, 2016). The current price hike is being challenged in the courts.

In 2013 energy subsidies in Bangladesh stood at USD 4.5 billion, which is 3.2 per cent of GDP (IEA, 2014C) or almost USD 30 person. Subsidies apply to petroleum products (petrol, diesel and kerosene), natural gas and electricity. Bangladesh has used subsidies as a policy instrument for many years in agriculture, health, education, food and exports, as well as in the energy sector. While energy subsidies have been cited as important in facilitating energy access for the poor, they disproportionately benefit the wealthier sectors of society. Moreover, despite ongoing subsidies to gas and electricity, there are still serious deficits in access to electricity and non-solid fuel cooking fuels across Bangladesh. Indeed, Bangladesh is third in the world for the largest number of people without access to electricity (after India and Nigeria) and to non-solid fuels (after India and China) (Sustainable Energy for All, 2013) - see earlier Figure 3. 
Table 5: Fossil fuel subsidies in Bangladesh compared to subsidies for clean cooking technologies

\begin{tabular}{lllll}
\hline Fuel and year & $\begin{array}{l}\text { SUBSIDY } \\
\text { (\% GDP) }\end{array}$ & $\begin{array}{l}\text { SUBSIDY } \\
\text { (USD billion) }\end{array}$ & $\begin{array}{l}\text { COVERAGE } \\
\text { (million ppl) }\end{array}$ & $\begin{array}{l}\text { SUBSIDY } \\
\text { (USD/person) }\end{array}$ \\
$\begin{array}{l}\text { Total fossil fuel energy } \\
\text { subsidies 2013 }\end{array}$ & 3.2 & 4.5 & 39 & 39 \\
Biogas plant 2014-15 & 0 & 0.007 & 508 & 1 \\
$\begin{array}{l}\text { Improved cook stove } \\
\text { 2014-15 }\end{array}$ & 0 & 0.001 & & \\
Solar home system & & $\begin{array}{l}3 \text { million households } \\
\text { (10\% of off-grid } \\
\text { population) (2013) }\end{array}$ & 23 per unit (2013)
\end{tabular}

Source: Kitson et al. 2016.

\subsubsection{Carbon Emissions \& Fiscal Savings from Subsidy Removal}

The greatest impacts of fossil fuel subsidies in Bangladesh are linked to their opportunity costs. Revenues allocated to fossil fuel subsidies could rather be spent on developing national safety nets, strengthening health and education systems or on sustainable energy access and energy efficiency. At its height in 2012-13, the subsidy bill reached 2.8 per cent of GDP and accounted for 32 per cent of government revenue expenditure. This level of subsidy expenditure exceeded government spending on health and education combined (See Figure 2). The GSI-IF model when applied to Bangladesh found a reduction of 8.67 per cent of carbon dioxide equivalent emissions $\left(\mathrm{CO}_{2} \mathrm{e}\right)$ by 2020 against national BAU scenarios. With additional reductions from reallocation of revenues toward renewables and energy efficiency reductions reach 13.56 per cent in 2020. The larger impact of reallocation of savings toward renewables could potentially be the increase in households connected to solar home systems, farmers accessing solar pumps or a significant investment in energy efficiency within industry and the power sector.

\subsubsection{SWAP Projects}

Three options for SWAP projects within Bangladesh are identified here: a switch from diesel subsidies used for water pumping to solar pumps; a switch from gas subsidies toward fuel efficiency within the textile industry; and a shift from general fossil fuel subsidies toward a strengthened and consolidated national cash transfer system.

\subsubsection{SWAP Diesel Subsidies and Pumps for Solar Pumps}

Subsidized diesel is the largest refined petroleum product sold in the country. In 201516, 3,606,404 MT of diesel was sold by the Bangladesh Petroleum Corporation (BPC) (BPC, 2016), accounting for 69 per cent of the total petroleum sales. Of this, 25 per cent 
of the diesel was sold to the agricultural sector, while 54 per cent of the diesel sales were attributed to the transport sector making it the largest consumer of diesel in 2015-16 (Bangladesh Petroleum Corporation, 2016). Given the high consumption of subsidized diesel by these two sectors, one opportunity could be to swap diesel subsidies used for diesel-powered water pumps with solar-powered irrigation for the agriculture sector.

This SWAP would build on the efforts of the Sustainable and Renewable Energy Development Authority (SREDA) and the World Bank, who have developed a new scheme targeted at replacing diesel-powered pumps with solar pump sets (SREDA, 2017). A pilot to replace diesel irrigation pumps with 1,250 solar-powered pumps is planned (World Bank, 2017a). The SWAP project could include an assessment of this pilot and develop a business model to scale up distribution of pumps alongside phased reform of diesel subsidies with appropriate reallocation to this scheme. Total diesel sales to the agriculture sector in 2015-16 amounted to (approximately) USD 761 million. ${ }^{1}$ Even if a part of this is reduced and reinvested in helping farmers purchase solar pumps, it represents a significant reduction in repeated expenditure from the national budget.

A SWAP business model assumes that farmers' savings from reduced diesel expenditure can be channelled into partial payments of the solar pump. A group of farmers will have to come together to purchase a solar pump from a local partner organization. The latter must be willing to undertake a percentage of the project cost while the remaining comes from grant financing. Currently SREDA offers up to 50 per cent of the project cost as a loan at the rate of 6 per cent with a tenure of eight years. A formal business case with more details of isolating models to cover the shortfall in financing can be developed from the lessons of the World Bank pilot. IISD has experience in building such business models in India, where it supported swapping kerosene with solar home systems in a cluster of villages. This model is being further scaled with the help of parliamentarians in India. The SWAP model in Bangladesh can help develop this model to scale up deployment of solar pumps.

\subsubsection{SWAP Gas Subsidies for Improved Efficiency in the Textile Sector}

A SWAP could be implemented to enable the textile sector to invest in both renewable energy and improved energy efficiency. The sector is currently heavily reliant on gas for the majority of its power needs, which consumes 16 per cent of the gas used for power. The textile sector is a major contributor to Bangladesh's export income and supports millions of livelihoods. The recent gas price shortages and hikes have hit the sector hard, which makes the sector a priority candidate to consider swapping gas for renewable energy and improved energy efficiency.

Early in 2012 , GIZ conducted pilots to assess the potential of energy efficiency in the textile industry and found areas, like process machinery where rapid improvements could deliver huge energy savings $(G I Z, 2012)$. More recently, there is interest from the

1 As per BPC records, retail selling price of diesel was 65 Taka per litre (USD o.88 per litre). Total Diesel sale to the Agriculture sector in 2015-16 was 944,055 MT. 
International Finance Corporation (IFC) and the Bangladesh Bank in scoping out opportunities for renewable energy for the textile sector. IFC has launched a scoping study to assess the potential for rooftop solar PV and PV Hybrid solutions for captive power in the textile industry. To create an enabling environment, Bangladesh Bank has allocated USD 200 million to a green fund that will allow the textile sector to take lowcost loans and switch to more energy-efficient production (Daily Star, 2016). The SWAP might consider developing a financial model based on this past research, making it viable to switch to renewable energy or invest in energy-efficient technology that lowers energy consumption.

\subsubsection{SWAP Fossil Fuel Subsidies for Cash Transfer Safety Nets}

The SWAP would seek to reinforce Bangladeshi efforts to grow and improve social safety net schemes within the country with a focus on the extreme poor. There is a strengthened National Social Security Strategy (NSSS) that aims to lower poverty and vulnerability. The implementation of this program could be scaled up with an increase in funding from savings from removal of gasoline and diesel subsidies and an appropriate increase in safety nets targeting the very poor. 



\section{Indonesia}

\subsection{Energy Background}

Indonesia's energy mix and policy plans are influenced by the size of its population 250 million (World Bank, 2017b) as well as consistently high growth rates, particularly over the past 15 years (IEA, 2015). Economic success has been paired with rising living standards, population grown and urbanization. The national poverty level has also decreased from 23.4 per cent in 1999 to 11.25 per cent in 2014 .

There are challenges that come alongside this growth and development. First and foremost is that energy consumption has increased significantly over this same period. Electricity use has increased from roughly $40 \mathrm{TWh} /$ year in the early $1990 \mathrm{~s}$ to over 200 TWh/year by 2015 (Burke \& Kurniawati, 2016). Coupled with this is the ongoing challenge of delivering energy across a wide geographical area, including many remote areas where energy distribution can be difficult. Energy security and meeting energy demand growth are key challenges for energy policy in the country (IEA, 2015).

Overall, Indonesia is a net energy exporter, currently the largest coal exporter in the world, as well as one of the largest exporters of liquid biofuels and gas in the region (IEA, 2015). Despite this, Indonesia is also the second largest oil importer in the region.

The goal for the energy mix between now and 2050 is to grow the portion of new and renewable energy in the national mix, from 6 per cent in 2012 to 31 per cent in 2050. However, non-renewable fuels are still predicted to still provide a majority of energy with coal ( 25 per cent) gas ( 24 per cent) and oil (20 percent) all expected to remain key parts of the energy mix to mid-century (IEA, 2015).

\subsubsection{Fossil Fuel Subsidy Background}

Prior to recent reforms, electricity consumption subsidies climbed to above 100 trillion IDR (roughly USD 7.5 billion) in 2014 alone (Burke \& Kurniawati, 2016). A move to monthly automatic price adjustments as part of sector reform has reduced electricity subsidies significantly. IISD has also identified 15 production subsidies to Indonesia's coal industry totalling roughly IDR 8.5 trillion (USD 644 million) in 2014 (IISD, 2017).

On the transport side, the consumption of diesel and gasoline have been heavily influenced by historical subsidies for these fuels that kept their purchase prices below market rates. When reforms were eventually enacted, the resulting financial benefit was 211 trillion IDR (USD 15.6 billion) (Pradiptyo, et al., 2016).

Home heating fuels have also been subsidized. The government introduced a conversion program to encourage the shift from kerosene to cleaner burning LPG (the "Zero Kero Program") (Toft, Beaton, \& Lontoh, 2016). While this program led to significantly reduced use of kerosene, it also led to greatly increased use of LPG, and 
universal subsidies for $3 \mathrm{~kg}$ LPG canisters (5,000 IDR). This led to total subsidies for LPG climbing from 14.85 trillion IDR (USD 1.63 billion) in 2010 to 48.97 trillion IDR (USD 3.91 billion) in 2014 (Toft, Beaton, \& Lontoh, 2016). The government has since indicated that it will look to reform these LPG subsidies to better target the provision of energy access support for the poor, while those with the ability to do so will pay market rates. This could significantly reduce the economic cost of the LPG subsidy program. Reform is expected to occur over the course of 2017.

\subsubsection{Carbon Emissions \& Fiscal Savings from Subsidy Removal}

The GSI-IF model has been applied to Indonesia to assume a scenario where all fossil fuel subsidies are removed over the period of 2015-2020, looking at the impact this could have on national GHG emissions. This includes assessment of the impact on prices, the drop in demand for affected energy, and how cheaper fuel sources would be substituted. GSI also modelled a hypothetical 20 per cent savings related to energy efficiency resulting from fossil fuel subsidy reform and a 10 per cent investment in renewable energy. As highlighted in Table 6, the result of fossil fuel subsidy reform alone results in GHG savings of 6.97 per cent below BAU in 2020, while the inclusion of energy efficiency savings and renewable energy investment increase this figure to 12.14 per cent. In 2025, the total reduction of GHG emissions could reach as much as 19.28 per cent (GSI, 2015).

Table 6: Main results of the GIS-IF Model for Indonesia considering $\mathrm{CO}_{2}$ e emission reductions relative to the baseline (BAU) scenario from fossil fuel subsidy reform, EE (20 per cent of the subsidy saving) and RE (10 per cent of the subsidy saving) investments (\% reductions against BAU) (2015 figures)

\begin{tabular}{|c|c|c|c|c|c|c|c|c|c|c|}
\hline \multirow{3}{*}{ Indonesia } & \multirow{3}{*}{$\begin{array}{l}\text { Subsidy (USD) } \\
31,100,000,000\end{array}$} & \multirow{3}{*}{$\begin{array}{r}\text { Share of } \\
\text { GDP } \\
7.3 \%\end{array}$} & \multicolumn{2}{|c|}{$\begin{array}{r}\mathrm{CO}_{2} \text { e reduction } \\
\text { relative to } \mathrm{BAU} \\
\text { (FFSR) }\end{array}$} & \multicolumn{2}{|c|}{$\begin{array}{r}\mathrm{CO}_{2} \text { e reduction } \\
\text { relative to } \mathrm{BAU} \\
(\mathrm{EE} 20 \%)\end{array}$} & \multicolumn{2}{|c|}{$\begin{array}{r}\mathrm{CO}_{2} \text { e Reduction } \\
\text { relative to } \mathrm{BAU} \\
(\mathrm{RE} 10 \%)\end{array}$} & \multicolumn{2}{|c|}{$\begin{array}{r}\mathrm{CO}_{2} \text { reduction } \\
\text { relative to } \mathrm{BAU} \\
\text { (Total) }\end{array}$} \\
\hline & & & 2020 & 2025 & 2020 & 2025 & 2020 & 2025 & 2020 & 2025 \\
\hline & & & $-6.97 \%$ & $-6.19 \%$ & $-3.65 \%$ & $-8.84 \%$ & $-1.53 \%$ & $-4.25 \%$ & $-12.14 \%$ & $-19.28 \%$ \\
\hline
\end{tabular}

While it is difficult to quantify the financial impacts of subsidy reform, the Indonesia state budget process from 2015 offers an interesting window into the impact subsidy removal can have on a country. Roughly IDR 211 trillion (USD 15.6 billion) (Pradiptyo, et al., 2016), was originally allocated to fossil fuel subsidies for gasoline and diesel. Following the reforms, an amount totalling IDR 246 trillion was added to three areas including support for regions and villages, programming to boost growth and reduce poverty, and infrastructure.

\subsubsection{SWAP Project}

There are two swap ideas outlined here for consideration in Indonesia. The first is swapping LPG subsidies with increased focus and investment in social programming and infrastructure, following previous subsidy reform models in the country. The 
second idea is a newer one for Indonesia, but has the potential to shift the energy system fundamentally. This would include a swap of subsidies for coal electricity generation toward support for cleaner energy sources.

\subsection{Swapping LPG Subsidies for Increased Investments in the Social Safety Net}

Indonesia already has some experience in this area, through the work of the National Team for the Acceleration of Poverty Eradication ( $\mathrm{TNP}_{2} \mathrm{~K}$ ) and others that have focused on the benefits that cash transfers and social investments can have for broader poverty alleviation. Continued expansion of the social safety net can address existing poverty concerns as well as those that may emerge from ongoing reforms of the LPG fuel pricing system.

IISD is already undertaking an implementation design project and impact assessment of reform, working with partners like TNP2K and others. With the outputs and results of that project, a SWAP project could be used to measure the identified fiscal savings and impacts of reform. It would then feed them into a study of how revenue savings could be dedicated to lessening negative impacts and fostering investments in the social safety net responsive to the needs of Indonesians.

The total cost of LPG subsidies has increased significantly since the introduction of the current program: in 2014 the subsidies climbed to almost IDR 49 trillion (USD 3.91 billion) (Toft, Beaton, \& Lontoh, 2016). This represented 2.76 per cent of total state expenditures. Even if a portion of this subsidy is retained, the potential of a swap in the scale of multiple 10 of trillions of IDR can make a significant impact in the social safety net, even given the already robust safety net investments in Indonesia.

\subsubsection{Swapping Coal Production Subsidies for Renewable Energy Supports}

An existing barrier to the implementation of greater amounts of renewable energy in Indonesia is that the current, largely coal-fired, electricity generation system receive a number of subsidies and supports that mask the true cost of energy, and place renewable energy at a disadvantage. IISD has done preliminary analysis developing, for the first time, an inventory of coal subsidies that is as comprehensive as possible.

At the same time the government is in the process of reforming supports to the renewable energy sector, which, under the previous feed-in-tariff program, had difficulty incentivizing renewable energy investment.

A SWAP focused on shifting from coal to renewable power in Indonesia could utilize the existing coal support inventory as a starting point for the level of financial resources that could incentivize a shift to renewable energy. The SWAP could also include looking at new fiscal reform measures that could be developed and implemented to replace the existing feed-in-tariff system.

IISD has already identified over USD 600 million in support for coal electricity in 2015 alone. This is compared to roughly USD 130 million in support to renewables (IISD, 
2017). In addition, IISD quantified the cost of externalities of coal electricity (the impact on health and the environment) to be roughly equivalent to an additional charge of USD 9 cents per kWh (IISD, 2017). Reforming the support to the coal industry has the potential to open up significant investment streams for renewables, at the same time making them more competitive at a market level just by removing supports that keep coal prices low. Coupled with the estimated externality cost there is also the potential for health and environmental co-benefits from coal subsidy/support reform that make a further case for this SWAP.

\section{Potential Business Model for the SWAP}

The SWAP assumes that savings would stem from a reduction in LPG subsidies (which is already underway) or coal subsidies/support. Most of the LPG savings could be earmarked to assist in social programming for people who previously had access to subsidized LPG, but no longer do. In the second instance, savings from coal electricity support can be reinvested in a reformed renewable energy-support program. It is also anticipated that bilateral donor support might be established in recognition of the impact on GHG emissions of reduced coal electricity and the increased spending on renewable energy and low-carbon projects. Additionally, it could be possible to integrate a component in which the funding sought from international donors could be directly matched to the savings from subsidy removal.

For an LPG swap, given the process is already underway, a formal business case is not required, only an assessment of the impacts and business case for reinvestment, which would focus on social benefits and benefits of investments in the social safety net.

In the case of coal electricity reforms, more work will be needed to make the economic case for removing these supports and subsidies. This is where IISD's existing work on the cost of coal versus renewables is a good first step. This SWAP project would build on this work, particularly in two areas:

- Further discussion and refinement on the issue of externality costs associated with coal that have environmental and social impacts.

- The potential to drive down renewables costs through reforms and increased investments in clean energy technologies - at the same time that coal subsidies are removed - will provide a competitive advantage for renewables in the market. 


\section{Morocco}

\subsection{Current Energy Mix and Government Energy Plans}

Between 2000 and 2011, the IEA found that energy consumption in Morocco went up by 60 per cent. More than four fifths of the country's energy is generated with petroleum and coal. Electricity generated 16.5 per cent of the energy consumed in 2012, and served primarily the residential and general services sectors (IEA, 2014a).

The transformation of the energy sector is at the heart of Morocco's Nationally Determined Contribution (NDC), published in September of 2016 as part of its commitment under the UN Framework Convention on Climate Change (UNFCCC). Morocco's NDC (Morocco, 2016) builds on the National Energy Strategy and highlights the following energy-related goals:

- $\quad$ "Reaching over $52 \%$ of installed electricity production capacity from renewable sources by 2030.

- Reducing energy consumption by $15 \%$ by 2030 [by improving energy efficiency].

- Substantially reducing public fossil fuel subsidies, building on reforms already undertaken in recent years.

- Substantially increasing the use of natural gas, through infrastructure projects allowing liquefied natural gas imports."

\subsubsection{Fossil Fuel Subsidy Background}

The cost of subsidies across the economy is estimated to be equal to around 12.6 per cent of all government expenditures between 2005 and 2012, compared to 3.4 per cent in the period from 2001-2009 (Cour des Comptes, 2014). In 2012, petroleum products received the largest share of subsidies ( 85.7 per cent); comprised of diesel (39 per cent), gasoline ( 2 per cent), butane gas ( 28 per cent), industrial fuel ( 4 per cent), "normal" power generation fuel for ONEE (8 per cent) and "special" power generation fuel for ONEE (5 per cent). ${ }^{2}$

In January 2014, the government also removed subsidies to gasoline and industrial fuels and reduced subsidies to diesel according to a predefined timeline. In 2014, the total allocation was 41.65 billion DH of which 36.65 billion (USD 3.843 billion) was allocated to petroleum products. By December 2015 , the liberalization of all fuel prices was completed (Kingdom of Morocco, 2016a), with the exception of butane prices and 
the direct transfers to ONEE for electricity production. The latter are contractually set to expire by the end of 2017 (IMF, 2015).

Beginning in June 2016, butane subsidies have been reformed to remove some components, including import fees, that brought down the price share that the government is subsidizing from 70 per cent in 2012 to 45 per cent in late 2016 (Kingdom of Morocco, 2016b). There are talks of further liberalizing butane prices, although this has proven much more sensitive and politically challenging, as butane is widely used for cooking and heating.

Table 7: Fuel Subsidies in Morocco (in million USD)

\begin{tabular}{lrrrrrrrrr} 
& 2008 & 2009 & 2010 & 2011 & 2012 & 2013 & 2014 & 2015 & 2016 \\
Oil & 1,726 & 96 & 1,374 & 2883 & 3,030 & 2,214 & 1,020 & 0 & 0 \\
Butane & 1,123 & 660 & 1,197 & 1,579 & 1,895 & 1,824 & 1,200 & 772 & 665 \\
Electricity & 135 & 134 & 343 & 758 & 864 & 618 & 295 & 467 & 467 \\
Total (M USD) & 2,985 & 890 & 2,914 & 5,220 & 5,788 & 4656 & 2,515 & 1,239 & 1,132 \\
\hline
\end{tabular}

Source: See http://www.courdescomptes.ma/upload/MoDUle_20/File_20_118.pdf, http://cdc.gov.ma/wpcontent/uploads/UP/Statistiques/2016/12/RAPPORT-ACTIVITE-DECEMBRE-2016_FR.pdf and IMF, 2015.

\subsubsection{Carbon Emissions Reductions and Financial Savings from Subsidy Removal}

IISD has conducted a study to estimate the emission reductions resulting from a complete phase-out of fossil fuel subsidies in Morocco, including reductions of both past efforts and potential future policies (Gagnon-Lebrun \& Bassi, 2015). The study found that the subsidy reforms that have already been completed would bring about average GHG emission reductions of 6.6 per cent annually between 2012 and 2030 . The hypothetical phase-out of both butane and electricity subsidies to ONEE by 2020 would result in an additional 0.9 per cent in average annual reductions (approximately $2.8 \mathrm{Mt}$ $\mathrm{CO}_{2} \mathrm{e}$ ), for a total of annual average reductions of 7.5 per cent between 2012 and 2030 .

In January 2017, Morocco's Caisse de compensation estimated that butane subsidies for the year 2016 amounted to approximately USD 665 million $^{3}$ (Caisse de compensation, 2017). The Caisse de compensation notes in its 2017 report that approximately three fifths of butane subsidies benefit households (Caisse de compensation, 2017), who use the fuel both to heat their homes and cook (IEA, 2014a), with roughly two fifths going to the agriculture sector (approximately USD 260 million per year), where farmers use the resource mainly for water pumping and for heating purposes (Caisse de compensation, 2017).

3 Assumed exchange rate DH to USD in 2015 and 2016:0.0973. 
Morocco also spent an additional estimated USD 467 million in direct transfers to ONEE in 2016, through an agreement to mitigate the impact of subsidy removal running from 2014 to 2017 (IMF, 2015). The direct transfers to ONEE are set to expire in 2017. That said, ONEE is reported to have made losses every year since 2008 due to regulated tariffs below cost-recovery levels, which, as a publicly owned company, must eventually be covered by public funds (Cour des Comptes, 2014).

\subsubsection{SWAP Project - Butane to Solar Pumps}

This SWAP project aims to foster a switch from butane-powered irrigation systems to solar pump systems in the agricultural sector. The SWAP would consist in reforming butane subsidies to 1) level the playing field, which would result in solar pump systems becoming economically more attractive than other systems and 2) use the savings from the reform to create an investment environment that is conducive to the fast deployment of such systems in the agricultural sector.

The SWAP project aims to enable the implementation of a Nationally Appropriate Mitigation Action (NAMA) idea that has been developed by the AMEE (formerly ADEREE) (ADEREE, MEMEE \& UNEP, 2015), called the NAMA pompage solaire du Maroc, but that has faced challenges in implementation. The NAMA aims to deploy 30,000 solar pumps by 2030 in small farmers' operations (less than 5 hectares).

The program would meet three objectives: provide low-cost, easily accessible renewable energy to small farmers to irrigate their land; remove butane and diesel technologies that are not only more expensive, but that also have a more unpredictable price tag year-by-year, and considerable security risks and reduce Morocco's greenhouse gas emissions and help in achieving Morocco's NDC.

The deployment of the 30,000 solar pumps would result in an emission reduction estimated at 1.384 $\mathrm{MtCO}_{2}$ e over the period 2014-2030 (ADEREE, MEMEE \& UNEP, 2015).

\subsubsection{Potential Business Model}

Solar pump systems for irrigation appear to be already competitive in some situations. This means that even a progressive reform of butane subsidies may tip the balance in favour of solar pumps. With the foregoing in mind, two SWAP options could be envisaged.

Option 1: Considering the challenges related to reforms, Option 1 focusses on a EUR 3 million investment in support measures that entail awareness-raising campaigns, training for farmers and support to ensure repair and maintenance services are readily available nearby, to increase the number of farmers adopting solar pump systems. In that option, savings for the government would stem from a reduction in butane purchases from farmers making the switch and would be used to finance the initial support measures.

Option 2: Option 2 puts forth a SWAP project, in which the adoption of solar pumps is incentivized through a fast-track deployment program based on AMEE's NAMA. The financial incentives provided to farmers would be financed by the savings resulting from 
a significant reduction or a phase-out of butane subsidies. There are two options for the incentive scheme:

- Loans to farmers at a rate lowered by 2.5 per cent, specifically targeting farmers that are currently ineligible for agricultural credit (roughly half of the country's farmers) (ADEREE, MEMEE \& UNEP, 2015).

- After a number of years and perhaps only for some farmers, Morocco could add a subsidy element to the program once an initial phase would have resulted in financial savings. These could be allocated to subsidize the upfront investment that poorer farmers would have to make by 50 per cent.

The AMEE's NAMA suggests a subsidy of 50 per cent of the cost (up to a maximum of approximately USD 7,300 per farm) at a cost of USD 1,460 per hectare and installation kit (UNDP, 2016). Through such subsidies, it is estimated that the costs of solar pumps irrigation could be brought down to as much as USD $0.036 / \mathrm{m}^{3}$ on farms of 1 hectare or less, and USD $0.029 / \mathrm{m}^{3}$ on farms of between $1-5$ hectares (UNDP, 2016).

Farmers would be incentivized to make the switch to solar water pumps based on the favourable economic return of such an investment, resulting from both the increased cost of butane due to subsidy reforms and the incentives provided by the government to support the upfront investment.

It is assumed that both instruments combined would drastically speed up the transition and, again through the reduction of butane purchases, would result in financial savings for Morocco. Such programs could be implemented alongside targeted policies that ensure that most vulnerable groups do not suffer adverse impacts of reforming subsidies. This could take the form of assessing the actual energy use of subsidy beneficiaries, for example through energy bills. 


\section{Zambia}

\subsection{Energy system}

In 2014, final energy consumption in Zambia was approximately 100 TWh, the majority of which was derived from biomass (78 per cent), which is used for cooking by households and the industry, while hydro and imported oil represent an approximate share of 10 per cent each. Approximately 28 per cent of the population has access to electricity (RECP, 2017), of which around 97 per cent was generated from hydropower in 2014. In recent years, power shortages and lack of rainfall have driven declines in hydro-generation and increases in output and investment of fuel oil-based generators. To meet rising electricity demand, plans are underway to invest in a range of new options, including hydro, coal, wind and solar generation, and even nuclear power with emphasis on energy efficiency and climate change mitigation.

\subsubsection{Subsidies in Zambia}

Price reforms were enacted in 2013 to remove subsidies on transport fuels. The reforms led to rapid price rises - the cost of petrol increased by 21 per cent. Concerns have been raised that the inflationary impact of reforms has undermined affordability of essential commodities and has had significant impacts on the poorest groups in society (Consumer Unity and Trust Society [CUTS], 2013).

More recently, energy subsidies have again been under discussion. Zambia is reported to be in discussions with the IMF to reduce subsidies as part of broader economic reforms. In October 2016, it was reported that Zambia is planning to cut USD 1 billion of subsidies, including USD 600 million of subsidies to electricity and fuel (Reuters, 2016). Cuts of this magnitude will have a significant impact on the economy and require careful planning and design. Recent estimates from the IMF and the World Bank are shown in Table 8.

Table 8: Subsidy Estimates in Zambia

\begin{tabular}{|c|c|c|}
\hline Organisation & Period & Subsidy estimate \\
\hline $\begin{array}{l}\text { World Bank (World } \\
\text { Bank, 2016) }\end{array}$ & $\begin{array}{l}\text { September } 2015 \\
\text { and May } 2016\end{array}$ & $\begin{array}{l}\text { USD } 36 \text { million per month and electricity subsidies around USD } 26 \text { million } \\
\text { per month, costing a combined total of USD } 576 \text { million over the period } \\
\text { (World Bank, 2016). }\end{array}$ \\
\hline IMF (IMF, 2015) & 2015 & $\begin{array}{l}\text { USD } 2 \text { billion "pre-tax" subsidies to fossil fuel consumption. Under the IMF } \\
\text { definition, pre-tax subsidies exist where consumers pay prices below the } \\
\text { cost of supply. In addition, in } 2015 \text { there were a further USD } 340 \text { million of } \\
\text { "post-tax" subsidies with the majority (USD } 270 \text { million) being due to } \\
\text { foregone tax revenues. }\end{array}$ \\
\hline
\end{tabular}


The electricity sector still receives considerable subsidies. The cost of power purchase from independent power producers (IPPs) ranged from USD 7 cents per kWh to USD 15 cents per kWh while the average retail tariff was USD 6 cents per kWh. The mining industry consumes more than half of all the electricity consumed in Zambia $(6,245 \mathrm{GWh}$ out of a total of $11,449 \mathrm{GWh}$ ) and is therefore highly affected by power prices (Energy Regulation Board, 2015).

The main opportunity for subsidy reform appears to be the electricity sector. However, any reform must be sensitive to the importance of mitigating social impacts, ensuring that investments in sustainable energy technologies continue, and taking into account the significance of the mining sector in the Zambian economy. There is therefore a general migration toward cost-reflective tariffs on electricity by 2019 according to the Southern African Development Community (SADC) and petroleum products prices as evidenced by the November 2016 pronouncement of government disengagement in importation of petroleum products. In addition, international experience suggests that few governments are equipped to conduct commercial operations efficiently without resulting subsidies. Zambia is no exception, as globally it has relatively higher fuel prices - private sector involvement is hence expected to reduce the probability of the reintroduction of government subsidies.

\subsubsection{Potential Savings From Subsidy Reform}

Based on the estimates from the IMF, World Bank and the plans reported in the media, total energy subsidies are likely to be in the region of USD 300-600 million per year according to definitions that exclude the environmental externalities of subsidies. For comparison, the 2017 Zambian health budget was Kwacha (ZMW) 5.7 billion (approximately USD 600 million) and the social protection budget is ZMW 2.6 billion (USD 271 million).

In practice, there may well be good political and economic reasons that some portion of energy subsidies cannot be removed in the short term. In addition, to avoid negative impacts, subsidy reform would need to be accompanied by a comprehensive program of mitigation measures. Overall, it may be possible to realize savings of 50-70 per cent of current subsidy spending. 


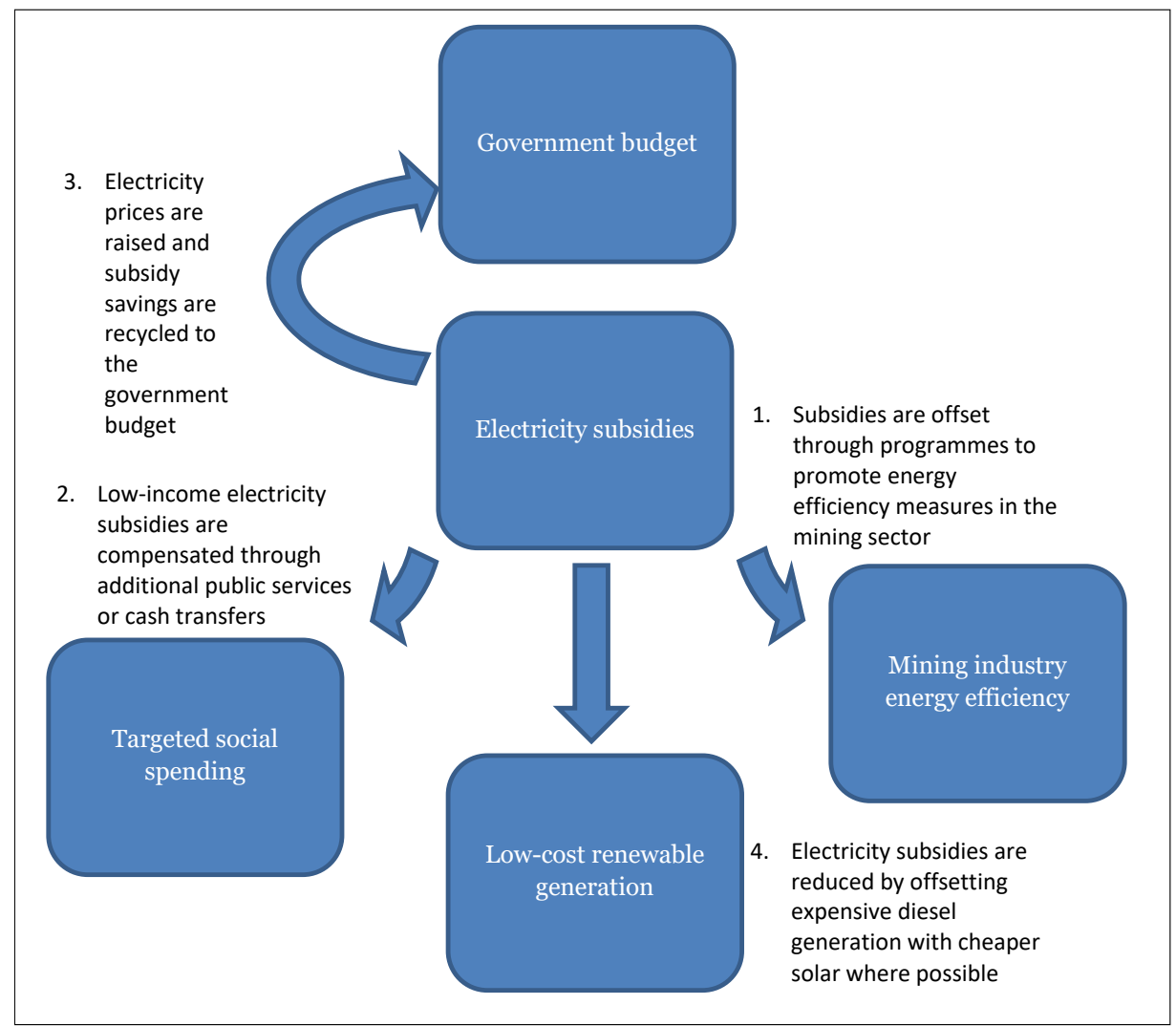

\subsubsection{The Subsidy Swap}

The fundamental idea of a subsidy swap project is to reform subsidies that drive fossil consumption and replace these with more sustainable alternatives. Improving environmental impacts and reducing the cost to the government. To address concerns over negative social impacts, subsidy reform plans typically include the development of a package of measures designed to provide targeted compensation to affected groups, promote sustainable energy to offset fossil fuel consumption and reduce demand though energy efficiency. Figure 13 shows a diagram designed to outline a possible swap configuration for Zambia.

\subsubsection{Swapping High-Cost Generation With Low-Cost Renewable Energy Generation}

The replacement of fossil-fuelled generation capacity with renewable energy offers the opportunity to save any subsidies that would have been spent promoting it. Recent solar auctions have shown that there is considerable potential for solar prices below the level of the highest-cost generators. The savings from offsetting other subsidies in the system should be built in to the decision-making process, allowing the provision of 
power purchase agreements to projects that reduce the overall cost of providing electricity.

The business model could be based around expanding the Scaling Solar initiative with funds from the subsidy reform supported by international donor funds. The first auction rounds of Scaling Solar for two 50 MW solar power projects ended in May 2016 with a price of USD 6.02 cents/kWh and USD 7.84 cents/kWh, which are the lowest solar prices in sub-Saharan Africa. The low prices achieved in the first round confirmed the competitiveness and efficiency of the Scaling Solar program and a second round with a projected $200 \mathrm{MW}$ of capacity is being prepared (IDC, 2016).

\subsubsection{Swapping Electricity Subsidies for Targeted Support}

A key barrier to the reform of electricity sector subsidies is the potential impacts on the lowest-income groups who stand to lose out most from the reforms. To address this barrier, targeted support could ensure that vulnerable groups are protected while prices are allowed to rise to meet the costs of operating the system. Targeted support measures could include the provision of direct cash transfers or public services specifically aimed at the affected groups.

The key criteria for development of targeted support measures is that they must be designed to deliver equal or better social outcomes but at a lower cost. Due to the inefficiency of fossil fuel subsidies as a welfare mechanism, this should be achievable at a much lower cost, freeing up additional funds for other purposes.

\subsubsection{Swapping Fossil Fuel Subsidies for Energy Efficiency Programs in the Mining Sector}

International competitiveness is a constant challenge for resource-dependent economies, which creates considerable pressure to hold down electricity prices to maintain competitiveness. Subsidized electricity prices in the mining sector are extremely costly and create disincentives to invest in energy-efficiency technologies that could reduce costs and promote competitiveness in the longer term.

A business model for an energy-efficiency scheme for the mining sector could be built around similar schemes that use revenues from carbon charges to promote increased efficiency (International Council on Mining and Metals [ICMM], 2013). These schemes increase costs to the mining industry but recirculate a portion of these costs to invest in measures that improve efficiency in the long term. 


\section{Way Forward}

This report has outlined the multidimensional impacts of fossil fuel subsidies. At their worst, subsidies can take up a significant part of government budgets and encourage rent seeking. Subsidies have been found to be consistently regressive in that they are a poor tool for delivering welfare benefits to the very poorest in society. Subsidies to fossil fuels represent huge lost opportunities in terms of alternative government investments into health, education, safety nets, and infrastructure. Removal of fossil fuel subsidies could have significant benefits for improving air quality in our cities. The presence of fossil fuel subsidies in the past has driven our global carbon emissions upwards, far higher than would have been the case without them.

Switching off subsidies to fossil fuel consumption is estimated to have emissions reductions ranging from between 6.4-8.2 per cent by 2050 (Schwanitz et al., 2014; Burniaux \& Chateau, 2014). Further switching off subsidies to producer subsidies could result in an additional $37 \mathrm{Gt}$ of savings by 2050 (Gerasimchuk et al., 2017). Reallocation of subsidy savings toward renewables and energy efficiency would lower emissions further still (from around 11 per cent to 18 per cent across 20 countries) (Merrill, Bassi, et al., 2015). Subsidy reform, combined with a strong - and fully implemented - climate agreement and regulation would improve emission reductions further (from 8 per cent without a cap to 10 per cent with a cap on emissions) (Burniaux \& Chateau, 2014). Finally, additional taxation of fossil fuels through VAT, GST or carbon pricing improves emission reductions further (to around 18.1-22.9 per cent) (Coady et al., 2015) and provides much-needed ongoing revenue streams to governments.

Opportunities for SWAPs abound, and are potentially available for all countries. This report has proposed SWAP outlines for Bangladesh, Indonesia, Morocco, and Zambia. Donor government support is needed to help build SWAPs in countries that want the support. Peer-to-peer support in terms of both capacity building and donor finance, from blocs like the Nordics, to work alongside reforming countries and enable a switch to sustainable energy would be welcome. Rich countries need to build SWAPs that shift the subsidies away from producers of coal, oil and gas toward renewables at home and toward building climate resilience abroad. Switching off fossil fuel subsidies alone would move us in the right direction for solving the climate change puzzle. A commensurate SWAP, and a switching on of investments and policies for sustainable energy systems would go even further. 



\section{Executive Summary (Nordic)}

För att skapa de energisystem och lösningar som möjliggör en dramatisk minskning av utsläpp av växthusgaser i enlighet med Parisavtalet, krävs bättre och smartare politiska beslut. Den här rapporten beskriver hur nuvarande subventioner för fossila bränslen globalt cirka USD 425 miljarder i 2015 - på flera olika sätt hindrar samhällen att uppnå de globala målen för hållbar utveckling.

Subventionerna representerar massiva resurser och missade möjligheter för regeringar att investera i implementering av Agenda 2030 målen - till exempel i hälsa och välbefinnande, utbildning, hållbar energi för alla, jämlikhet, och jämställdhet. Subventionerna försvårar uppnåendet av de globala målen även genom att accelerera klimatförändringen, då prisen för fossila bränslen hålls artificiellt låga, och ökar härmed konsumtion och utsläpp av växthusgaser. Enligt forskningsresultat kunde utfasningen av alla subventioner för fossila bränslen leda till en global 6.2-8.2 \% minskning av växthusgaser till år 2050. Kombinerat med andra fiskala instrument (dvs. utfasning av subventioner kombinerat med smartare beskattning) kunde en omfattande reform bidra till globala utsläppsminskningar på cirka $20 \%$.

Med utgångspunkt i existerande analys, identifierar denna rapport hur regeringar kunde avskaffa subventioner (switch off) för olja, gas och kol - och samtidigt - på ett smart sätt dirigera investeringar (switch on) till förnybara energikällor, energieffektivitet samt till andra produktiva ändamål (processen är ofta hänvisad till som en SWAP eller SWITCH). Nordiska länder har genomfört sådana synkroniserade reformer med utfasningen av fossila subventioner kombinerade till exempel med ökade stöd och investeringar i värmepumpar i Sverige, med ökade satsningar i elektriska bilar i Norge eller samtidiga systematiska satsningar i vindenergi i Danmark.

Omfattande internationellt potential kan identifieras till exempel in en utfasning av subventioner för diesel med samtidiga investeringar i solcellsdriven bevattning $i$ jordbruk; en utfasning av subventioner för gas med samtidiga investeringar i energieffektivisering inom industriproduktionen; en utfasning av subventioner för kol med samtidiga investeringar i förnybara energilösningar; eller en utfasning av subventioner för bensin med samtidiga satsningar i nationella sociala skyddsnätverk.

I denna rapport beskrivs pågående (SWAP/SWITCH) processer i Bangladesh, Indonesien, Zambia och Marocko. Motsvarande processer har även påbörjats $i$ Etiopien, Filippinerna och Peru. Rapporten inkluderar även förslag till möjliga SWAP i Kina och USA med fokus på nya satsningar i energieffektivitet. 



\section{References}

4C Maroc. (2015). Fiche résumé NAMA pompage solaire du Maroc. Retrieved from http://www.4c.ma/medias/fiche_resume_nama_pompage_solaire.pdf

Acar, S. \& Yeldan, E. (2016, March). Environmental impacts of coal subsidies in Turkey: A general equilibrium analysis. Energy Policy 90, 1-15.

https://doi.org/10.1016/j.enpol.2015.12.003

Adeoti, J.O., Chete, L., Beaton, C. \& Clarke, K. (2016). Compensation mechanisms for fuel subsidy removal in Nigeria. Winnipeg/Geneva: IISD/GSI.

http://www.iisd.org/sites/default/files/publications/compensation-mechanisms-fuel-subsidyremoval-nigeria.pdf

ADEREE, MEMEE \& UNEP. (2015). Fiche résumé NAMA pompage solaire du Maroc. Retrieved from http://www.4c.ma/medias/fiche_resume_nama_pompage_solaire.pdf

Anderson, K. \& McKibbin, W. J. (2000). Reducing coal subsidies and trade barriers: Their contribution to greenhouse gas abatement. Environment and Development, 5(), 457-81. https://doi.org/10.1017/S1355770Xoooo0279

Asia-Pacific Economic Cooperation (APEC). (2016). Leaders Declaration 2016. Retrieved from http://www.apec.org/Meeting-Papers/Leaders-Declarations/2016/2016_aelm.aspx

Asian Development Bank (ADB). (2015). Fossil fuel subsidies in Asia: Trends, impacts, and reforms integrative report. Retrieved from

http://www.adb.org/sites/default/files/publication/182255/fossil-fuel-subsidies-asia.pdf

Bangladesh Bureau of Statistics. (2011a). Bangladesh: Household income and expenditure survey, 2010. Retrieved from http://www-

wds.worldbank.org/external/default/WDSContentServer/WDSP/IB/2012

/07/12/000386194_20120712025531/Rendered/PDF/709500WPooPUBLoAndExpenditureSurve y.pdf

Bangladesh Bureau of Statistics. (2011b). Socioeconomic and demographic report, Population and Housing Census 2011. Retrieved from http://203.112.218.66/WebTestApplication/userfiles/Image/BBS/Socio_Economic.pdf

Bangladesh Petroleum Corporation. (2016). Sector wise sale of petroleum products during 201516. Retrieved from http://www.bpc.gov.bd/contactus.php?id=27

Bashar, R. (2015). Bangladesh cuts fuel price. bdnews24. http://bdnews24.com/economy/2016/04/24/bangladesh-cuts-fuel-oil-prices

Bast, E., Doukas, A., Pickard, S., van der Burg, L., \& Whitley, S. (2015). Empty promises: G20 subsidies to oil, gas and coal production. London/Washington DC: ODI/OCI. Retrieved from https://www.odi.org/publications/10058-empty-promises-g2o-subsidies-oil-gas-and-coalproduction

Bridle, R., \& Kitson, L. (2014). The impact of fossil fuel subsidies on renewable electricity generation. Winnipeg: Geneva: IISD/GSI. Retrieved from http://www.iisd.org/sites/default/files/publications/impact-fossil-fuel-subsidies-renewableelectricity-generation.pdf

Burke, P. J., \& Kurniawati, S. (2016). Electricity subsidy reform in Indonesia: Effects on electricity use. Canberra: Australian National University.

Burniaux, J. \& Chateau, J. (2011). Mitigation potential of removing fossil fuel subsidies: A general equilibrium assessment (OECD Economics Department Working Papers No. 853). Retrieved from http://dx.doi.org/10.1787/5kgdxijr2plp-en 
Burniaux, J. \& Chateau, J. (2014, December). Greenhouse gases mitigation potential and economic efficiency of phasing out fossil fuel subsidies. International Economics, 140, 71-88. http://dx.doi.org/10.1016/j.inteco.2014.05.002

Caisse de compensation. (2017, January). Rapport d'activité. Retrieved from https://cdc.gov.ma/wp-content/uploads/UP/Statistiques/2016/12/RAPPORT-ACTIVITEDECEMBRE-2016_FR.pdf

Clarke, K. (2014). Kerosene subsidies in India. Winnipeg/Geneva: IISD/GSI. Retrieved from https://www.iisd.org/GSI/sites/default/files/ffs_india_kerosene.pdf

Climate Technology Initiative Private Financing Advisory Network (CTI PFAN). (2017). Introduction to CTI PFAN. Retrieved from http://cti-pfan.net/about/\#a_about_us

Climate Vulnerable Forum CVF. (2016). Climate Vulnerable Forum Vision. Retrieved from http://www.thecvf.org/wp-content/uploads/2016/11/CVF-Vision-For-Adoption.pdf

Coady, D., Flamini, V., \& Sears, L. (2015). The unequal benefits of fuel subsidies revisited: Evidence for developing countries (IMF Working paper 15/250). Retrieved from http://www.imf.org/external/pubs/ft/wp/2015/wp15250.pdf

Coady, D., Parry, I., Sears, L., \& Shang, B. 2015. (2015). How large are global energy subsidies? (IMF Working Paper 15/105). IMF. Retrieved from https://www.imf.org/external/pubs/ft/wp/2015/wp15105.pdf

Commander, S. (2012). A guide to the political economy of reforming energy subsidies (IZA Policy Paper No. 52). Retrieved from http://ftp.iza.org/pp52.pdf

Consumer Unity and Trust Society (CUTS). (2013). Understanding the impact of the removal of fuel subsidies on the Zambian economy (Research Validation Meeting Report). Lusaka. Retrieved from http://www.cuts-international.org/arc/lusaka/lecop/pdf/reportvalidation_meeting-november22-2013.pdf

Cour des Comptes. (2014). Rapport sur Le système de compensation au Maroc Diagnostic et propositions de réforme. Kingdom of Morocco.

Daily Star. (2016, January). BB lines up \$20om green fund for textile, leather makers. Retrieved from http://www.thedailystar.net/business/bb-lines-20om-green-fund-textile-leather-makers201019

Danish Wind Industry Association. (2016, June 28). 2015 was a year of both ups and downs for the Danish wind industry. Retrieved from http://www.windpower.org/en/news/news.html\#747

Davis, L. W. (2013). The economic cost of global fuel subsidies. National Bureau of Economic Research. Retrieved from http://ideas.repec.org/p/nbr/nberwo/19736.html

Denjean, S., Su. T., Attwood, C., Bridle, R. and Gerasimchuk, I. (2016). Subsidies to coal-fired generation in China. Winnipeg/Geneva: IISD/GSI. Retrieved from https://www.iisd.org/sites/default/files/publications/subsidies-coal-power-generationchina.pdf

Deutsche Gesellschaft für Internationale Zusammenarbeit (GIZ). (2012). Promoting energy efficiency in the textile and garment industry. Retrieved from http://www.mdfbd.org/wpcontent/uploads/2012/08/GIZ.pdf

Durand-Lasserve, O., Campagnolo, L., Chateau, J., \& Dellink, R. (2015). Modelling of distributional impacts of energy subsidy reforms: An illustration with Indonesia (OECD Environment Working Paper, No. 86). OECD Publishing. http://dx.doi.org/10.1787/5js4koscrqq5-en

Ebeke, C., \& Ngouana, C.L. (2015). Energy subsidies and public social spending: Theory and evidence (IMF Working Paper 15/101). Retrieved from https://www.imf.org/external/pubs/ft/wp/2015/wp15101.pdf

Energimyndigheten. (2015). Värmepumparnas roll på uppvärmningsmarknaden. Utveckling och konkurrens i ett föränderligt energi-system. Retrieved from https://energimyndigheten.aw2m.se/FolderContents.mvc/Download?Resourceld=3044

Energy Regulation Board. (2015). Energy Sector Report 2015. Renewable Energy. Retrieved from http://www.erb.org.zm/reports/ESR2015.pdf 
Erickson, P., Down, A., Lazarus, M., Koplow, D., \& Track, E. (2017). Effect of government subsidies for upstream oil infrastructure on US oil production and global $\mathrm{CO}_{2}$ emissions. Seattle: Stockholm Environment Institute U.S. Center. Retrieved from https://www.seiinternational.org/mediamanager/documents/Publications/Climate/SEI-WP-2017-02-US-oiland-gas-production-subsidies.pdf

European Parliament. (2017). An integrated EU policy for the Arctic. Retrieved from http://www.europarl.europa.eu/sides/getDoc.do?pubRef=-//EP//NONSGML+TA+P8-TA-2017$0093+0+D O C+P D F+V o / / E N$

Finnish Ministry of Finance. (2016). Structural Policy Unit slides: Assessment and reform of fossil fuel subsidies in Finland.

Friends of Fossil Fuel Subsidy Reform. (n.d.). Fossil Fuel Subsidy Reform Communiqué. Retrieved from http://fffsr.org/communique/

Fullerton, D., Bruce, N., \& Gordon, S. (2008). Indoor air pollution from biomass fuel smoke is a major health concern in the developing world. Transactions of the Royal Society of Tropical Medicine and Hygiene, 102(9), 843-851. https://doi.org/10.1016/j.trstmh.2008.05.028

G7. (2016). G7 Ise-Shima Leaders' Declaration. Retrieved from http://www.mofa.go.jp/files/000160266.pdf

G20 (2016). G20 leaders' communiqué, Hangzhou summit, 4-5 September 2016. Retrieved from http://www.consilium.europa.eu/en/press/press-releases/2016/og/05-g20-leaderscommunique/

Gagnon-Lebrun, F., \& Bassi, A. (2015). Intégration de la décompensation dans l'INDC du Maroc. Winnipeg: IISD.

Gerasimchuk, I., Bassi, A. M., Ordonez, C. D., Doukas, A., Merrill, L., \& Whitley, S. (2017). Zombie energy: Climate benefits of ending subsidies to fossil fuel production. Geneva \& London: IISD \& ODI. Retrieved from http://www.iisd.org/library/zombie-energy-climate-benefitsending-subsidies-fossil-fuel-production

GETFiT. (2017). GETFiT Uganda Annual Report 2016. Retrieved from http://www.getfitreports.com/2016/

GETFiT-Uganda. (2016). GETFiT Performance Review and Baseline. Retrieved from http://www.getfit-uganda.org/downloads/

Global Financing Facility. (2017). Introduction. World Bank Group. Retrieved from https://www.globalfinancingfacility.org/introduction

Global Subsidies Initiative (GSI). (2015). Initial GSI-IF Model Outputs for Indonesia. Winnipeg: IISD.

Global Subsidies Initiative, International Energy Agency (IEA), World Bank, Organisation for Economic Co-operation and Development (OECD), \& International Monetary Fund (IMF). (2014). Comparison of fossil fuel subsidy support estimates. Retrieved from https://www.iisd.org/gsi/sites/default/files/ffs_methods_estimationcomparison.pdf Green Climate Fund (GCF). 2017. How to work with the private sector facility? Retrieved from https://www.greenclimate.fund/ventures/private-sector

Halonen, M., Illman, J., Klimscheffskij, M., Sjöblom, H., Rinne, P., Röser, F., Kurdziel, M-J., Höhne, N., Atteridge, A., \& Canales, N. (2016). Mobilizing climate finance flows in line with the Paris Agreement-Nordic Approaches and Opportunities. https://doi.org/10.6027/TN2017-519

Ibarrarán, M. E., Bassi, A.M, \& Boyd, R. (2015). Integrating SD + CGE models to assess green economy policies: Methods and application to Mexico.

Inchauste, V. \& Victor, D.G. (2017). The political economy of energy subsidy reform. Washington: World Bank. Retrieved from https://openknowledge.worldbank.org/handle/10986/26216

Integrated Research and Action for Development (IRADe). (2014). Evaluation of the scheme for kerosene-free Delhi. New Delhi: IRADe. Retrieved from http://irade.org/KFD\%2oReport_final.pdf

Intergovernmental Panel on Climate Change (IPCC). (2014). Climate Change 2014 Synthesis Report Summary for Policymakers. Retrieved from http://www.ipcc.ch/pdf/assessmentreport/ar5/syr/AR5_SYR_FINAL_SPM.pdf 
International Centre for Climate Governance (ICCG). (n.d.). Best climate practices. Retrieved from http://www.iccgov.org/en/observatories/best-climate-practices/

International Council on Mining and Metals (ICMM). (2013). The cost of carbon pricing: Competitiveness implications for the mining and metals industry. Retrieved from http://www.icmm.com/document/5286

International Energy Agency (IEA). (2013). IEA World Energy Outlook 2013. Retrieved from https://www.iea.org/publications/freepublications/publication/WEO2013.pdf

International Energy Agency. (2014a). Morocco 2014 energy policies beyond IEA countries.

Retrieved from http://www.iea.org/bookshop/482-Morocco_2014

International Energy Agency. (2014b). World energy outlook 2014. Retrieved from http://www.worldenergyoutlook.org/weo2014/

International Energy Agency. (2014C). Fossil fuel subsidies database 2014. Paris: IEA/OECD. Retrieved from

http://www.worldenergyoutlook.org/resources/energysubsidies/fossilfuelsubsidydatabase/

International Energy Agency. (2015a). Energy and climate change (World energy outlook special report). Paris: IEA. Retrieved from

https://www.iea.org/publications/freepublications/publication/WEO2015SpecialReportonEner gyandClimateChange.pdf

International Energy Agency. (2015b). World energy outlook 2015. Paris: IEA/OECD. Retrieved from http://www.worldenergyoutlook.org/we02015/

International Energy Agency. (2016a). Denmark electricity and heat.

International Energy Agency. (2016b). Global EV outlook 2016: Beyond one million electric cars. Retrieved from

https://www.iea.org/publications/freepublications/publication/Global_EV_Outlook_2016.pdf

International Energy Agency. (2016c) World energy outlook 2016. Paris: IEA/OECD. http://www.worldenergyoutlook.org/publications/weo-2016/

International Monetary Fund (IMF). (2012). Bangladesh gets $\$ 987$ million loan from IMF. Retrieved from https://www.imf.org/external/pubs/ft/survey/so/2012/CARo41112A.htm

International Institute for Sustainable Development (IISD). (2017). Subsidies to coal and renewables in Indonesia. Winnipeg: IISD.

International Monetary Fund. (2015a). IMF Survey: Counting the cost of energy subsidies. Retrieved from https://www.imf.org/external/pubs/ft/survey/so/2015/NEWo70215A.htm

International Monetary Fund. (2015b). Morocco: 2014 Article IV Consultation - Staff Report; Press Release; and Statement by the Executive Director for Morocco. Retrieved from

http://www.imf.org/external/pubs/ft/scr/2015/cr1544.pdf

International Renewable Energy Agency (IRENA). (2013). 30 years of policies for wind energy: Lessons from 12 wind energy markets. International Renewable Energy Agency. Retrieved from https://www.irena.org/DocumentDownloads/Publications/IRENA_GWEC_WindReport_Full.pdf

Khandker, S.R., Samad, H.A.; Sadeque, Z.K.M., Asaduzzaman, M, Yunus, M., \& Haque, A. K. E. (2014). Surge in solar-powered homes: Experience in off-grid rural Bangladesh. Washington, DC: World Bank Group. http://documents.worldbank.org/curated/en/871301468201262369/Surgein-solar-powered-homes-experience-in-off-grid-rural-Bangladesh

Kingdom of Morocco. (2016a). Projet de Loi de Finances pour l'année budgétaire 2017. Retrieved from https://www.finances.gov.ma/Docs/DB/2017/compens_fr.pdf

Kingdom of Morocco. (2016b). Projet de Loi de Finances pour l'année budgétaire 2017: Rapport sur la compensation. Retrieved from https://www. finances.gov.ma/Docs/DB/2017/compens_fr.pdf

Kitson, L., Merrill, L., Beaton, C., Sharma, S., McCarthy, A., Singh, C., Sharma, A., Parikh, J., Ohaeri, V.I., \& Chowdhury, T. T. (2016, August). Gender and fossil fuel subsidy reform: Current status of research. Winnipeg/Geneva: IISD/GSI. Retrieved from https://www.iisd.org/sites/default/files/publications/gender-fossil-fuel-subsidy-reformcurrent-status-research.pdf 
Lam, N. L., Smith, K. R., Gauthier, A., \& Bates, M. N. (2012). Kerosene: A review of household uses and their hazards in low-and middle-income countries. Journal of Toxicology and Environmental Health, Part B, Critical Reviews, 15(6), 396-432. Retrieved from http://www.ncbi.nlm.nih.gov/pubmed/22934567

Larsen, B. (1994). World fossil fuel subsidies and global carbon emissions in a model with interfuel substitution (Background Paper). Washington, DC: World Bank. Retrieved from http://documents.worldbank.org/curated/en/579011468765581746/pdf/multi-page.pdf

Larsen, B., \& Shaw, A. (1992). World fossil fuel subsidies and global carbon emissions (Background Paper No 25 for the World Development Report). Washington, DC: World Bank. Retrieved from http://documents.worldbank.org/curated/en/332991468739452719/pdf/multipage.pdf

Lin, B. \& Ouyang, X. (2014). A revisit of fossil-fuel subsidies in China: Challenges and opportunities for energy price reform. Energy Conversion and Management, 82, 124-134. Retrieved from http://dspace.xmu.edu.cn/handle/2288/90178

McGlade, C. \& Ekins, P. (2015, January 8 ). The geographical distribution of fossil fuels unused when limiting global warming to $2^{\circ} \mathrm{C}$. Nature, 517, 187-190. Retrieved from https://www.nature.com/nature/journal/v517/n7533/full/nature14016.html

Mendoza, M.N. (2014). Lessons learned: Fossil fuel subsidies and energy sector reform in the Philippines. Winnipeg/Geneva: IISD/GSI. Retrieved from

http://www.iisd.org/sites/default/files/publications/lessons-learned-ffs-energy-sector-reformphilippines.pdf

Merrill, L. (2014). Power, women and fossil-fuel subsidy reform in India. Winnipeg/Geneva: IISD/GSI. Retrieved from http://www.iisd.org/publications/power-gender-and-fossil-fuelsubsidy-reform-india

Merrill, L. (2016). Government subsidies to fossil fuels are 22 larger than those to government support on adaptation and climate change. Retrieved from https://www.iisd.org/gsi/news/government-subsidies-fossil-fuels-are-22-times-largergovernment-support-adaptation-climate

Merrill, L., Bassi, A.M., Bridle, R. \& Christensen, T.L. (2015). Tackling fossil fuel subsidies and climate change: Levelling the energy playing field. TEMANORD, Norden.

https://doi.org/10.6027/TN2015-575

Merrill, L., Christensen, T. Lasse, Sanchez, L., Tommila, P., Klimscheffskij, M. (2016). Learning from Leaders, Nordic and International Best Practice with Fossil Fuel Subsidy Reform. Copenhagen: Nordisk Ministerråd. https://doi.org/10.6027/ANP2016-778

Merrill, L., \& Chung, V. (2014). Financing the Sustainable Development Goals through fossil fuel subsidy reform: Opportunities in Southeast Asia, India and China. Winnipeg/Geneva: IISD/GSI. Retrieved from http://www.iisd.org/gsi/sites/default/files/financing-sdgs-fossil-fuel-subsidyreform-southeast-asian-india-china(6).pdf

Merrill, L. Harris, M., Casier, L., Bassi. M. A. (2015). Fossil-fuel subsidies and climate change: Options for policy-makers within their Intended Nationally Determined Contributions. GSI for the Nordic Council of Ministers, Norden. http://dx.doi.org/10.6027/NA2015-905

Ministry of Power, Energy and Mineral Resources. (2011). Power system master plan 2010. Retrieved from http://www.bpdb.gov.bd/download/PSMP/PSMP2010.pdf

Ministry of Power, Energy and Mineral Resources. (2016). Power sector at a glance, October 2015. Bangladesh. Retrieved from http://www.powercell.gov.bd/site/page/d73ofg8d-891247a2-8a35-382c4935eddc/Power-Sector-at-a-Glance

Morocco (2016). Morocco - Nationally Determined Contribution under the UNFCCC. Retrieved from http://www4.unfccc.int/ndcregistry/PublishedDocuments/Morocco\%2oFirst/Morocco\%20First\% 20NDC-English.pdf

Muttitt, G. (2016). The sky's limit. Why the Paris Climate Goals require a managed decline of fossil fuel production. Washington, DC: Oil Change International. Retrieved from http://priceofoil.org/2016/og/22/the-skys-limit-report/ 
National Institute of Population Research and Training. (2009). Bangladesh demographic and health survey 2007. Retrieved from http://dhsprogram.com/pubs/pdf/FR207/FR207\%5BApril10-2009\%5D.pdf

Norden, (2012). Nordic Environmental Action Plan 2013-2018. Retrieved from https://doi.org/10.6027/ANP2012-766

Nordic Development Fund. (2010). Nordic Development Fund position paper on energy subsidies.

Oil Change International (OCI). (2016). G20 Fossil Fuel Subsidies Sign On Statement Implementation of $\mathrm{G}_{20}$ Commitment to Phase Out Fossil Fuel Subsidies. Retrieved from http://priceofoil.org/content/uploads/2016/06/G20-Fossil-Fuel-Subsidies-Sign-On.pdf

Ogarenko, I., \& Hubacek, K. (2013) Eliminating indirect energy subsidies in Ukraine: Estimation of environmental and socioeconomic effects using input-output modeling. Journal of Economic Structures, 2(7),

Organisation for Economic Co-operation and Development (OECD). (2015). OECD Companion to the Inventory of Support Measures for Fossil Fuels 2015. Paris: OECD Publishing. DOI: http://dx.doi.org/10.1787/9789264239616-en

Organisation for Economic Co-operation and Development. (2016). "Description of the ENVLinkages model." In The Economic Consequences of Outdoor Air Pollution, OECD Publishing, Paris. DOI: http://dx.doi.org/10.1787/9789264257474-9-en

OECD CRS. (2016). OECD Creditor Reporting System database. Retrieved from https://stats.oecd.org/Index.aspx?DataSetCode=CRS1

Overseas Development Institute (ODI). (2017). Statement: G20 governments must lead in phasing out subsidies and public finance for fossil fuels - to accelerate green investment and reduce climate risk. Retrieved from https://www.odi.org/sites/odi.org.uk/files/downloads/statement_g2o_governments_must_lea d_in_phasing_out_subsidies_and_public_finance_for_fossil_fuels_7_mar_2017.pdf

Parry, I., Heine, D., Lis, E., \& Li, S. (2014). Getting energy prices right: From principle to practice. Washington, DC: IMF.

Planning Commission. (2011). Sixth five year plan FY2011 - FY2015. Dhaka, Bangladesh: Ministry of Planning. Retrieved from https://www.unicef.org/bangladesh/Six-Five-Year-Plan-2012Final.pdf

Planning Commission. (2015) Seventh Five Year plan: Accelerating growth Empowering Citizens FY2016-FY2020. Retrieved from http://www.Iged.gov.bd/UploadedDocument/UnitPublication/1/322/11.\%207th\%2oFive\%20Y ear\%2oPlan(Final\%2oDraft).pdf

Pradiptyo, P., Susamto, A., Wirotomo, A., Adisasmita, A., \& Beaton, C. (2016). Financing development with fossil fuel subsidies. Winnipeg: IISD. Retrieved from https://www.iisd.org/sites/default/files/publications/financing-development-with-fossil-fuelsubsidies-indonesia.pdf

Rasel, A.R. (2017). Taka 300 hike in household gas price in two phases. Dhaka Tribune. Retrieved from http://www.dhakatribune.com/bangladesh/power-energy/2017/02/23/gas-price-goingafternoon/

RECP. (2017). Governmental Framework | RECP. Retrieved from https://www.africa-eurenewables.org/market-information/zambia/governmental-framework/

Reuters. (2016). Zambia tells IMF will cut $\$ 1$ billion in subsidies. Retrieved from http://af.reuters.com/article/investingNews/idAFKCN12AoK7

Ross, M. L., Hazlett, C. \& Mahdavi, P. (2017). Global progress and backsliding on gasoline taxes and subsidies. Nature Energy, 2(1). https://doi.org/10.1038/nenergy.2016.201

Sawyer, D. \& Stiebert, S. (2010). Fossil fuels: At what cost? Government support for upstream oil activities in three Canadian provinces: Alberta, Saskatchewan, and Newfoundland and Labrador. Winnipeg/Geneva: IISD/GSI. Retrieved from http://www.iisd.org/library/fossil-fuels-what-costgovernment-support-upstream-oil-activities-three-canadian-provinces 
Schwanitz, V.J., Piontek, F., Bertram, C., \& Luderer, G. (2014). Long-term climate policy implications of phasing out fossil fuel subsidies, Energy Policy, 67, $882-894$.

https://doi.org/10.1016/j.enpol.2013.12.015

Sharma, S. (2014). Subsidies to liquefied petroleum gas in India: An assessment of the direct benefit transfer in Mysore. Winnipeg/Geneva: IISD/GSI. Retrieved from https://www.iisd.org/gsi/sites/default/files/ffs_india_lpg_mysore.pdf

Stefanski, R. (2016). Into the mire: A closer look at fossil fuel subsidies. Calgary: Calgary School of Public Policy. Retrieved from http://www.policyschool.ca/authors/stefanski-radoslaw

Sud T., Sharma R., Sharma R., \& Kitson, L. (2015). India's Accelerated Depreciation Policy for wind energy. Winnipeg/Geneva: IISD/GSI. Retrieved from

https://www.iisd.org/sites/default/files/publications/india-accelerated-depreciation-policywind-energy-case-study.pdf

Sulistiowati, Erika (2015, Dec. 11). The impact of fossil fuel subsidies on growth. Economics of Development (ECD). Retrieved from https://thesis.eur.nl/pub/33406/

Sustainable Energy for All. (2013). Global tracking framework. Washington, DC: ESMAP and IEA. Retrieved from https://openknowledge.worldbank.org/handle/10986/16537

Sustainable Energy for All. (2015). Scaling Up Finance For Sustainable Energy Investments (SEI Report of the SE4all Advisory Board Finance Committee). Retrieved from http://www.se4all.org/sites/default/files/l/2015/og/SE4All-Advisory-Board-FinanceCommittee-Report.pdf

Sustainable and Renewable Energy Development Authority (SREDA). (2017). IDCOLS RE financing Scheme and Programs. Retrieved from http://www.sreda.gov.bd/index.php/site/page/86b6-e5ff-o3fb-28o8-dc7a-obfg-egc1-75b7gdeb-f4od

Terton, A., Gass, P., Merrill, L., Wagner, A., \& Meyer, E. (2015). Fiscal Instruments in INDCs: How countries are looking to fiscal policies to support INDC implementation. Winnipeg/Geneva: IISD/GSI. Retrieved from https://www.iisd.org/sites/default/files/publications/fiscalinstruments-indcs.pdf

Toft, L., Beaton, C., \& Lontoh, L. (2016). International experiences with LPG subsidy reform. Winnipeg: IISD. Retrieved from http://www.iisd.org/sites/default/files/publications/international-experiences-with-LPGsubsidy-reform.pdf

U.K. Government. (2016). Climate finance roadmap to US $\$ 100$ billion. Retrieved from https://www.gov.uk/government/publications/climate-finance-roadmap-to-us1oo-billion

United Nations. (2015) Addis Ababa Action Agenda of the Third International Conference on Financing for Development (Addis Ababa Action Agenda). Retrieved from http://www.un.org/ga/search/view_doc.asp?symbol=A/RES/69/313

United Nations Development Programme (UNDP). (2016). Morocco: Promoting the development of photovoltaic pumping systems for irrigation.

United Nations Educational, Scientific and Cultural Organization (UNESCO). (2015). Education for All Global monitoring report (Policy Paper 18). (http://unesdoc.unesco.org/images/0023/002321/232197E.pdf

United Nations Environment Programme (UNEP). (2016). The Adaptation Gap Finance Report. Retrieved from http://drustage.unep.org/adaptationgapreport/sites/unep.org.adaptationgapreport/files/docu ments/agr2016.pdf

United Nations Framework Convention on Climate Change (UNFCCC). (2016). Winners of 2016 UNFCCC Momentum for Change Award Announced. Retrieved from https://momentum.unfccc.int/res/p/lighthouse-activities/

UNSTATS. (2016). Report of the Inter-Agency and Expert Group on Sustainable Development Goal Indicators (E/CN.3/2016/2/Rev.1) https://unstats.un.org/sdgs/indicators/Official\%2oList\%200f\%2oProposed\%20SDG\%2olndica tors.pdf 
van Asselt, H., Merrill, L. \& Kulovesi, K. (2017, March 17). Fossil fuel subsidies and the global climate regime. Retrieved from https://ssrn.com/abstract $=2934919$

Vidal, J. (2015). The rise of diesel in Europe: the impact on health and pollution. The Guardian. Retrieved from https://www.theguardian.com/environment/2015/sep/22/the-rise-diesel-ineurope-impact-on-health-pollution

World Bank. (2015a, April 9). Closing the USD 70 billion climate financing gap. Retrieved from http://www.worldbank.org/en/news/feature/2015/04/og/closing-the-climate-finance-gap

World Bank. (2015b). New $\$ 500$ million initiative to boost large-scale climate action in developing countries. Retrieved from http://www.worldbank.org/en/news/press-release/2015/11/30/new500-million-initiative-to-boost-large-scale-climate-action-in-developing-countries

World Bank. (2016). Zambia economic brief beating the slowdown: Making every Kwacha count. Retrieved from

http://documents.worldbank.org/curated/en/804591467989562427/pdf/106508-WP-P157243PUBLIC.pdf

World Bank. (2017a). Rural Electrification and Renewable Energy Development II (RERED II) Project (P131263). Retrieved from http://documents.worldbank.org/curated/en/341351488209549741/pdf/ISR-DisclosableP131263-02-27-2017-1488209538492.pdf

World Bank. (2017b). World Development Indicators. Retrieved from http://databank.worldbank.org/data/reports.aspx?Code=SP.POP.TOTL\&id=af3ce82b\&report_ name=Popular_indicators\&populartype=series\&ispopular=y

World Health Organization (WHO). (2016a). Ambient (outdoor) air quality and health. Retrieved from http://www.who.int/mediacentre/factsheets/fs313/en/

World Health Organization. (2016b). Children's environmental health: Air Pollution. Retrieved from http://www.who.int/ceh/risks/cehair/en/

World Trade Organization. (n.d.). World Trade Organization Agreement on Subsidies and Countervailing Measures (WTO ASCM), Article 1.1 https://www.wto.org/english/docs_e/legal_e/24-scm.pdf

Xue, H., Wand, H., Bridle, R., Gerasimchuk, I., \& Attwood, C. (2015). Subsidies to coal production in China. Retrieved from https://www.iisd.org/sites/default/files/publications/subsidies-coal-production-in-china.pdf

Zhou, P. P., Lloyd, P., Mzezewa, C., Kipondya, F., Asamoah, J., \& Simonsen, H. (2009). Determination of regional emission factors for the power sector in Southern Africa. Journal of Energy in Southern Africa, 20(4), 11-18. 


\section{Annexes}

\section{Annex 1. Comparison of Global Figures for Fossil Fuel Subsidies Estimates}

Figure 14: Fossil Fuel Subsidies Estimates

\begin{tabular}{|c|c|c|c|c|}
\hline \multicolumn{2}{|r|}{ OECD ${ }^{i}$} & IEA $\mathbf{A i}^{\mathrm{i}}$ & \multicolumn{2}{|r|}{ GSIiv } \\
\hline \multicolumn{5}{|c|}{ Headline Estimate: } \\
\hline $\begin{array}{c}\text { Estimate } \\
\text { (US\$ billion; dates) }\end{array}$ & \begin{tabular}{|c}
$\mathbf{5 5 - 9 0}$ \\
(Annually during 2005-2011)
\end{tabular} & $\begin{array}{c}544 \\
(2012)\end{array}$ & 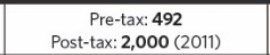 & $\begin{array}{l}\text { Country and sector } \\
\text { specific }\end{array}$ \\
\hline Reference & $\begin{array}{c}\text { Inventory of Estimated Budgetary } \\
\text { Support and Tax Expenditures } \\
\text { for Fossil Fuels }\end{array}$ & World Energy Outlook 2013 & $\begin{array}{l}\text { Energy Subsidy Reform - } \\
\text { Lessons and Implications }\end{array}$ & $\begin{array}{c}\text { Various: } \\
\text { www.iisd.org/gsi }\end{array}$ \\
\hline \multicolumn{5}{|c|}{ Coverage - countries: } \\
\hline Countries included & 34 OECD member countries ${ }^{v}$ & $\begin{array}{l}40 \text { countries, primarily } \\
\text { emerging and developing }\end{array}$ & 176 countries & Study dependent \\
\hline \multicolumn{5}{|c|}{ Coverage - energy carriers: } \\
\hline Petroleum products & $\checkmark$ & $a^{n}$ & $\checkmark 176$ countries $^{\text {nI }}$ & $\checkmark$ \\
\hline \begin{tabular}{|c|} 
Coal \\
\end{tabular} & $\checkmark$ & $\checkmark$ & $\sqrt{56}$ countries & $\checkmark$ \\
\hline Natural gas & $\checkmark$ & $\checkmark$ & $\sqrt{56}$ countries & $\checkmark$ \\
\hline Electricity ${ }^{\text {vil }}$ & $\begin{array}{l}x \text { (unless exclusively } \\
\text { fossil-fuel generated) }\end{array}$ & $\begin{array}{c}\checkmark \text { (non-fossil power subsidies } \\
\text { excluded) }\end{array}$ & $\checkmark 77$ countries & $\checkmark$ \\
\hline \multicolumn{5}{|c|}{ Coverage - subsidy and support incidence: } \\
\hline Producer & $\begin{array}{l}\checkmark \text { (including General Services } \\
\text { Support Estimates, GSSE) }\end{array}$ & $x$ & $\begin{array}{l}\checkmark \text { (including OECD Producer } \\
\text { Support estimates, excluding } \\
\text { GSSE) }\end{array}$ & $\begin{array}{c}\checkmark \\
\text { For specific countries }\end{array}$ \\
\hline Consumer & $\checkmark$ & $\checkmark$ & $\checkmark$ & $\checkmark$ \\
\hline \multicolumn{5}{|c|}{ What is included within the benchmark against which subsidies or support are estimated: } \\
\hline $\begin{array}{c}\text { Fossil-fuel } \\
\text { reference prices }\end{array}$ & International price & $\begin{array}{c}\text { International prices } \\
\text { (in country average cost prices) }\end{array}$ & $\begin{array}{c}\text { International price or cost- } \\
\text { recovery price in the case of } \\
\text { electricity }\end{array}$ & International price \\
\hline $\begin{array}{l}\text { Consumption- } \\
\text { based taxes }\end{array}$ & $\begin{array}{c}\checkmark \text { VAT (Value-added Tax) or } \\
\text { GST (Goods and Service Tax), } \\
\text { excise }\end{array}$ & $\checkmark$ VAT or GST & $\begin{array}{c}\times \text { Pre-tax } \\
\checkmark \text { Post-tax: VAT actual and } \\
\text { estimated (at regional rate) }\end{array}$ & $\checkmark$ VAT or GST, excise \\
\hline $\begin{array}{c}\text { Non-internalized } \\
\text { negative } \\
\text { externalities }\end{array}$ & $\begin{array}{l}\text { x (includes exemption of } \\
\text { applied carbon taxes) }\end{array}$ & $x$ & $\begin{array}{c}x \text { Pre-tax } \\
\checkmark \text { Post-tax: various }\end{array}$ & $\begin{array}{c}x \text { (non-application } \\
\text { of environmental } \\
\text { legislation) }\end{array}$ \\
\hline \multicolumn{5}{|c|}{ Methods for defining and measuring subsidies and support: } \\
\hline Definition & $\begin{array}{l}\text { Government, producer } \\
\text { and consumer support } \\
\text { mechanisms. }\end{array}$ & $\begin{array}{l}\text { Government actions that result in } \\
\text { prices paid by end users below the full } \\
\text { cost of supply (based on international } \\
\text { benchmarks). }\end{array}$ & $\begin{array}{l}\text { Pre-tax: price paid by consumers } \\
\text { below a benchmark price, } \\
\text { producers above the benchmark. } \\
\text { Post tax: pre-tax plus taxes below } \\
\text { efficient levels. }\end{array}$ & $\begin{array}{l}\text { World Trade } \\
\text { Organization Agreement } \\
\text { on Subsidies and } \\
\text { Countervailing Measures } \\
\text { (WTO ASCM), Article } 1.1\end{array}$ \\
\hline Method & $\begin{array}{l}\text { Inventory approach. Two } \\
\text { thirds of subsidy mechanisms } \\
\text { currently identified are } \\
\text { preferential tax treatment. }\end{array}$ & $\begin{array}{l}\text { Price-gap (fuels); average cost plus } \\
\text { transport \& distribution, capped at cost } \\
\text { of a combined cycle gas turbine power } \\
\text { plant (power). }\end{array}$ & $\begin{array}{l}\text { (i) Price-gap approach for } \\
\text { consumer subsidies and (ii) } \\
\text { inventory approach for producer } \\
\text { subsidies. }\end{array}$ & $\begin{array}{l}\text { Inventory approach. } \\
\text { WTO ASCM interpreted } \\
\text { as around } 30 \text { energy } \\
\text { subsidy types. }\end{array}$ \\
\hline Data sources & $\begin{array}{l}\text { Based on official government } \\
\text { data, with inputs from experts. }\end{array}$ & $\begin{array}{l}\text { IEA and secondary data sources, and } \\
\text { an annual survey identifying countries } \\
\text { that set energy prices below the full } \\
\text { cost of supply. }\end{array}$ & $\begin{array}{l}\text { Based on IMF, IEA, and OECD } \\
\text { data. Wider sources for post-tax } \\
\text { estimates. }\end{array}$ & $\begin{array}{l}\text { Official data as far as } \\
\text { possible. In-country } \\
\text { research with experts. }\end{array}$ \\
\hline $\begin{array}{l}\text { Units of } \\
\text { measurement } \\
\text { (country data) }\end{array}$ & $\begin{array}{l}\text { Reported by country currency, } \\
\text { line by line for each subsidy } \\
\text { item }\end{array}$ & $\begin{array}{l}\text { Average subsidization rate (as a } \\
\text { proportion of the full cost of supply) } \\
\% \text { USD\$/person } \\
\% \text { share of GDP USD \$ by fuel type }\end{array}$ & $\begin{array}{l}\% \text { of government revenue } \\
\% \text { of GDP by country and region }\end{array}$ & $\begin{array}{l}\text { Country total in US\$ } \\
\text { and national currency }\end{array}$ \\
\hline
\end{tabular}

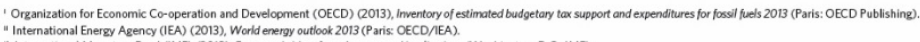

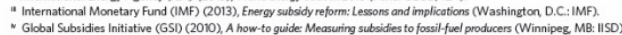

"Global Subsidies Initiative (GSI) (2010), A how-to guide Measuring subsidicy
"Work is underway to expand coverage to major energing economies.

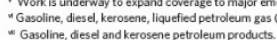

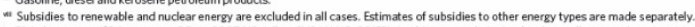

Note: This table was based on data available in 2014. Since then, research from the IMF revised the global estimate upwards to 4.9 trillion annually for 2013 (Coady et al., 2015).

Source: GSI, IEA, WB, OECD and IMF, 2014 


\section{Annex 2. Likely Impacts on Poor Women of Fossil Fuel Subsidies, Their Reform and Mitigation Measures}

Figure 15: Likely Impacts on Poor Women of Fossil Fuel Subsidies

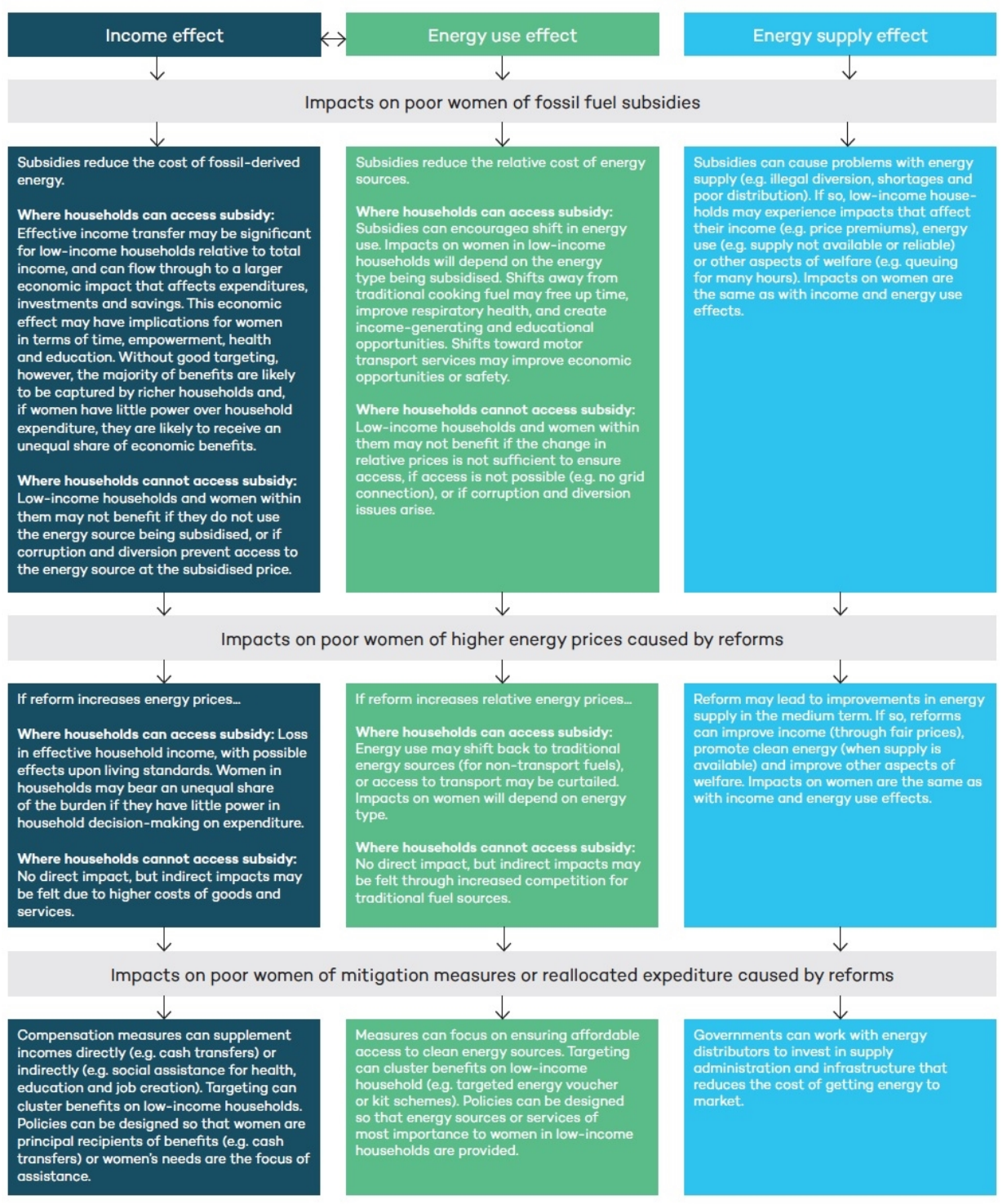

Source: Kitson et al., 2016. 


\section{Annex 3. Emissions Reductions Scenarios from Removal of Fossil Fuel Subsidies, existing research}

Table 9: Emissions Reductions Scenarios from Removal of Fossil Fuel Subsidies, existing research

\begin{tabular}{l|l|l} 
Name Scope Description & Emissions Reduction Methodology
\end{tabular}

Global Studies

Larsen, Global

1994
$9 \%$ reduction globally assuming no change in the oil price and a $5 \%$ reduction globally assuming a change in the oil price from removal of USD 230 billion of subsidies. An equivalent reduction in carbon emissions could be achieved by an OECD carbon tax of in the order of USD 50-90 dollars per tonne. (Larsen and Shaw, 1992). A 7\% reduction in emissions from removal of USD 2010 billion subsidies, accounting for interfuel substitution. Reduction of national carbon emissions by more than $20 \%$ relative to the baseline emissions in some countries (Larsen, 1994).

Coady, Global

Parry, removal

Sears, \& with

Shang, appropri

2015 ate

(IMF) taxation

IEA Global

2013 partial

and removal

2015 by 2030

Burniau

$x \&$

Chatea

U, 2014,

Table 2,

p. 83

Durand-

Lasserv

e et al.,

2015
A $18.1-22.9 \%$ decrease in carbon dioxide emissions based on global removal of consumer pre and post tax fossil fuel subsidies (Coady, Parry, Sears, \& Shang, 2015)

A 10 per cent reduction in energy sector emissions by 2030, from accelerating the (partial) phase-out of subsidies to fossil fuel consumption (part of the IEA's Bridge Scenario, which also includes energy efficiency [49 per cent], limiting construction and use of least-efficient coal-fired plants [9 per cent], minimizing methane emissions from upstream oil and gas production [ 15 per cent] and renewables investment [17\%]) (IEA, 2015b). FFSR moderating the growth in demand as well as supporting energy efficiency, and the only end user price considered in this scenario of energy sector measures: "Accelerated action towards a partial phase-out of fossil-fuel subsidies would reduce $\mathrm{CO}_{2}$ emissions by $360 \mathrm{Mt}$ in 2020" (IEA, 2013, p. $81)$.

An 8 per cent reduction in global GHG emissions of $6.1 \mathrm{Gt}$ of carbon dioxide (by 2050) from a countrie staggered removal of consumer fossil fuel s and Korea and Mexico subsidies based on 2008 subsidy figures (including an emissions cap on OECD countries and Brazil increases the reduction to 10 per cent) (Burniaux \& Chateau, 2014)

"[The] multilateral phase-out of energy consumption subsidies leads to $3 \%$ global GHG emission reduction at horizon 2020 relative to the baseline" (Durand-Lasserve, et al., 2015, p.53). For a description of the OECD EnvironmentalLinkages Model see OECD (2016) p.101-105.

$5-9 \%$ and $7 \%$

$$
18.1-22.9 \%
$$

$0 \%$ by 2030 (energy sector emissions only). $360 \mathrm{Mt}$ in 2020.
8.2 per cent by 2050 or $6.1 \mathrm{Gt}, 2.5$ per cent by 2020

$3 \%$ by 2020
IMF model for $\mathrm{CO}_{2}, \mathrm{SO}_{2}$ and local pollutants emissions reductions

World Energy Model
OECD ENV-Linkages General Equilibrium model

OECD ENV-Linkages General Equilibrium model 
Schwan Global The report confirms "the short-term benefits of itz et phasing out fossil fuel subsidies as found in prior al., 2014

Stefans $\mathrm{ki}, 2014$

Anders

on \&

Global coal

McKibbi

n, 1997

Gerasi

mchuk

et al.,

2017

studies. However, these benefits are only sustainable to a small extent in the long term if $50.6 \mathrm{Gt}$ (0.6\%) in the $\mathrm{G}_{20}$ phase-out scenario to 2020 scenario" (p. 886).

Global $\quad 20.7 \%$ lower global carbon emissions between 1980 and 2010 if countries had not subsidized 2010 without fossil fuel subsidies. (Stefanski, 2014).

An 8 per cent reduction in carbon dioxide emissions from a phase-out of coal subsidies OECD countries (Anderson \& McKibbin, 1997).

Global producer fossil fuel production globally would reduce the dedicated climate policies are weak or non-existent" (Schwanitz et al, 2014, p.882). "Over the whole time frame, until 2100 the cumulative savings range from $220.8 \mathrm{Gt}(2.7 \%)$ in the scenario Zero2020" (p.886). "A $6.4 \%$ reduction of global emissions in the Zero fossil fuels (2014). 36 per cent lower emissions in (production and consumption) in OECD and nonResearch finds a complete removal of subsidies to subsidies world's emissions by $37 \mathrm{Gt}$ of $\mathrm{CO}_{2}$ over 2017-2050

\section{Specific Country Studies}

Merrill, Average Average of $11 \%$ in 2020 from across 20 countries Bassi et of 11 per (country (as a \% of national emissions reductions): al., cent in 2015 2020 from 20 countrie $\mathrm{s}$, total of 2.82 $\mathrm{Gt}$ of $\mathrm{CO}_{2}$ equivale nt Algeria (22\%), Bangladesh (9\%), China (1\%), Egypt (15\%), Ghana (3\%), India (3\%), Indonesia (7\%), Iran (18\%), Iraq (41\%), Morocco (2\%), Nigeria (2\%), Pakistan (3\%), Russia (6\%), Saudi Arabia (30\%), Sri Lanka (2\%), Tunisia (6\%), UAE (14\%), US (0.2\%), Venezuela (34\%), and Vietnam (2\%)). This average across 20 countries rises to 18 per cent by 2020 with modest recycling of saved revenues toward renewables (10 per cent) and energy efficiency (20 per cent). Average annual government savings of USD 93 per tonne of $\mathrm{CO}_{2}$ abated. (Merrill, Bassi et al., 2015)

Various Country China, a 3.72 per cent carbon dioxide reduction specific between 2006 and 2010 (Lin \& Ouyang, 2014); India: $1.3-1.8 \%$, Indonesia: $5.1-9.3 \%$, Thailand: $2.8 \%$ by 2030 (ADB, 2015); Indonesia 7.9-8.3\% 2020 (Durrand-Lasserve et al. 2015); Ukraine, 3.6 per cent reduction or 15 million tonnes of $\mathrm{CO} 2 \mathrm{e}$ (Ogarenko \& Hubacek, 2013); Mexico, 34 million tonnes of CO2e saved every year between 2014 2035 from a mix of Green Growth transport measures including FFSR giving a NPV of USD 193,300 million between that period (Ibarrarán, Bassi, \& Boyd, 2015); Turkey, elimination of production subsidies to coal leads to $2.5 \%$ reduction in $\mathrm{CO} 2$ e by 2030 and removal of regional investment subsidies to $5.4 \%$ reductions (Acar and Yelden, 2016).
$0.6-2.7 \%$ by 2100 depending on the scenario.

In 2010 a world without subsidies would have had carbon emissions $36 \%$ lower than they actually were.

$8 \%$

$37 \mathrm{Gt}$ of $\mathrm{CO}_{2}$ over 20172050

Average of $11 \%$ in 2020 from 20 countries, total of $2.82 \mathrm{Gt}$ of $\mathrm{CO}_{2}$ equivalent
REMIND (intertemporal energy-economy model)
Backward-looking emission intensities

GSI-IF (p)

GSI-Integrated Fiscal model (GSI-IF) 


\begin{tabular}{|c|c|c|c|c|}
\hline $\begin{array}{l}\text { Sawyer } \\
\& \\
\text { Stiebert } \\
(2010)\end{array}$ & $\begin{array}{l}\text { Canada } \\
\text { producer } \\
\text { subsidies }\end{array}$ & $\begin{array}{l}\text { Sawyer \& Stiebert ( } 2010 \text { ) estimated that the } \\
\text { removal of subsidies to upstream oil and gas in } \\
\text { Canada would reduce oil production in three } \\
\text { Canadian provinces by } 5 \% \text { between } 2011 \text { and } \\
2020 \text {, and would decrease Canada's emissions by } \\
2 \% \text { ( } 10 \% \text { in oil sands). }\end{array}$ & $\begin{array}{l}5 \% \text { across three } \\
\text { Canadian provinces } \\
\text { between } 2011 \text { and } \\
2020\end{array}$ & CGE model \\
\hline $\begin{array}{l}\text { Erickso } \\
\text { n et al. } \\
(2017)\end{array}$ & $\begin{array}{l}\text { US } \\
\text { producer } \\
\text { subsidies }\end{array}$ & $\begin{array}{l}\text { Erickson et al. (2017) show that at USD } 50 \text { per } \\
\text { barrel, roughly the January } 2017 \text { oil price, } 45 \% \text { of } \\
\text { discovered (but not yet producing) U.S. oil would } \\
\text { depend on subsidies to reach minimum returns } \\
\text { acceptable to investors. The additional oil } \\
\text { produced due to subsidies would emit } 8 \text { billion } \\
\text { tonnes of } \mathrm{CO}_{2} \text {. }\end{array}$ & $\begin{array}{l}8 \text { billion tonnes of } \mathrm{CO}_{2} \\
\text { released due to } \\
\text { subsidies unlocking } \\
\text { otherwise } \\
\text { uneconomically viable } \\
\text { reserves. }\end{array}$ & \\
\hline
\end{tabular}

Source: This report. Updated, corrected and based on Merrill and Casier (2015) and Merrill, Bassi et al., (2015). Unless otherwise stated these assessments cover consumer subsidies only. 
Nordic Council of Ministers

Ved Stranden 18

DK-1061 Copenhagen K

www.norden.org

\section{Making the Switch}

This report estimates fossil fuel subsidies to be around USD 425 billion.

Such subsidies represent large lost opportunities for governments to invest in renewable energy, energy efficiency and sustainable development. Removal of subsidies can lead to carbon emission reductions ( 6 to 8 per cent by 2050 globally), Reductions that can be improved further with a switch or a 'SWAP' towards sustainable energy. This report describes the scale and impact of fossil fuel subsidies on sustainable development. It describes the SWAP concept to switch savings made from fossil fuel subsidy reform, towards sustainable energy, energy efficiency and safety nets. The report provides potential SWAP outlines for Bangladesh, Indonesia, Morocco and Zambia. 'Making the Switch' was written for the Nordic Council Ministers by the Global Subsidies Initiative of IISD and Gaia Consulting. 